\title{
Global carbon budget 2014
}

C. Le Quéré ${ }^{1}$, R. Moriarty ${ }^{1}$, R. M. Andrew ${ }^{2}$, G. P. Peters ${ }^{2}$, P. Ciais ${ }^{3}$, P. Friedlingstein ${ }^{4}$, S. D. Jones ${ }^{1}$,

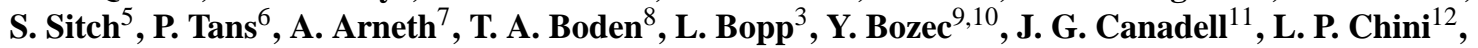
F. Chevallier ${ }^{3}$, C. E. Cosca ${ }^{13}$, I. Harris ${ }^{14}$, M. Hoppema ${ }^{15}$, R. A. Houghton ${ }^{16}$, J. I. House ${ }^{17}$, A. K. Jain ${ }^{18}$, T. Johannessen ${ }^{19,20}$, E. Kato ${ }^{21,22}$, R. F. Keeling ${ }^{23}$, V. Kitidis ${ }^{24}$, K. Klein Goldewijk ${ }^{25}$, C. Koven ${ }^{26}$,

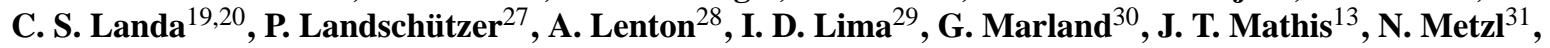
Y. Nojiri ${ }^{21}$, A. Olsen ${ }^{19,20}$, T. Ono ${ }^{32}$, S. Peng ${ }^{3}$, W. Peters ${ }^{33}$, B. Pfeil ${ }^{19,20}$, B. Poulter ${ }^{34}$, M. R. Raupach ${ }^{35, \dagger}$, P. Regnier ${ }^{36}$, C. Rödenbeck ${ }^{37}$, S. Saito ${ }^{38}$, J. E. Salisbury ${ }^{39}$, U. Schuster ${ }^{5}$, J. Schwinger ${ }^{19,20}$, R. Séférian ${ }^{40}$, J. Segschneider ${ }^{41}$, T. Steinhoff ${ }^{42}$, B. D. Stocker ${ }^{43,44}$, A. J. Sutton ${ }^{45,13}$, T. Takahashi ${ }^{46}$, B. Tilbrook ${ }^{47}$, G. R. van der Werf ${ }^{48}$, N. Viovy ${ }^{3}$, Y.-P. Wang ${ }^{49}$, R. Wanninkhof ${ }^{50}$, A. Wiltshire ${ }^{51}$, and N. Zeng ${ }^{52}$

${ }^{1}$ Tyndall Centre for Climate Change Research, University of East Anglia, Norwich Research Park, Norwich NR4 7TJ, UK

${ }^{2}$ Center for International Climate and Environmental Research - Oslo (CICERO), Oslo, Norway

${ }^{3}$ Laboratoire des Sciences du Climat et de l'Environnement, Institut Pierre-Simon Laplace, CEA-CNRS-UVSQ, CE Orme des Merisiers, 91191 Gif sur Yvette Cedex, France

${ }^{4}$ College of Engineering, Mathematics and Physical Sciences, University of Exeter, Exeter EX4 4QF, UK

${ }^{5}$ College of Life and Environmental Sciences, University of Exeter, Exeter EX4 4QE, UK

${ }^{6}$ National Oceanic \& Atmospheric Administration, Earth System Research Laboratory (NOAA/ESRL), Boulder, CO 80305, USA

${ }^{7}$ Karlsruhe Institute of Technology, Institute of Meteorology and Climate Research/Atmospheric Environmental Research, 82467 Garmisch-Partenkirchen, Germany

${ }^{8}$ Carbon Dioxide Information Analysis Center (CDIAC), Oak Ridge National Laboratory, Oak Ridge, TN, USA

${ }^{9}$ CNRS, UMR7144, Equipe Chimie Marine, Station Biologique de Roscoff, Place Georges Teissier, 29680 Roscoff, France

${ }^{10}$ Sorbonne Universités (UPMC, Univ Paris 06), UMR7144, Adaptation et Diversité en Milieu Marin, Station Biologique de Roscoff, 29680 Roscoff, France

${ }^{11}$ Global Carbon Project, CSIRO Oceans and Atmosphere Flagship, GPO Box 3023, Canberra, ACT 2601, Australia

${ }^{12}$ Department of Geographical Sciences, University of Maryland, College Park, MD 20742, USA

${ }^{13}$ National Oceanic \& Atmospheric Administration/Pacific Marine Environmental Laboratory (NOAA/PMEL), 7600 Sand Point Way NE, Seattle, WA 98115, USA

${ }^{14}$ Climatic Research Unit, University of East Anglia, Norwich Research Park, Norwich NR4 7TJ, UK

${ }^{15}$ Alfred Wegener Institute Helmholtz Centre for Polar and Marine Research, Postfach 120161, 27515 Bremerhaven, Germany

${ }^{16}$ Woods Hole Research Center (WHRC), Falmouth, MA 02540, USA

${ }^{17}$ Cabot Institute, Department of Geography, University of Bristol, Bristol BS8 1TH, UK

${ }^{18}$ Department of Atmospheric Sciences, University of Illinois, Urbana, IL 61821, USA

${ }^{19}$ Geophysical Institute, University of Bergen, Allégaten 70, 5007 Bergen, Norway

${ }^{20}$ Bjerknes Centre for Climate Research, Allégaten 55, 5007 Bergen, Norway

${ }^{21}$ Center for Global Environmental Research, National Institute for Environmental Studies (NIES), 16-2 Onogawa, Tsukuba, Ibaraki 305-8506, Japan

${ }^{22}$ Institute of Applied Energy (IAE), Minato-ku, Tokyo 105-0003, Japan

${ }^{23}$ University of California, San Diego, Scripps Institution of Oceanography, La Jolla, CA 92093-0244, USA

${ }^{24}$ Plymouth Marine Laboratory, Prospect Place, Plymouth PL1 3DH, UK 
${ }^{25}$ PBL Netherlands Environmental Assessment Agency, The Hague/Bilthoven and Utrecht University, Utrecht, the Netherlands

${ }^{26}$ Earth Sciences Division, Lawrence Berkeley National Lab, 1 Cyclotron Road, Berkeley, CA 94720, USA

${ }^{27}$ Environmental Physics Group, Institute of Biogeochemistry and Pollutant Dynamics, ETH Zürich, Universitätstrasse 16, 8092 Zurich, Switzerland

${ }^{28}$ CSIRO Oceans and Atmosphere Flagship, P.O. Box 1538 Hobart, Tasmania, Australia

${ }^{29}$ Woods Hole Oceanographic Institution (WHOI), Woods Hole, MA 02543, USA

${ }^{30}$ Research Institute for Environment, Energy, and Economics, Appalachian State University, Boone, NC 28608, USA

${ }^{31}$ Sorbonne Universités (UPMC, Univ Paris 06), CNRS, IRD, MNHN, LOCEAN/IPSL Laboratory, 4 Place Jussieu, 75252 Paris, France

${ }^{32}$ National Research Institute for Fisheries Science, Fisheries Research Agency 2-12-4 Fukuura, Kanazawa-Ku, Yokohama 236-8648, Japan

${ }^{33}$ Department of Meteorology and Air Quality, Environmental Sciences Group, Wageningen University, P.O. Box 47, 6700AA Wageningen, the Netherlands

${ }^{34}$ Department of Ecology, Montana State University, Bozeman, MT 59717, USA

${ }^{35}$ ANU Climate Change Institute, Fenner School of Environment and Society, Building 141, Australian National University, Canberra, ACT 0200, Australia

${ }^{36}$ Department of Earth \& Environmental Sciences, CP160/02, Université Libre de Bruxelles, 1050 Brussels, Belgium

${ }^{37}$ Max Planck Institut für Biogeochemie, P.O. Box 600164, Hans-Knöll-Str. 10, 07745 Jena, Germany

${ }^{38}$ Marine Division, Global Environment and Marine Department, Japan Meteorological Agency, 1-3-4 Otemachi, Chiyoda-ku, Tokyo 100-8122, Japan

${ }^{39}$ Ocean Processes Analysis Laboratory, University of New Hampshire, Durham, NH 03824, USA

${ }^{40}$ Centre National de Recherche Météorologique-Groupe d'Etude de l'Atmosphère Météorologique (CNRM-GAME), Météo-France/CNRS, 42 Avenue Gaspard Coriolis, 31100 Toulouse, France

${ }^{41}$ Max Planck Institute for Meteorology, Bundesstr. 53, 20146 Hamburg, Germany

${ }^{42}$ GEOMAR Helmholtz Centre for Ocean Research Kiel, Düsternbrooker Weg 20, 24105 Kiel, Germany

${ }^{43}$ Climate and Environmental Physics, and Oeschger Centre for Climate Change Research, University of Bern, Bern, Switzerland

${ }^{44}$ Imperial College London, Life Science Department, Silwood Park, Ascot, Berkshire SL5 7PY, UK

${ }^{45}$ Joint Institute for the Study of the Atmosphere and Ocean, University of Washington, Seattle, WA, USA

${ }^{46}$ Lamont-Doherty Earth Observatory of Columbia University, Palisades, NY 10964, USA

${ }^{47}$ CSIRO Oceans and Atmosphere and Antarctic Climate and Ecosystems Co-operative Research Centre, Hobart, Australia

${ }^{48}$ Faculty of Earth and Life Sciences, VU University Amsterdam, Amsterdam, the Netherlands

${ }^{49}$ CSIRO Ocean and Atmosphere, PMB \#1, Aspendale, Victoria 3195, Australia

${ }^{50}$ National Oceanic \& Atmospheric Administration/Atlantic Oceanographic \& Meteorological Laboratory (NOAA/AOML), Miami, FL 33149, USA

${ }^{51}$ Met Office Hadley Centre, FitzRoy Road, Exeter EX1 3PB, UK

${ }^{52}$ Department of Atmospheric and Oceanic Science, University of Maryland, College Park, MD 20742, USA $\dagger$ deceased

Correspondence to: C. Le Quéré (c.lequere@uea.ac.uk)

Received: 5 September 2014 - Published in Earth Syst. Sci. Data Discuss.: 21 September 2014

Revised: 18 March 2015 - Accepted: 20 March 2015 - Published: 8 May 2015

Abstract. Accurate assessment of anthropogenic carbon dioxide $\left(\mathrm{CO}_{2}\right)$ emissions and their redistribution among the atmosphere, ocean, and terrestrial biosphere is important to better understand the global carbon cycle, support the development of climate policies, and project future climate change. Here we describe data sets and a methodology to quantify all major components of the global carbon budget, including their uncertainties, based on the combination of a range of data, algorithms, statistics, and model estimates and their interpretation by a broad scientific community. We discuss changes compared to previous estimates, consistency within and among components, alongside methodology and data limitations. $\mathrm{CO}_{2}$ emissions from fossil 
fuel combustion and cement production $\left(E_{\mathrm{FF}}\right)$ are based on energy statistics and cement production data, respectively, while emissions from land-use change $\left(E_{\mathrm{LUC}}\right)$, mainly deforestation, are based on combined evidence from land-cover-change data, fire activity associated with deforestation, and models. The global atmospheric $\mathrm{CO}_{2}$ concentration is measured directly and its rate of growth $\left(G_{\mathrm{ATM}}\right)$ is computed from the annual changes in concentration. The mean ocean $\mathrm{CO}_{2}$ sink $\left(S_{\text {OCEAN }}\right)$ is based on observations from the 1990s, while the annual anomalies and trends are estimated with ocean models. The variability in $S_{\text {OCEAN }}$ is evaluated with data products based on surveys of ocean $\mathrm{CO}_{2}$ measurements. The global residual terrestrial $\mathrm{CO}_{2}$ sink $\left(S_{\text {LAND }}\right)$ is estimated by the difference of the other terms of the global carbon budget and compared to results of independent dynamic global vegetation models forced by observed climate, $\mathrm{CO}_{2}$, and land-coverchange (some including nitrogen-carbon interactions). We compare the mean land and ocean fluxes and their variability to estimates from three atmospheric inverse methods for three broad latitude bands. All uncertainties are reported as $\pm 1 \sigma$, reflecting the current capacity to characterise the annual estimates of each component of the global carbon budget. For the last decade available (2004-2013), $E_{\mathrm{FF}}$ was $8.9 \pm 0.4 \mathrm{GtC} \mathrm{yr}^{-1}, E_{\mathrm{LUC}}$ $0.9 \pm 0.5 \mathrm{GtC} \mathrm{yr}^{-1}, G_{\text {ATM }} 4.3 \pm 0.1 \mathrm{GtC} \mathrm{yr}^{-1}, S_{\text {OCEAN }} 2.6 \pm 0.5 \mathrm{GtC} \mathrm{yr}^{-1}$, and $S_{\mathrm{LAND}} 2.9 \pm 0.8 \mathrm{GtC} \mathrm{yr}^{-1}$. For year 2013 alone, $E_{\mathrm{FF}}$ grew to $9.9 \pm 0.5 \mathrm{GtC} \mathrm{yr}^{-1}, 2.3 \%$ above 2012 , continuing the growth trend in these emissions, $E_{\mathrm{LUC}}$ was $0.9 \pm 0.5 \mathrm{GtC} \mathrm{yr}^{-1}, G_{\mathrm{ATM}}$ was $5.4 \pm 0.2 \mathrm{GtC} \mathrm{yr}^{-1}, S_{\mathrm{OCEAN}}$ was $2.9 \pm 0.5 \mathrm{GtC} \mathrm{yr}^{-1}$, and $S_{\mathrm{LAND}}$ was $2.5 \pm 0.9 \mathrm{GtC} \mathrm{yr}^{-1} . G_{\mathrm{ATM}}$ was high in 2013 , reflecting a steady increase in $E_{\mathrm{FF}}$ and smaller and opposite changes between $S_{\text {OCEAN }}$ and $S_{\text {LAND }}$ compared to the past decade (2004-2013). The global atmospheric $\mathrm{CO}_{2}$ concentration reached $395.31 \pm 0.10 \mathrm{ppm}$ averaged over 2013 . We estimate that $E_{\mathrm{FF}}$ will increase by $2.5 \%(1.3-$ $3.5 \%)$ to $10.1 \pm 0.6 \mathrm{GtC}$ in $2014\left(37.0 \pm 2.2 \mathrm{GtCO}_{2} \mathrm{yr}^{-1}\right), 65 \%$ above emissions in 1990 , based on projections of world gross domestic product and recent changes in the carbon intensity of the global economy. From this projection of $E_{\mathrm{FF}}$ and assumed constant $E_{\mathrm{LUC}}$ for 2014, cumulative emissions of $\mathrm{CO}_{2}$ will reach about $545 \pm 55 \mathrm{GtC}$ $\left(2000 \pm 200 \mathrm{GtCO}_{2}\right)$ for $1870-2014$, about $75 \%$ from $E_{\mathrm{FF}}$ and $25 \%$ from $E_{\mathrm{LUC}}$. This paper documents changes in the methods and data sets used in this new carbon budget compared with previous publications of this living data set (Le Quéré et al., 2013, 2014). All observations presented here can be downloaded from the Carbon Dioxide Information Analysis Center (doi:10.3334/CDIAC/GCP_2014).

\section{Introduction}

The concentration of carbon dioxide $\left(\mathrm{CO}_{2}\right)$ in the atmosphere has increased from approximately 277 parts per million (ppm) in 1750 (Joos and Spahni, 2008), the beginning of the Industrial Era, to $395.31 \mathrm{ppm}$ in 2013 (Dlugokencky and Tans, 2014). Daily averages went above $400 \mathrm{ppm}$ for the first time at Mauna Loa station in May 2013 (Scripps, 2013). This station holds the longest running record of direct measurements of atmospheric $\mathrm{CO}_{2}$ concentration (Tans and Keeling, 2014; Fig. 1). The atmospheric $\mathrm{CO}_{2}$ increase above preindustrial levels was initially, primarily, caused by the release of carbon to the atmosphere from deforestation and other land-use-change activities (Ciais et al., 2013). While emissions from fossil fuel combustion started before the Industrial Era, they only became the dominant source of anthropogenic emissions to the atmosphere from around 1920 and their relative share has continued to increase until present. Anthropogenic emissions occur on top of an active natural carbon cycle that circulates carbon between the atmosphere, ocean, and terrestrial biosphere reservoirs on timescales from days to millennia, while exchanges with geologic reservoirs occur at longer timescales (Archer et al., 2009).

The global carbon budget presented here refers to the mean, variations, and trends in the perturbation of $\mathrm{CO}_{2}$ in the atmosphere, referenced to the beginning of the Industrial Era. It quantifies the input of $\mathrm{CO}_{2}$ to the atmosphere by emissions from human activities, the growth of $\mathrm{CO}_{2}$ in the atmosphere, and the resulting changes in the storage of carbon in the land and ocean reservoirs in response to increasing atmospheric $\mathrm{CO}_{2}$ levels, climate and climate variability, and other anthropogenic and natural changes (Fig. 2). An understanding of this perturbation budget over time and the underlying variability and trends of the natural carbon cycle are necessary to understand the response of natural sinks to changes in climate, $\mathrm{CO}_{2}$ and land-use-change drivers, and the permissible emissions for a given climate stabilisation target.

The components of the $\mathrm{CO}_{2}$ budget that are reported annually in this paper include separate estimates for (1) the $\mathrm{CO}_{2}$ emissions from fossil fuel combustion and cement production $\left(E_{\mathrm{FF}} ; \mathrm{GtC} \mathrm{yr}^{-1}\right)$, (2) the $\mathrm{CO}_{2}$ emissions resulting from deliberate human activities on land leading to land-use change (LUC; $E_{\mathrm{LUC}} ; \mathrm{GtC} \mathrm{yr}^{-1}$ ), (3) the growth rate of $\mathrm{CO}_{2}$ in the atmosphere $\left(G_{\mathrm{ATM}} ; \mathrm{GtC} \mathrm{yr}^{-1}\right)$, and the uptake of $\mathrm{CO}_{2}$ by the " $\mathrm{CO}_{2}$ sinks" in (4) the ocean $\left(S_{\mathrm{OCEAN}} ; \mathrm{GtC} \mathrm{yr}^{-1}\right)$ and (5) on land $\left(S_{\mathrm{LAND}} ; \mathrm{GtC} \mathrm{yr}^{-1}\right)$. The $\mathrm{CO}_{2}$ sinks as defined here include the response of the land and ocean to elevated $\mathrm{CO}_{2}$ and changes in climate and other environmental conditions. The global emissions and their partitioning among the atmosphere, ocean, and land are in balance: 


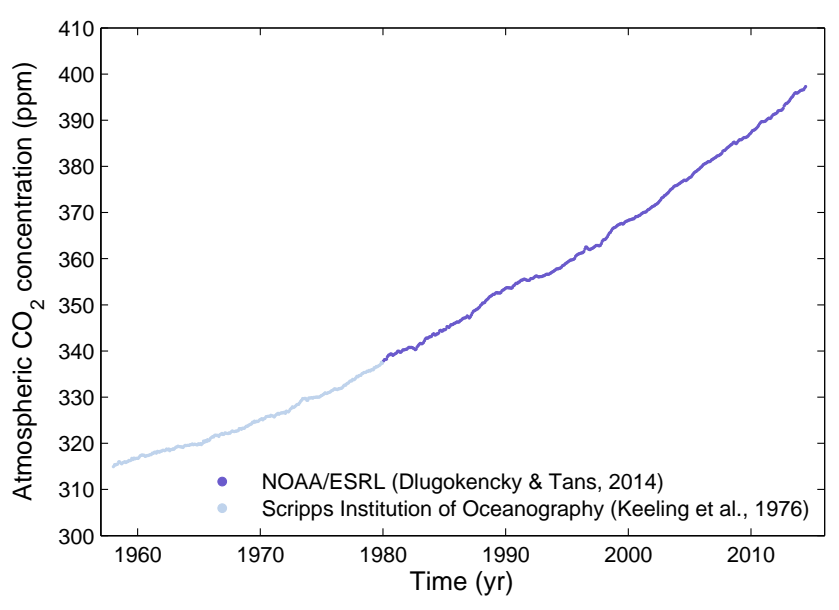

Figure 1. Surface average atmospheric $\mathrm{CO}_{2}$ concentration, deseasonalised (ppm). The 1980-2014 monthly data are from NOAA/ESRL (Dlugokencky and Tans, 2014). The 1980-2014 estimate is an average of direct atmospheric $\mathrm{CO}_{2}$ measurements from multiple stations in the marine boundary layer (Masarie and Tans, 1995). The 1958-1979 monthly data are from the Scripps Institution of Oceanography, based on an average of direct atmospheric $\mathrm{CO}_{2}$ measurements from the Mauna Loa and South Pole stations (Keeling et al., 1976). To take into account the difference of mean $\mathrm{CO}_{2}$ between the NOAA/ESRL and the Scripps station networks used here, the Scripps surface average (from two stations) was harmonised to match the NOAA/ESRL surface average (from multiple stations) by adding the mean difference of $0.542 \mathrm{ppm}$, calculated here from overlapping data during 1980-2012. The mean seasonal cycle was removed from both data sets.

$$
E_{\mathrm{FF}}+E_{\mathrm{LUC}}=G_{\mathrm{ATM}}+S_{\mathrm{OCEAN}}+S_{\mathrm{LAND}}
$$

$G_{\text {ATM }}$ is usually reported in $\mathrm{ppm} \mathrm{yr}^{-1}$, which we convert to units of carbon mass, $\mathrm{GtC} \mathrm{yr}^{-1}$, using $1 \mathrm{ppm}=2.120 \mathrm{GtC}$ (Prather et al., 2012; Table 1). We also include a quantification of $E_{\mathrm{FF}}$ by country, computed with both territorial and consumption based accounting (see Methods).

Equation (1) partly omits two kinds of processes. The first is the net input of $\mathrm{CO}_{2}$ to the atmosphere from the chemical oxidation of reactive carbon-containing gases from sources other than fossil fuels (e.g. fugitive anthropogenic $\mathrm{CH}_{4}$ emissions, industrial processes, and changes of biogenic emissions from changes in vegetation, fires, wetlands), primarily methane $\left(\mathrm{CH}_{4}\right)$, carbon monoxide $(\mathrm{CO})$, and volatile organic compounds such as isoprene and terpene. $\mathrm{CO}$ emissions are currently implicit in $E_{\mathrm{FF}}$, while anthropogenic $\mathrm{CH}_{4}$ emissions are not and thus their inclusion would result in a small increase in $E_{\mathrm{FF}}$. The second is the anthropogenic perturbation to carbon cycling in terrestrial freshwaters, estuaries, and coastal areas, which modifies lateral fluxes from land ecosystems to the open ocean, the evasion $\mathrm{CO}_{2}$ flux from rivers, lakes and estuaries to the atmosphere, and the net airsea anthropogenic $\mathrm{CO}_{2}$ flux of coastal areas (Regnier et al.,

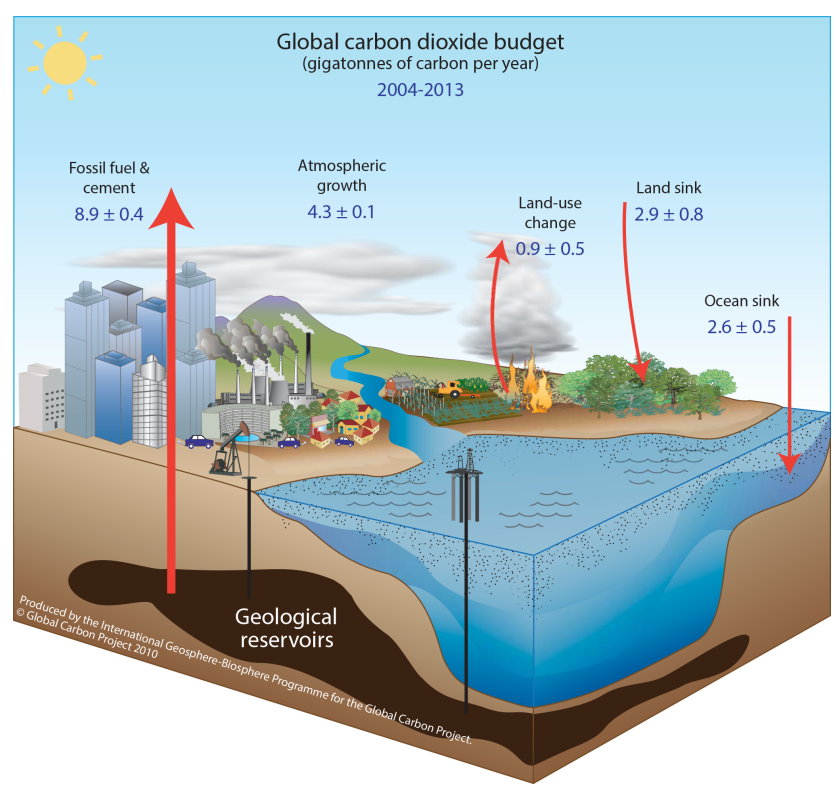

Figure 2. Schematic representation of the overall perturbation of the global carbon cycle caused by anthropogenic activities, averaged globally for the decade 2004-2013. The arrows represent emission from fossil fuel burning and cement production $\left(E_{\mathrm{FF}}\right)$, emissions from deforestation and other land-use change $\left(E_{\mathrm{LUC}}\right)$, the growth of carbon in the atmosphere $\left(G_{\mathrm{ATM}}\right)$, and the uptake of carbon by the "sinks" in the ocean $\left(S_{\text {OCEAN }}\right)$ and land $\left(S_{\text {LAND }}\right)$

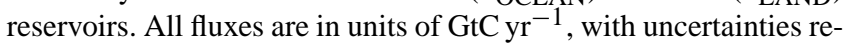
ported as $\pm 1 \sigma(68 \%$ confidence that the real value lies within the given interval) as described in the text. This figure is an update of one prepared by the International Geosphere-Biosphere Programme for the GCP, first presented in Le Quéré (2009).

2013). The inclusion of freshwater fluxes of anthropogenic $\mathrm{CO}_{2}$ would affect the estimates of, and partitioning between, $S_{\text {LAND }}$ and $S_{\text {OCEAN }}$ in Eq. (1) in complementary ways, but it would not affect the other terms. These flows are omitted in absence of annual information on the natural versus anthropogenic perturbation terms of these loops of the carbon cycle, and they are discussed in Sect. 2.7.

The $\mathrm{CO}_{2}$ budget has been assessed by the Intergovernmental Panel on Climate Change (IPCC) in all assessment reports (Ciais et al., 2013; Denman et al., 2007; Prentice et al., 2001; Schimel et al., 1995; Watson et al., 1990), as well as by others (e.g. Ballantyne et al., 2012). These assessments included budget estimates for the decades of the 1980s and 1990s (Denman et al., 2007) and, most recently, the period 2002-2011 (Ciais et al., 2013). The IPCC methodology has been adapted and used by the Global Carbon Project (GCP, www.globalcarbonproject.org), which has coordinated a cooperative community effort for the annual publication of global carbon budgets up to year 2005 (Raupach et al., 2007; including fossil emissions only), 2006 (Canadell et al., 2007), 2007 (released online; GCP, 2007), 2008 (Le Quéré et al., 2009), 2009 (Friedlingstein et al., 2010), year 2010 
Table 1. Factors used to convert carbon in various units (by convention, Unit $1=$ Unit $2 \cdot$ conversion).

\begin{tabular}{llrl}
\hline Unit 1 & Unit 2 & Conversion & Source \\
\hline GtC (gigatonnes of carbon) & ppm (parts per million) & 2.120 & Prather et al. (2012) \\
GtC (gigatonnes of carbon) & PgC (petagrams of carbon) & 1 & SI unit conversion \\
$\mathrm{GtCO}_{2}$ (gigatonnes of carbon dioxide) & GtC (gigatonnes of carbon) & 3.664 & $44.01 / 12.011$ in mass equivalent \\
GtC (gigatonnes of carbon) & MtC (megatonnes of carbon) & 1000 & SI unit conversion \\
\hline
\end{tabular}

Table 2. How to cite the individual components of the global carbon budget presented here.

\begin{tabular}{ll}
\hline Component & Primary reference \\
\hline $\begin{array}{l}\text { Territorial fossil fuel and cement emissions }\left(E_{\mathrm{FF}}\right), \\
\text { global, by fuel type, and by country }\end{array}$ & $\begin{array}{l}\text { Boden et al. (2013; CDIAC: } \\
\text { http://cdiac.ornl.gov/trends/emis/meth_reg.html) }\end{array}$ \\
\hline $\begin{array}{l}\text { Consumption-based fossil fuel and cement emissions } \\
\left(E_{\mathrm{FF}}\right) \text { by country (consumption) }\end{array}$ & Peters et al. (2011b) updated as described in this paper \\
\hline Land-use-change emissions $\left(E_{\mathrm{LUC}}\right)$ & $\begin{array}{l}\text { Houghton et al. (2012) combined with Giglio et al. } \\
(2013)\end{array}$ \\
\hline Atmospheric $\mathrm{CO}_{2}$ growth rate $\left(G_{\mathrm{ATM}}\right)$ & $\begin{array}{l}\text { Dlugokencky and Tans (2014; NOAA/ESRL: } \\
\text { www.esrl.noaa.gov/gmd/ccgg/trends/) }\end{array}$ \\
\hline Ocean and land $\mathrm{CO}_{2}$ sinks $\left(S_{\mathrm{OCEAN}}\right.$ and $\left.S_{\mathrm{LAND}}\right)$ & $\begin{array}{l}\text { This paper for } S_{\mathrm{OCEAN}} \text { and } S_{\mathrm{LAND}} \text { and references in } \\
\text { Table } 6 \text { for individual models. }\end{array}$ \\
\hline
\end{tabular}

(Peters et al., 2012b), 2012 (Le Quéré et al., 2013; Peters et al., 2013), and, most recently, 2013 (Le Quéré et al., 2014), where the carbon budget year refers to the initial year of publication. Each of these papers updated previous estimates with the latest available information for the entire time series. From 2008, these publications projected fossil fuel emissions for one additional year using the projected world gross domestic product (GDP) and estimated improvements in the carbon intensity of the global economy.

We adopt a range of \pm 1 standard deviation $(\sigma)$ to report the uncertainties in our estimates, representing a likelihood of $68 \%$ that the true value will be within the provided range if the errors have a Gaussian distribution. This choice reflects the difficulty of characterising the uncertainty in the $\mathrm{CO}_{2}$ fluxes between the atmosphere and the ocean and land reservoirs individually, particularly on an annual basis, as well as the difficulty of updating the $\mathrm{CO}_{2}$ emissions from LUC. A likelihood of $68 \%$ provides an indication of our current capability to quantify each term and its uncertainty given the available information. For comparison, the Fifth Assessment Report of the IPCC (AR5) generally reported a likelihood of $90 \%$ for large data sets whose uncertainty is well characterised, or for long time intervals less affected by year-to-year variability. Our $68 \%$ uncertainty value is near the $66 \%$ which the IPCC characterises as "likely" for values falling into the $\pm 1 \sigma$ interval. The uncertainties reported here combine statistical analysis of the underlying data and expert judgement of the likelihood of results lying outside this range. The limitations of current information are discussed in the paper.

All quantities are presented in units of gigatonnes of carbon $\left(\mathrm{GtC}, 10^{15} \mathrm{gC}\right)$, which is the same as petagrams of carbon $\left(\mathrm{PgC}\right.$; Table 1). Units of gigatonnes of $\mathrm{CO}_{2}$ (or billion tonnes of $\mathrm{CO}_{2}$ ) used in policy are equal to 3.664 multiplied by the value in units of $\mathrm{GtC}$.

This paper provides a detailed description of the data sets and methodology used to compute the global carbon budget estimates for the period pre-industrial (1750) to 2013 and in more detail for the period 1959 to 2013 . We also provide decadal averages starting in 1960 and including the last decade (2004-2013), results for the year 2013, and a projection of $E_{\mathrm{FF}}$ for year 2014. Finally, we provide the total or cumulative emissions from fossil fuels and land-use change since the year 1750; the pre-industrial period; and since year 1870, the reference year for the cumulative carbon estimate used by the IPCC (AR5) based on the availability of global temperature data (Stocker et al., 2013b). This paper will be updated every year using the format of "living data" so as to keep a record of budget versions and the changes in new data, revision of data, and changes in methodology that lead to changes in estimates of the carbon budget. Additional materials associated with the release of each new version will be posted on the Global Carbon Project (GCP) website (http://www.globalcarbonproject.org/carbonbudget). Data associated with this release are also available through the Global Carbon Atlas (http://www.globalcarbonatlas.org). With this approach, we aim to provide the highest trans- 
parency and traceability in the reporting of key indicators and drivers of climate change.

\section{Methods}

Multiple organisations and research groups around the world generated the original measurements and data used to complete the global carbon budget. The effort presented here is thus mainly one of synthesis, where results from individual groups are collated, analysed, and evaluated for consistency. We facilitate access to original data with the understanding that primary data sets will be referenced in future work (see Table 2 for how to cite the data sets). Descriptions of the measurements, models, and methodologies follow below, and in-depth descriptions of each component are described elsewhere (e.g. Andres et al., 2012; Houghton et al., 2012).

This is the ninth version of the "global carbon budget" (see Introduction for details) and the third revised version of the "global carbon budget living data paper". It is an update of Le Quéré et al. (2014), including data to year 2013 (inclusive) and a projection for fossil fuel emissions for year 2014. The main changes from Le Quéré et al. (2014) are as follows: (1) we use 3 years of BP energy consumption growth rates (coal, oil, gas) to estimate $E_{\mathrm{FF}}$ compared to 2 years in the previous version (Sect. 2.1), (2) we updated $S_{\text {OCEAN }}$ estimates from observations to 2013 extending the Surface Ocean $\mathrm{CO}_{2}$ Atlas (SOCAT) v2 database (Bakker et al., 2014; Sect. 2.4) with additional new cruises, and (3) we introduced results from three atmospheric inverse methods using atmospheric measurements from a global network of surface stations through 2013 that provide a latitudinal breakdown of the combined land and ocean fluxes (Sect. 2.6). The main methodological differences between annual carbon budgets are summarised in Table 3.

\section{1 $\mathrm{CO}_{2}$ emissions from fossil fuel combustion and cement production $\left(E_{\mathrm{FF}}\right)$}

\subsubsection{Fossil fuel and cement emissions and their uncertainty}

The calculation of global and national $\mathrm{CO}_{2}$ emissions from fossil fuel combustion, including gas flaring and cement production $\left(E_{\mathrm{FF}}\right)$, relies primarily on energy consumption data, specifically data on hydrocarbon fuels, collated and archived by several organisations (Andres et al., 2012). These include the Carbon Dioxide Information Analysis Center (CDIAC), the International Energy Agency (IEA), the United Nations (UN), the United States Department of Energy (DoE) Energy Information Administration (EIA), and more recently also the Planbureau voor de Leefomgeving (PBL) of the Netherlands Environmental Assessment Agency. We use the emissions estimated by the CDIAC (Boden et al., 2013). The CDIAC emission estimates constitute the only data set that extends back in time to 1751 with consistent and well- documented emissions from fossil fuel combustion, cement production, and gas flaring for all countries and their uncertainty (Andres et al., 1999, 2012, 2014); this makes the data set a unique resource for research of the carbon cycle during the fossil fuel era.

During the period 1959-2010, the emissions from fossil fuel consumption are based primarily on energy data provided by the UN Statistics Division (Table 4; UN, 2013a, b). When necessary, fuel masses/volumes are converted to fuel energy content using coefficients provided by the UN and then to $\mathrm{CO}_{2}$ emissions using conversion factors that take into account the relationship between carbon content and energy (heat) content of the different fuel types (coal, oil, gas, gas flaring) and the combustion efficiency (to account, for example, for soot left in the combustor or fuel otherwise lost or discharged without oxidation). Most data on energy consumption and fuel quality (carbon content and heat content) are available at the country level (UN, 2013a). In general, $\mathrm{CO}_{2}$ emissions for equivalent primary energy consumption are about $30 \%$ higher for coal compared to oil, and $70 \%$ higher for coal compared to natural gas (Marland et al., 2007). All estimated fossil fuel emissions are based on the mass flows of carbon and assume that the fossil carbon emitted as $\mathrm{CO}$ or $\mathrm{CH}_{4}$ will soon be oxidised to $\mathrm{CO}_{2}$ in the atmosphere and can be accounted for with $\mathrm{CO}_{2}$ emissions (see Sect. 2.7).

For the three most recent years (2011, 2012, and 2013) when the UN statistics are not yet available, we generated preliminary estimates based on the BP annual energy review by applying the growth rates of energy consumption (coal, oil, gas) for 2011-2013 (BP, 2014) to the CDIAC emissions in 2010. BP's sources for energy statistics overlap with those of the UN data but are compiled more rapidly from about 70 countries covering about $96 \%$ of global emissions. We use the BP values only for the year-to-year rate of change, because the rates of change are less uncertain than the absolute values and to avoid discontinuities in the time series when linking the UN-based energy data (up to 2010) with the BP energy data (2011-2013). These preliminary estimates are replaced with the more complete CDIAC data based on UN statistics when they become available. Past experience and work by others (Andres et al., 2014) shows that projections based on the BP rate of change are within the uncertainty provided (see Sect. 3.2 and Supplement from Peters et al., 2013).

Emissions from cement production are based on cement production data from the U.S. Geological Survey up to year 2012 (van Oss, 2013), and up to 2013 for the top 18 countries (representing $85 \%$ of global production; USGS, 2014). For countries without data in 2013 we use the 2012 values (zero growth). Some fraction of the $\mathrm{CaO}$ and $\mathrm{MgO}$ in cement is returned to the carbonate form during cement weathering, but this is generally regarded to be small and is ignored here.

Emission estimates from gas flaring are calculated in a similar manner as those from solid, liquid, and gaseous fuels, and rely on the UN Energy Statistics to supply the amount 
Table 3. Main methodological changes in the global carbon budget since first publication. Unless specified below, the methodology was identical to that described in the current paper. Furthermore, methodological changes introduced in one year are kept for the following years unless noted. Empty cells mean there were no methodological changes introduced that year.

\begin{tabular}{|c|c|c|c|c|c|c|c|c|}
\hline \multirow{2}{*}{$\begin{array}{l}\text { Publication } \\
\text { year }^{\mathrm{a}}\end{array}$} & \multicolumn{3}{|c|}{ Fossil fuel emissions } & \multirow{2}{*}{$\begin{array}{l}\text { LUC } \\
\text { emissions }\end{array}$} & \multicolumn{3}{|c|}{ Reservoirs } & \multirow{2}{*}{$\begin{array}{l}\text { Uncertainty \& } \\
\text { other changes }\end{array}$} \\
\hline & Global & Country (territorial) & $\begin{array}{l}\text { Country } \\
\text { (consumption) }\end{array}$ & & Atmosphere & Ocean & Land & \\
\hline $\begin{array}{l}2006 \\
\text { Raupach et } \\
\text { al. (2007) }\end{array}$ & & Split in regions & & & & & & \\
\hline $\begin{array}{l}2007 \\
\text { Canadell et } \\
\text { al. (2007) }\end{array}$ & & & & $\begin{array}{l}E_{\mathrm{LUC}} \text { based on FAO- } \\
\text { FRA } 2005 ; \text { constant } \\
E_{\mathrm{LUC}} \text { for } 2006\end{array}$ & $\begin{array}{l}\text { 1959-1979 data from } \\
\text { Mauna Loa; data after } \\
1980 \text { from global aver- } \\
\text { age }\end{array}$ & $\begin{array}{l}\text { Based on one ocean } \\
\text { model tuned to repro- } \\
\text { duced observed } 1990 \text { s } \\
\text { sink }\end{array}$ & & $\begin{array}{l} \pm 1 \sigma \text { provided for all } \\
\text { components }\end{array}$ \\
\hline $\begin{array}{l}2008 \\
\text { (online) }\end{array}$ & & & & $\begin{array}{lll}\text { Constant } & E_{\text {LUC }} & \text { for } \\
2007 & & \end{array}$ & & & & \\
\hline $\begin{array}{l}2009 \\
\text { Le Quéré et } \\
\text { al. (2009) }\end{array}$ & & $\begin{array}{l}\text { Split between Annex } \\
\text { B and non-Annex B }\end{array}$ & $\begin{array}{l}\text { Results from an indepen- } \\
\text { dent study discussed }\end{array}$ & \begin{tabular}{lll} 
Fire-based & \multicolumn{2}{c}{ emission } \\
anomalies & used for \\
$2006-2008$ & &
\end{tabular} & & $\begin{array}{l}\text { Based on four ocean } \\
\text { models normalised to } \\
\text { observations with con- } \\
\text { stant delta }\end{array}$ & $\begin{array}{l}\text { First use of five } \\
\text { DGVMs to compare } \\
\text { with budget residual }\end{array}$ & \\
\hline $\begin{array}{l}2010 \\
\text { Friedlingstein } \\
\text { et al. (2010) }\end{array}$ & $\begin{array}{l}\text { Projection for current } \\
\text { year based on GDP }\end{array}$ & $\begin{array}{l}\text { Emissions for top } \\
\text { emitters }\end{array}$ & & $\begin{array}{l}E_{\text {LUC }} \text { updated with } \\
\text { FAO-FRA } 2010\end{array}$ & & & & \\
\hline $\begin{array}{l}2011 \\
\text { Peters et al. } \\
(2012 b)\end{array}$ & & & $\begin{array}{l}\text { Split between Annex B } \\
\text { and non-Annex B }\end{array}$ & & & & & \\
\hline $\begin{array}{l}2012 \\
\text { Le Quéré et } \\
\text { al. (2013) } \\
\text { Peters et } \\
\text { al. (2013) }\end{array}$ & & $\begin{array}{l}129 \text { countries from } \\
1959\end{array}$ & $\begin{array}{l}129 \text { countries and regions } \\
\text { from } 1990 \text { to } 2010 \text { based } \\
\text { on GTAP8.0 }\end{array}$ & $\begin{array}{l}E_{\text {LUC for }} 1997-2011 \\
\text { includes interannual } \\
\text { anomalies from fire- } \\
\text { based emissions }\end{array}$ & $\begin{array}{l}\text { All years from global } \\
\text { average }\end{array}$ & $\begin{array}{l}\text { Based on five ocean } \\
\text { models normalised to } \\
\text { observations with ratio }\end{array}$ & $\begin{array}{l}\text { Nine DGVMs available } \\
\text { for } S_{\text {LAND }} \text {; first use of } \\
\text { four models to compare } \\
\text { with } E_{\text {LUC }}\end{array}$ & \\
\hline $\begin{array}{l}2013 \\
\text { Le Quéré et } \\
\text { al. (2014) }\end{array}$ & & 250 countries $^{b}$ & $\begin{array}{l}134 \text { countries and re- } \\
\text { gions } 1990-2011 \text { based } \\
\text { on GTAP8.1 }\end{array}$ & $\begin{array}{l}E_{\text {LUC }} \text { for } 2012 \text { esti- } \\
\text { mated from 2001-2010 } \\
\text { average }\end{array}$ & & $\begin{array}{l}\text { Based on six models } \\
\text { compared with two } \\
\text { data-products to year } \\
2011\end{array}$ & $\begin{array}{l}\text { Coordinated DGVM } \\
\text { experiments for } S_{\mathrm{LAND}} \\
\text { and } E_{\mathrm{LUC}}\end{array}$ & $\begin{array}{l}\text { Confidence levels; } \\
\text { cumulative emissions; } \\
\text { budget from } 1750\end{array}$ \\
\hline $\begin{array}{l}2014 \\
\text { (this study) }\end{array}$ & $\begin{array}{l}\text { Three years of } \mathrm{BP} \\
\text { data }\end{array}$ & $\begin{array}{l}\text { Three years of BP } \\
\text { data }\end{array}$ & $\begin{array}{l}\text { Extended to } 2012 \text { with } \\
\text { updated GDP data }\end{array}$ & $\begin{array}{l}E_{\text {LUC for }} 1997-2013 \\
\text { includes interannual } \\
\text { anomalies from fire- } \\
\text { based emissions }\end{array}$ & & $\begin{array}{l}\text { Based on seven mod- } \\
\text { els compared with three } \\
\text { data products to year } \\
2013\end{array}$ & Based on 10 models & $\begin{array}{l}\text { Inclusion of breakdown } \\
\text { of the sinks in three lat- } \\
\text { itude band and compar- } \\
\text { ison with three atmo- } \\
\text { spheric inversions }\end{array}$ \\
\hline
\end{tabular}

of flared or vented fuel. For emission years 2011-2013, flaring is assumed constant from 2010 (emission year) UN-based data. The basic data on gas flaring report atmospheric losses during petroleum production and processing that have large uncertainty and do not distinguish between gas that is flared as $\mathrm{CO}_{2}$ or vented as $\mathrm{CH}_{4}$. Fugitive emissions of $\mathrm{CH}_{4}$ from the so-called upstream sector (e.g. coal mining and natural gas distribution) are not included in the accounts of $\mathrm{CO}_{2}$ emissions except to the extent that they are captured in the UN energy data and counted as gas "flared or lost".

The published CDIAC data set has 250 countries and regions included. This expanded list includes countries/regions that no longer exist, such as the USSR and East Pakistan. For the budget, we reduce the list to 216 countries by reallocating emissions to the currently defined territories. This involved both aggregation and disaggregation, and does not change global emissions. Examples of aggregation include merging East and West Germany to the currently defined Germany. Examples of disaggregation include reallocating the emissions from the former USSR to the resulting independent countries. For disaggregation, we use the emission shares when the current territory first appeared. For the most recent years, 2011-2013, the BP statistics are more aggregated, but we retain the detail of CDIAC by applying the growth rates of each aggregated region in the BP data set to its constituent individual countries in CDIAC.

Estimates of $\mathrm{CO}_{2}$ emissions show that the global total of emissions is not equal to the sum of emissions from all countries. This is largely attributable to emissions that occur in international territory, in particular the combustion of fuels used in international shipping and aviation (bunker fuels), where the emissions are included in the global totals but are not attributed to individual countries. In practice, the emissions from international bunker fuels are calculated based on where the fuels were loaded, but they are not included with national emissions estimates. Other differences occur because globally the sum of imports in all countries is not equal to the sum of exports and because of differing treatment of oxidation of non-fuel uses of hydrocarbons (e.g. as solvents, lubricants, feedstocks), and changes in stock (Andres et al., 2012).

The uncertainty in the annual fossil fuel and cement emissions for the globe has been estimated at $\pm 5 \%$ (scaled down from the published $\pm 10 \%$ at $\pm 2 \sigma$ to the use of $\pm 1 \sigma$ bounds reported here; Andres et al., 2012). This is consistent with a more detailed recent analysis of uncertainty of $\pm 8.4 \%$ at $\pm 2 \sigma$ (Andres et al., 2014). This includes an assessment of uncertainties in the amounts of fuel consumed, the carbon 
Table 4. Data sources used to compute each component of the global carbon budget.

\begin{tabular}{|c|c|c|c|}
\hline Component & Process & Data source & Data reference \\
\hline$E_{\mathrm{FF}}$ & $\begin{array}{l}\text { Fossil fuel combustion and gas flaring } \\
\text { Cement production }\end{array}$ & $\begin{array}{l}\text { UN Statistics Division to } 2010 \\
\text { BP for 2011-2013 } \\
\text { U.S. Geological Survey }\end{array}$ & $\begin{array}{l}\text { UN (2013a, b) } \\
\text { BP (2014) } \\
\text { van Oss (2013) } \\
\text { U.S. Geological Survey (2012) }\end{array}$ \\
\hline$E_{\text {LUC }}$ & $\begin{array}{l}\text { Land-cover change (deforestation, afforesta- } \\
\text { tion, and forest regrowth) } \\
\text { Wood harvest } \\
\text { Shifting agriculture } \\
\text { Interannual variability from peat fires and } \\
\text { climate-land management interactions (1997- } \\
\text { 2013) }\end{array}$ & $\begin{array}{l}\text { Forest Resource Assessment (FRA) of the Food } \\
\text { and Agriculture Organization (FAO) } \\
\text { FAO Statistics Division } \\
\text { FAO FRA and Statistics Division } \\
\text { Global Fire Emissions Database (GFED4) }\end{array}$ & $\begin{array}{l}\text { FAO (2010) } \\
\text { FAOSTAT (2010) } \\
\text { FAO (2010), FAOSTAT (2010) } \\
\text { Giglio et al. (2013) }\end{array}$ \\
\hline$G_{\mathrm{ATM}}$ & Change in atmospheric $\mathrm{CO}_{2}$ concentration & $\begin{array}{l}\text { 1959-1980: } \mathrm{CO}_{2} \text { Program at Scripps Institution } \\
\text { of Oceanography and other research groups } \\
\text { 1980-2013: US National Oceanic and Atmo- } \\
\text { spheric Administration Earth System Research } \\
\text { Laboratory }\end{array}$ & $\begin{array}{l}\text { Keeling et al. (1976) } \\
\text { Dlugokencky and Tans (2014) } \\
\text { Ballantyne et al. (2012) }\end{array}$ \\
\hline$S_{\text {OCEAN }}$ & $\begin{array}{l}\text { Impact of increasing atmospheric } \mathrm{CO}_{2} \text {, climate } \\
\text { and variability }\end{array}$ & $\begin{array}{l}\text { 1990-1999 average: indirect estimates based on } \\
\text { CFCs, atmospheric } \mathrm{O}_{2} \text {, and other tracer obser- } \\
\text { vations }\end{array}$ & $\begin{array}{l}\text { Manning and Keeling (2006) } \\
\text { Keeling et al. (2011) } \\
\text { McNeil et al. (2003) } \\
\text { Mikaloff Fletcher et al. (2006) as assessed } \\
\text { by the IPCC } \\
\text { Denman et al. (2007) } \\
\text { Table } 6\end{array}$ \\
\hline$S_{\text {LAND }}$ & $\begin{array}{l}\text { Response of land vegetation to } \\
\text { increasing atmospheric } \mathrm{CO}_{2} \text { concentration, } \\
\text { climate and variability and } \\
\text { other environmental changes }\end{array}$ & Budget residual & \\
\hline
\end{tabular}

and heat contents of fuels, and the combustion efficiency. While in the budget we consider a fixed uncertainty of $\pm 5 \%$ for all years, in reality the uncertainty, as a percentage of the emissions, is growing with time because of the larger share of global emissions from non-Annex B countries (emerging economies and developing countries) with less precise statistical systems (Marland et al., 2009). For example, the uncertainty in Chinese emissions has been estimated at around $\pm 10 \%$ (for $\pm 1 \sigma$; Gregg et al., 2008). Generally, emissions from mature economies with good statistical bases have an uncertainty of only a few percent (Marland, 2008). Further research is needed before we can quantify the time evolution of the uncertainty, and its temporal error correlation structure. We note that, even if they are presented as $1 \sigma$ estimates, uncertainties of emissions are likely to be mainly country-specific systematic errors related to underlying biases of energy statistics and to the accounting method used by each country. We assign a medium confidence to the results presented here because they are based on indirect estimates of emissions using energy data (Durant et al., 2010). There is only limited and indirect evidence for emissions, although there is a high agreement among the available estimates within the given uncertainty (Andres et al., 2012, 2014), and emission estimates are consistent with a range of other observations (Ciais et al., 2013), even though their re- gional and national partitioning is more uncertain (Francey et al., 2013).

\subsubsection{Emissions embodied in goods and services}

National emission inventories take a territorial (production) perspective and "include greenhouse gas emissions and removals taking place within national territory and offshore areas over which the country has jurisdiction" (Rypdal et al., 2006). That is, emissions are allocated to the country where and when the emissions actually occur. The territorial emission inventory of an individual country does not include the emissions from the production of goods and services produced in other countries (e.g. food and clothes) that are used for consumption. Consumption-based emission inventories for an individual country is another attribution point of view that allocates global emissions to products that are consumed within a country, and are conceptually calculated as the territorial emissions minus the "embedded" territorial emissions to produce exported products plus the emissions in other countries to produce imported products (consumption $=$ territorial - exports + imports). The difference between the territorial- and consumption-based emission inventories is the net transfer (exports minus imports) of emissions from the production of internationally traded products. Consumption-based emission attribution results (e.g. 
Davis and Caldeira, 2010) provide additional information on territorial-based emissions that can be used to understand emission drivers (Hertwich and Peters, 2009), quantify emission (virtual) transfers by the trade of products between countries (Peters et al., 2011b), and potentially design more effective and efficient climate policy (Peters and Hertwich, 2008).

We estimate consumption-based emissions by enumerating the global supply chain using a global model of the economic relationships between economic sectors within and between every country (Andrew and Peters, 2013; Peters et al., 2011a). Due to availability of the input data, detailed estimates are made for the years 1997, 2001, 2004, and 2007 (using the methodology of Peters et al., 2011b) using economic and trade data from the Global Trade and Analysis Project version 8.1 (GTAP; Narayanan et al., 2013). The results cover 57 sectors and 134 countries and regions. The results are extended into an annual time series from 1990 to the latest year of the fossil fuel emissions or GDP data (2012 in this budget), using GDP data by expenditure in current exchange rate of US dollars (USD; from the UN National Accounts Main Aggregates database; UN, 2014) and time series of trade data from GTAP (based on the methodology in Peters et al., 2011b).

The consumption-based emission inventories in this carbon budget incorporate several improvements over previous versions (Le Quéré et al., 2013; Peters et al., 2011b, 2012b). The detailed estimates for 2004 and 2007 and time series approximation from 1990 to 2012 are based on an updated version of the GTAP database (Narayanan et al., 2013). We estimate the sector level $\mathrm{CO}_{2}$ emissions using our own calculations based on the GTAP data and methodology, include flaring and cement emissions from CDIAC, and then scale the national totals (excluding bunker fuels) to match the CDIAC estimates from the most recent carbon budget. We do not include international transportation in our estimates of national totals, but we do include them in the global total. The time series of trade data provided by GTAP covers the period 19952009 and our methodology uses the trade shares as this data set. For the period 1990-1994 we assume the trade shares of 1995, while for 2010 and 2011 we assume the trade shares of 2008 since 2009 was heavily affected by the global financial crisis. We identified errors in the trade shares of Taiwan in 2008 and 2009, so its trade shares for 2008-2010 are based on the 2007 trade shares.

We do not provide an uncertainty estimate for these emissions, but based on model comparisons and sensitivity analysis, they are unlikely to be larger than for the territorial emission estimates (Peters et al., 2012a). Uncertainty is expected to increase for more detailed results and decrease with aggregation (Peters et al., 2011b; e.g. the results for Annex B countries will be more accurate than the sector results for an individual country).

The consumption-based emissions attribution method considers the $\mathrm{CO}_{2}$ emitted to the atmosphere in the production of products, but not the trade in fossil fuels (coal, oil, gas). It is also possible to account for the carbon trade in fossil fuels (Davis et al., 2011), but we do not present those data here. Peters et al. (2012a) additionally considered trade in biomass.

The consumption data do not modify the global average terms in Eq. (1), but they are relevant to the anthropogenic carbon cycle as they reflect the trade-driven movement of emissions across the Earth's surface in response to human activities. Furthermore, if national and international climate policies continue to develop in an unharmonised way, then the trends reflected in these data will need to be accommodated by those developing policies.

\subsubsection{Growth rate in emissions}

We report the annual growth rate in emissions for adjacent years (in percent per year) by calculating the difference between the 2 years and then comparing to the emissions in the first year: $\left[\frac{E_{\mathrm{FF}\left(t_{0+1}\right)-E_{\mathrm{FF}\left(t_{0}\right)}}}{E_{\mathrm{FF}\left(t_{0}\right)}}\right] \times \% \mathrm{yr}^{-1}$. This is the simplest method to characterise a 1-year growth compared to the previous year and is widely used. We apply a leap-year adjustment to ensure valid interpretations of annual growth rates. This affects the growth rate by about $0.3 \% \mathrm{yr}^{-1}\left(\frac{1}{365}\right)$ and causes growth rates to go up approximately $0.3 \%$ if the first year is a leap year and down $0.3 \%$ if the second year is a leap year.

The relative growth rate of $E_{\mathrm{FF}}$ over time periods of greater than 1 year can be re-written using its logarithm equivalent as follows:

$\frac{1}{E_{\mathrm{FF}}} \frac{\mathrm{d} E_{\mathrm{FF}}}{\mathrm{d} t}=\frac{\mathrm{d}\left(\ln E_{\mathrm{FF}}\right)}{\mathrm{d} t}$.

Here we calculate relative growth rates in emissions for multi-year periods (e.g. a decade) by fitting a linear trend to $\ln \left(E_{\mathrm{FF}}\right)$ in Eq. (2), reported in percent per year. We fit the logarithm of $E_{\mathrm{FF}}$ rather than $E_{\mathrm{FF}}$ directly because this method ensures that computed growth rates satisfy Eq. (6). This method differs from previous papers (Canadell et al., 2007; Le Quéré et al., 2009; Raupach et al., 2007) that computed the fit to $E_{\mathrm{FF}}$ and divided by average $E_{\mathrm{FF}}$ directly, but the difference is very small $(<0.05 \%)$ in the case of $E_{\mathrm{FF}}$.

\subsubsection{Emissions projections using GDP projections}

Energy statistics are normally available around June for the previous year. We use the close relationship between the growth in world GDP and the growth in global emissions (Raupach et al., 2007) to project emissions for the current year. This is based on the so-called Kaya identity (also called IPAT identity, the acronym standing for human impact (I) on the environment, which is equal to the product of population $(\mathrm{P})$, affluence $(\mathrm{A})$, and technology $(\mathrm{T})$, whereby $E_{\mathrm{FF}}\left(\mathrm{GtC} \mathrm{yr}^{-1}\right)$ is decomposed by the product of 
GDP (USD yr ${ }^{-1}$ ) and the fossil fuel carbon intensity of the economy $\left(I_{\mathrm{FF}} ; \mathrm{GtC} \mathrm{USD}^{-1}\right)$ as follows:

$E_{\mathrm{FF}}=\mathrm{GDP} \times I_{\mathrm{FF}}$.

Such product-rule decomposition identities imply that the relative growth rates of the multiplied quantities are additive. Taking a time derivative of Eq. (3) gives

$\frac{\mathrm{d} E_{\mathrm{FF}}}{\mathrm{d} t}=\frac{\mathrm{d}\left(\mathrm{GDP} \times I_{\mathrm{FF}}\right)}{\mathrm{d} t}$,

and, applying the rules of calculus,

$\frac{\mathrm{d} E_{\mathrm{FF}}}{\mathrm{d} t}=\frac{\mathrm{dGDP}}{\mathrm{d} t} \times I_{\mathrm{FF}}+\mathrm{GDP} \times \frac{\mathrm{d} I_{\mathrm{FF}}}{\mathrm{d} t} ;$

finally, dividing Eq. (5) by Eq. (3) gives

$$
\frac{1}{E_{\mathrm{FF}}} \frac{\mathrm{d} E_{\mathrm{FF}}}{\mathrm{d} t}=\frac{1}{\mathrm{GDP}} \frac{\mathrm{dGDP}}{\mathrm{d} t}+\frac{1}{I_{\mathrm{FF}}} \frac{\mathrm{d} I_{\mathrm{FF}}}{\mathrm{d} t},
$$

where the left-hand term is the relative growth rate of $E_{\mathrm{FF}}$, and the right-hand terms are the relative growth rates of GDP and $I_{\mathrm{FF}}$, respectively, which can simply be added linearly to give overall growth rate. The growth rates are reported in percent by multiplying each term by 100 . As preliminary estimates of annual change in GDP are made well before the end of a calendar year, making assumptions on the growth rate of $I_{\mathrm{FF}}$ allows us to make projections of the annual change in $\mathrm{CO}_{2}$ emissions well before the end of a calendar year.

\section{$2.2 \mathrm{CO}_{2}$ emissions from land use, land-use change, and forestry ( $\left.E_{\text {LUC }}\right)$}

LUC emissions reported in the 2014 carbon budget ( $E_{\mathrm{LUC}}$ ) include $\mathrm{CO}_{2}$ fluxes from deforestation, afforestation, logging (forest degradation and harvest activity), shifting cultivation (cycle of cutting forest for agriculture and then abandoning), and regrowth of forests following wood harvest or abandonment of agriculture. Only some land management activities (Table 5) are included in our LUC emissions estimates (e.g. emissions or sinks related to management and management changes in established pasture and croplands are not included). Some of these activities lead to emissions of $\mathrm{CO}_{2}$ to the atmosphere, while others lead to $\mathrm{CO}_{2}$ sinks. $E_{\mathrm{LUC}}$ is the net sum of all anthropogenic activities considered. Our annual estimate for 1959-2010 is from a bookkeeping method (Sect. 2.2.1) primarily based on net forest area change and biomass data from the Forest Resource Assessment (FRA) of the Food and Agriculture Organization (FAO), which is only available at intervals of 5 years and ends in 2010 (Houghton et al., 2012). Interannual variability in emissions due to deforestation and degradation have been coarsely estimated from satellite-based fire activity in tropical forest areas (Sect. 2.2.2; Giglio et al., 2013; van der Werf et al., 2010). The bookkeeping method is used to quantify the $E_{\mathrm{LUC}}$ over the time period of the available data, and the satellite-based deforestation fire information to incorporate interannual variability ( $E_{\mathrm{LUC}}$ flux annual anomalies) from tropical deforestation fires. The satellite-based deforestation and degradation fire emissions estimates are available for years 1997-2013. We calculate the global annual anomaly in deforestation and degradation fire emissions in tropical forest regions for each year, compared to the 19972010 period, and add this annual flux anomaly to the $E_{\mathrm{LUC}}$ estimated using the bookkeeping method that is available up to 2010 only and assumed constant at the 2010 value during the period 2011-2013. We thus assume that all land management activities apart from deforestation and degradation do not vary significantly on a year-to-year basis. Other sources of interannual variability (e.g. the impact of climate variability on regrowth fluxes) are accounted for in $S_{\text {LAND. In ad- }}$ dition, we use results from dynamic global vegetation models (see Sect. 2.2.3 and Table 6) that calculate net $\mathrm{LUC} \mathrm{CO}_{2}$ emissions in response to land-cover-change reconstructions prescribed to each model in order to help quantify the uncertainty in $E_{\mathrm{LUC}}$ and to explore the consistency of our understanding. The three methods are described below, and differences are discussed in Sect. 3.2.

\subsubsection{Bookkeeping method}

LUC CO $\mathrm{C}_{2}$ emissions are calculated by a bookkeeping method approach (Houghton, 2003) that keeps track of the carbon stored in vegetation and soils before deforestation or other land-use change, and the changes in forest age classes, or cohorts, of disturbed lands after land-use change including possible forest regrowth after deforestation. It tracks the $\mathrm{CO}_{2}$ emitted to the atmosphere immediately during deforestation, and over time due to the follow-up decay of soil and vegetation carbon in different pools, including wood product pools after logging and deforestation. It also tracks the regrowth of vegetation and associated build-up of soil carbon pools after LUC. It considers transitions between forests, pastures, and cropland; shifting cultivation; degradation of forests where a fraction of the trees is removed; abandonment of agricultural land; and forest management such as wood harvest and, in the USA, fire management. In addition to tracking logging debris on the forest floor, the bookkeeping method tracks the fate of carbon contained in harvested wood products that is eventually emitted back to the atmosphere as $\mathrm{CO}_{2}$, although a detailed treatment of the lifetime in each product pool is not performed (Earles et al., 2012). Harvested wood products are partitioned into three pools with different turnover times. All fuel wood is assumed burned in the year of harvest $\left(1.0 \mathrm{yr}^{-1}\right)$. Pulp and paper products are oxidised at a rate of $0.1 \mathrm{yr}^{-1}$, timber is assumed to be oxidised at a rate of $0.01 \mathrm{yr}^{-1}$, and elemental carbon decays at $0.001 \mathrm{yr}^{-1}$. The general assumptions about partitioning wood products among these pools are based on national harvest data (Houghton, 2003).

The primary land-cover-change and biomass data for the bookkeeping method analysis are from the Forest Resource 
Table 5. Comparison of the processes included in the $E_{\mathrm{LUC}}$ of the global carbon budget and the DGVMs. See Table 6 for model references. All models include deforestation and forest regrowth after abandonment of agriculture (or from afforestation activities on agricultural land).

\begin{tabular}{|c|c|c|c|c|c|c|c|c|c|c|c|}
\hline & 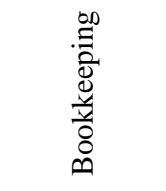 & 兊 & 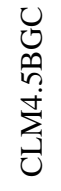 & 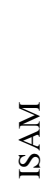 & 㠫 & 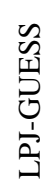 & $\vec{a}$ & $\stackrel{x}{a}$ & 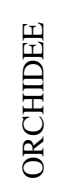 & 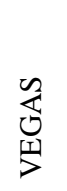 & $\stackrel{5}{5}$ \\
\hline $\begin{array}{l}\text { Wood harvest and for- } \\
\text { est degradation }{ }^{\mathrm{a}}\end{array}$ & yes & yes & yes & yes & no & no & no & no & no & yes & yes $^{b}$ \\
\hline Shifting cultivation & yes & no & yes & no & no & no & no & no & no ${ }^{\mathrm{c}}$ & no ${ }^{\mathrm{d}}$ & yes \\
\hline Cropland harvest & yes & yes & yes & no & no & yes & no & yes & yes & yes & yes \\
\hline Peat fires & no & no & yes & no & no & no & no & no & no & no & no \\
\hline $\begin{array}{l}\text { Fire simulation and/or } \\
\text { suppression }\end{array}$ & for US only & no & yes & no & no & yes & yes & yes & no & yes & yes \\
\hline Climate and variability & no & yes & yes & yes & yes & yes & yes & yes & yes & yes & yes \\
\hline $\mathrm{CO}_{2}$ fertilisation & no & yes & yes & yes & yes & yes & yes & yes & yes & yes & yes \\
\hline $\begin{array}{l}\text { Carbon-nitrogen } \\
\text { interactions, including } \\
\mathrm{N} \text { deposition }\end{array}$ & no & yes & yes & yes & no & no & no & yes & no & no & no \\
\hline
\end{tabular}

${ }^{a}$ Refers to the routine harvest of established managed forests rather than pools of harvested products. ${ }^{\mathrm{b}}$ Wood stems are harvested according to the land-use data. ${ }^{\mathrm{c}}$ Models only used to calculate $S_{\mathrm{LAND}}{ }^{\mathrm{d}}$ Model only used to compare $E_{\mathrm{LUC}}+S_{\mathrm{LAND}}$ to atmospheric inversions (Fig. 6).

Assessment of the FAO, which provides statistics on forestcover change and management at intervals of 5 years (FAO, 2010). The data are based on countries' self-reporting, some of which includes satellite data in more recent assessments (Table 4). Changes in land cover other than forest are based on annual, national changes in cropland and pasture areas reported by the FAO Statistics Division (FAOSTAT, 2010). LUC country data are aggregated by regions. The carbon stocks on land (biomass and soils), and their response functions subsequent to LUC, are based on FAO data averages per land-cover type, biome, and region. Similar results were obtained using forest biomass carbon density based on satellite data (Baccini et al., 2012). The bookkeeping method does not include land ecosystems' transient response to changes in climate, atmospheric $\mathrm{CO}_{2}$, and other environmental factors, but the growth/decay curves are based on contemporary data that will implicitly reflect the effects of $\mathrm{CO}_{2}$ and climate at that time. Results from the bookkeeping method are available from 1850 to 2010 .

\subsubsection{Fire-based method}

LUC-associated $\mathrm{CO}_{2}$ emissions calculated from satellitebased fire activity in tropical forest areas (van der Werf et al., 2010) provide information on emissions due to tropical deforestation and degradation that are complementary to the bookkeeping approach. They do not provide a direct estimate of $E_{\mathrm{LUC}}$ as they do not include non-combustion processes such as respiration, wood harvest, wood products, and forest regrowth. Legacy emissions such as decomposition from onground debris and soils are not included in this method either. However, fire estimates provide some insight into the year-to- year variations in the sub-component of the total $E_{\mathrm{LUC}}$ flux that result from immediate $\mathrm{CO}_{2}$ emissions during deforestation caused, for example, by the interactions between climate and human activity (e.g. there is more burning and clearing of forests in dry years) that are not represented by other methods. The "deforestation fire emissions" assume an important role of fire in removing biomass in the deforestation process, and thus can be used to infer gross instantaneous $\mathrm{CO}_{2}$ emissions from deforestation using satellite-derived data on fire activity in regions with active deforestation. The method requires information on the fraction of total area burned associated with deforestation versus other types of fires, and this information can be merged with information on biomass stocks and the fraction of the biomass lost in a deforestation fire to estimate $\mathrm{CO}_{2}$ emissions. The satellite-based deforestation fire emissions are limited to the tropics, where fires result mainly from human activities. Tropical deforestation is the largest and most variable single contributor to $E_{\mathrm{LUC}}$.

Fire emissions associated with deforestation and tropical peat burning are based on the Global Fire Emissions Database (GFED) described in van der Werf et al. (2010) but with updated burned area (Giglio et al., 2013) as well as burned area from relatively small fires that are detected by satellite as thermal anomalies but not mapped by the burnedarea approach (Randerson et al., 2012). The burned-area information is used as input data in a modified version of the satellite-driven Carnegie-Ames-Stanford Approach (CASA) biogeochemical model to estimate carbon emissions associated with fires, keeping track of what fraction of fire emissions was due to deforestation (see van der Werf et al., 2010). The CASA model uses different assumptions to compute 
Table 6. References for the process models and data products included in Figs. 6-8.

\begin{tabular}{|c|c|c|}
\hline $\begin{array}{l}\text { Model/data } \\
\text { name }\end{array}$ & Reference & Change from Le Quéré et al. (2013) \\
\hline \multicolumn{3}{|c|}{ Dynamic global vegetation models } \\
\hline CABLE2.0 & Zhang et al. (2013) & $\begin{array}{l}\text { Updated model from CABLE1.4 (Wang et al., 2011) to include full carbon, nitrogen, and phos- } \\
\text { phorus cycle (Wang et al., 2010) and land cover and land-cover change. }\end{array}$ \\
\hline CLM4.5BGC $^{\mathrm{a}}$ & Oleson et al. (2013) & $\begin{array}{l}\text { Updated model from CLM4.0CN to CLM4.5BGC. Major changes include revised photosynthe- } \\
\text { sis, slower turnover times for decomposition of litter and SOM, vertically resolved soil biogeo- } \\
\text { chemistry, revised soil denitrification and nitrification, new fire model, and revised frozen-soil } \\
\text { hydrology. As shown in Koven et al. (2013), these changes collectively bring model into better } \\
\text { agreement with 20th century C budget. }\end{array}$ \\
\hline ISAM & Jain et al. $(2013)^{\mathrm{b}}$ & Not applicable \\
\hline JULES $\mathrm{c}$ & Clark et al. (2011) $)^{\mathrm{d}}$ & $\begin{array}{l}\text { Updated model from JULESv1 (Cox et al., 2000) to JULESv3.2 as configured in the latest } \\
\text { generation ESM-HadGEM2-ES (Collins et al., 2011). Higher resolution }(1.875 \times 1.25) \text { and with } \\
\text { an improved snow scheme, multi-pool soil carbon model, updated representation of land-use } \\
\text { change. }\end{array}$ \\
\hline LPJ-GUESS & Smith et al. (2001) & Not applicable \\
\hline $\mathrm{LPJ}^{\mathrm{e}}$ & Sitch et al. (2003) & $\begin{array}{l}\text { Decreased LPJ wood harvest efficiency so that } 50 \% \text { of biomass was removed off-site compared } \\
\text { to } 85 \% \text { used in the } 2012 \text { budget. Residue management of managed grasslands increased so that } \\
100 \% \text { of harvested grass enters litter pool. }\end{array}$ \\
\hline LPX & Stocker et al. (2013a) & Addition of $\mathrm{C}-\mathrm{N}$ cycle coupling. \\
\hline ORCHIDEE & Krinner et al. (2005) & $\begin{array}{l}\text { Revised parameters values for photosynthetic capacity for boreal forests (following assimilation } \\
\text { of FLUXNET data), updated parameters values for stem allocation, maintenance respiration } \\
\text { and biomass export for tropical forests (based on literature), and } \mathrm{CO}_{2} \text { down-regulation process } \\
\text { added to photosynthesis. }\end{array}$ \\
\hline VEGAS & Zeng et al. $(2005)^{\mathrm{f}}$ & Improved wetland and permafrost parameterisations, high-latitude temperature dependence \\
\hline VISIT & Kato et al. (2013) & $\begin{array}{l}\text { Wood harvest flux is added to } E_{\mathrm{LUC}} \text {, and the loss of additional sink capacity is also included in } \\
\text { the } E_{\mathrm{LUC}} \text { due to the methodological change of using coordinated DGVM experiments. }\end{array}$ \\
\hline \multicolumn{3}{|c|}{ Data products for land-use-change emissions } \\
\hline $\begin{array}{l}\text { Bookkeeping } \\
\text { Fire-based } \\
\text { emissions }\end{array}$ & $\begin{array}{l}\text { Houghton et al. (2012) } \\
\text { van der Werf et al. (2010) }\end{array}$ & $\begin{array}{l}\text { No change } \\
\text { No change }\end{array}$ \\
\hline \multicolumn{3}{|c|}{ Ocean biogeochemistry models } \\
\hline $\begin{array}{l}\text { NEMO- } \\
\text { PlankTOM5 }\end{array}$ & Buitenhuis et al. $(2010)^{\mathrm{h}}$ & No change \\
\hline $\begin{array}{l}\text { NEMO- } \\
\text { PISCES } \\
\text { (IPSL) }^{i}\end{array}$ & Aumont and Bopp (2006) & No change \\
\hline CCSM-BEC & Doney et al. (2009) & No change \\
\hline $\begin{array}{l}\text { MICOM- } \\
\text { HAMOCC }\end{array}$ & Assmann et al. $(2010)^{\mathrm{j}}$ & No change \\
\hline $\begin{array}{l}\text { MPIOM- } \\
\text { HAMOCC }\end{array}$ & Ilyina et al. (2013) & No change \\
\hline $\begin{array}{l}\text { NEMO- } \\
\text { PISCES } \\
\text { (CNRM) }\end{array}$ & Séférian et al. $(2013)^{\mathrm{k}}$ & Not applicable \\
\hline CSIRO & Oke et al. (2013) & Not applicable \\
\hline
\end{tabular}

\begin{tabular}{lcl}
\hline \multicolumn{2}{l}{ Data products for ocean $\mathrm{CO}_{2}$ sink } \\
\hline Landschützer & Landschützer et al. (2014) & Not applicable \\
Park & Park et al. (2010) & No change \\
Rödenbeck & Rödenbeck et al. $(2014)^{\mathrm{m}}$ & No change
\end{tabular}

Atmospheric inversions for total $\mathrm{CO}_{2}$ fluxes (land-use change + land + ocean $\mathrm{CO}_{2}$ sinks)

\begin{tabular}{|c|c|c|}
\hline Peters & Peters et al. (2010) & Not applicable \\
\hline Rödenbeck & Rödenbeck et al. (2003) & Not applicable \\
\hline MACC $^{\mathrm{n}}$ & Chevallier et al. (2005) & Not applicable \\
\hline
\end{tabular}


decay functions compared to the bookkeeping method, and does not include historical emissions or regrowth from landuse change prior to the availability of satellite data. Comparing coincident $\mathrm{CO}$ emissions and their atmospheric fate with satellite-derived $\mathrm{CO}$ concentrations allows for some validation of this approach (e.g. van der Werf et al., 2008). Results from the fire-based method to estimate LUC emissions anomalies added to the bookkeeping mean $E_{\mathrm{LUC}}$ estimate are available from 1997 to 2013. Our combination of LUC CO 2 emissions where the variability of annual $\mathrm{CO}_{2}$ deforestation emissions is diagnosed from fires assumes that year-to-year variability is dominated by variability in deforestation.

\subsubsection{Dynamic global vegetation models (DGVMs)}

LUC $\mathrm{CO}_{2}$ emissions have been estimated using an ensemble of seven DGVMs. New model experiments up to year 2013 have been coordinated by the project "Trends and drivers of the regional-scale sources and sinks of carbon dioxide" (TRENDY; http://dgvm.ceh.ac.uk/node/9). We use only models that have estimated LUC $\mathrm{CO}_{2}$ emissions and the terrestrial residual sink following the TRENDY protocol (see Sect. 2.5.2), thus providing better consistency in the assessment of the causes of carbon fluxes on land. Models use their latest configurations, summarised in Tables 5 and 6.

The DGVMs were forced with historical changes in landcover distribution, climate, atmospheric $\mathrm{CO}_{2}$ concentration, and $\mathrm{N}$ deposition. As further described below, each historical DGVM simulation was repeated with a time-invariant pre-industrial land-cover distribution, allowing for estimation of, by difference with the first simulation, the dynamic evolution of biomass and soil carbon pools in response to prescribed land-cover change. All DGVMs represent deforestation and (to some extent) regrowth, the most important components of $E_{\mathrm{LUC}}$, but they do not represent all processes resulting directly from human activities on land (Table 5). DGVMs represent processes of vegetation growth and mortality, as well as decomposition of dead organic matter associated with natural cycles, and include the vegetation and soil carbon response to increasing atmospheric $\mathrm{CO}_{2}$ levels and to climate variability and change. In addition, four models explicitly simulate the coupling of $\mathrm{C}$ and $\mathrm{N}$ cycles and account for atmospheric $\mathrm{N}$ deposition (Table 5). The DGVMs are independent of the other budget terms except for their use of atmospheric $\mathrm{CO}_{2}$ concentration to calculate the fertilisation effect of $\mathrm{CO}_{2}$ on primary production.

The DGVMs used a consistent land-use-change data set (Hurtt et al., 2011), which provided annual, half-degree, fractional data on cropland, pasture, and primary and secondary vegetation, as well as all underlying transitions between landuse states, including wood harvest and shifting cultivation. This data set used the HYDE (Klein Goldewijk et al., 2011) spatially gridded maps of cropland, pasture, and ice/water fractions of each grid cell as an input. The HYDE data are based on annual FAO statistics of change in agricultural area
(FAOSTAT, 2010). For the years 2011, 2012, and 2013, the HYDE data set was extrapolated by country for pastures and cropland separately based on the trend in agricultural area over the previous 5 years. The HYDE data set is independent of the data set used in the bookkeeping method (Houghton, 2003 , and updates), which is based primarily on forest area change statistics (FAO, 2010). Although the Hurtt land-usechange data set indicates whether land-use changes occur on forested or non-forested land, typically only the changes in agricultural areas are used by the models and are implemented differently within each model (e.g. an increased cropland fraction in a grid cell can be at the expense of either grassland or forest, the latter resulting in deforestation; land-cover fractions of the non-agricultural land differ between models). Thus the DGVM forest area and forest area change over time is not consistent with the Forest Resource Assessment of the FAO forest area data used for the bookkeeping model to calculate $E_{\mathrm{LUC}}$. Similarly, model-specific assumptions are applied to convert deforested biomass or deforested area, and other forest product pools, into carbon in some models (Table 5).

The DGVM model runs were forced by either 6-hourly CRU-NCEP or monthly temperature, precipitation, and cloud cover fields (transformed into incoming surface radiation) based on observations and provided on a $0.5^{\circ} \times 0.5^{\circ}$ grid and updated to 2013 (CRU TS3.22; Harris et al., 2014). The forcing data include both gridded observations of climate and global atmospheric $\mathrm{CO}_{2}$, which change over time (Dlugokencky and Tans, 2014), and $\mathrm{N}$ deposition (as used in 4 models, Table 5; Lamarque et al., 2010). $E_{\mathrm{LUC}}$ is diagnosed in each model by the difference between a model simulation with prescribed historical land-cover change and a simulation with constant, pre-industrial land-cover distribution. Both simulations were driven by changing atmospheric $\mathrm{CO}_{2}$, climate, and, in some models, $\mathrm{N}$ deposition over the period 1860-2013. Using the difference between these two DGVM simulations to diagnose $E_{\mathrm{LUC}}$ is not consistent with the definition of $E_{\mathrm{LUC}}$ in the bookkeeping method (Gasser and Ciais, 2013; Pongratz et al., 2014). The DGVM approach to diagnose land-use-change $\mathrm{CO}_{2}$ emissions would be expected to produce systematically higher $E_{\mathrm{LUC}}$ emissions than the bookkeeping approach if all the parameters of the two approaches were the same (which is not the case). Here, given the different input data of DGVMs and the bookkeeping approach, this systematic difference cannot be quantified.

\subsubsection{Uncertainty assessment for $E_{\mathrm{LUC}}$}

Differences between the bookkeeping, the addition of firebased interannual variability to the bookkeeping, and DGVM methods originate from three main sources: the land-coverchange data set, the different approaches used in models, and the different processes represented (Table 5). We examine the results from the seven DGVM models and of the bookkeeping method to assess the uncertainty in $E_{\text {LUC }}$. 
Table 7. Comparison of results from the bookkeeping method and budget residuals with results from the DGVMs and inverse estimates for the periods 1960-1969, 1970-1979, 1980-1989, 1990-1999, 2000-2009, last decade, and last year available. All values are in GtC yr ${ }^{-1}$. The DGVM uncertainties represents $\pm 1 \sigma$ of results from the nine individual models; for the inverse models all three results are given where available.

\begin{tabular}{|c|c|c|c|c|c|c|c|}
\hline \multicolumn{8}{|c|}{ Mean $\left(\mathrm{GtC} \mathrm{yr}^{-1}\right)$} \\
\hline & 1960-1969 & 1970-1979 & 1980-1989 & 1990-1999 & 2000-2009 & 2004-2013 & 2013 \\
\hline \multicolumn{8}{|c|}{ Land-use-change emissions ( $\left.E_{\mathrm{LUC}}\right)$} \\
\hline Bookkeeping method & $1.5 \pm 0.5$ & $1.3 \pm 0.5$ & $1.4 \pm 0.5$ & $1.6 \pm 0.5$ & $1.0 \pm 0.5$ & $0.9 \pm 0.5$ & $0.9 \pm 0.5$ \\
\hline DGVMs & $1.3 \pm 0.5$ & $1.2 \pm 0.6$ & $1.3 \pm 0.6$ & $1.8 \pm 0.9$ & $1.1 \pm 0.7$ & $1.0 \pm 0.7$ & $0.9 \pm 0.6$ \\
\hline \multicolumn{8}{|c|}{ Residual terrestrial sink ( $\left.S_{\text {LAND }}\right)$} \\
\hline Budget residual & $1.8 \pm 0.7$ & $1.8 \pm 0.8$ & $1.6 \pm 0.8$ & $2.7 \pm 0.7$ & $2.4 \pm 0.8$ & $2.9 \pm 0.8$ & $2.5 \pm 0.9$ \\
\hline DGVMs & $1.1 \pm 0.7$ & $2.0 \pm 0.8$ & $1.6 \pm 1.0$ & $2.1 \pm 0.9$ & $2.4 \pm 0.9$ & $2.5 \pm 1.0$ & $2.4 \pm 1.2$ \\
\hline \multicolumn{8}{|c|}{ Total land fluxes $\left(E_{\mathrm{LUC}}+S_{\mathrm{LAND}}\right)$} \\
\hline Budget $\left(E_{\mathrm{FF}}-G_{\mathrm{ATM}}-S_{\text {OCEAN }}\right)$ & $0.2 \pm 0.5$ & $0.4 \pm 0.6$ & $0.2 \pm 0.6$ & $1.1 \pm 0.6$ & $1.5 \pm 0.6$ & $2.0 \pm 0.7$ & $1.6 \pm 0.7$ \\
\hline DGVMs & $-0.3 \pm 0.8$ & $0.7 \pm 0.8$ & $0.1 \pm 0.7$ & $0.1 \pm 1.0$ & $1.2 \pm 0.9$ & $1.4 \pm 1.0$ & $1.5 \pm 1.2$ \\
\hline Inversions $(\mathrm{P} / \mathrm{R} / \mathrm{C})$ & $-/-/-$ & $-1-1-$ & $-/ 0.2^{*} / 0.7^{*}$ & $-/ 1.1 * / 1.7^{*}$ & $-/ 1.5^{*} / 2.4^{*}$ & $1.7^{*} / 1.9^{*} / 3.1^{*}$ & $1.3^{*} / 2.2^{*} / 2.7^{*}$ \\
\hline
\end{tabular}

The uncertainties in the annual $E_{\mathrm{LUC}}$ estimates are examined using the standard deviation across models, which ranged from 0.3 to $1.1 \mathrm{GtC} \mathrm{yr}^{-1}$, with an average of $0.7 \mathrm{GtC} \mathrm{yr}^{-1}$ from 1959 to 2013 (Table 7). The mean of the multi-model $E_{\mathrm{LUC}}$ estimates is the same as the mean of the bookkeeping estimate from the budget (Eq. 1) at $1.3 \mathrm{GtC}$ for 1959 to 2010. The multi-model mean and bookkeeping method differ by less than $0.5 \mathrm{GtC} \mathrm{yr}^{-1}$ over $90 \%$ of the time. Based on this comparison, we assess that an uncer-

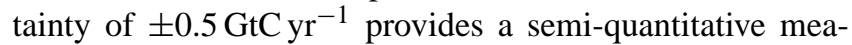
sure of uncertainty for annual emissions and reflects our best value judgment that there is at least $68 \%$ chance $( \pm 1 \sigma)$ that the true LUC emission lies within the given range, for the range of processes considered here. This is consistent with the uncertainty analysis of Houghton et al. (2012), which partly reflects improvements in data on forest area change using data, and partly more complete understanding and representation of processes in models. The uncertainties in the decadal mean estimates from the DGVM ensemble are likely correlated between decades, and thus we apply the annual uncertainty as a measure of the decadal uncertainty. The correlations between decades come from (1) common biases in system boundaries (e.g. not counting forest degradation in some models); (2) common definition for the calculation of $E_{\mathrm{LUC}}$ from the difference of simulations with and without LUC (a source of bias vs. the unknown truth); and (3) common and uncertain land-cover-change input data which also cause a bias (though if a different input data set is used each decade, decadal fluxes from DGVMs may be partly decorrelated); and (4) model structural errors (e.g. systematic errors in biomass stocks). In addition, errors arising from uncertain DGVM parameter values would be random, but they are not accounted for in this study, since no DGVM provided an ensemble of runs with perturbed parameters.

Prior to 1959 , the uncertainty in $E_{\mathrm{LUC}}$ is taken as $\pm 33 \%$, which is the ratio of uncertainty to mean from the $1960 \mathrm{~s}$ (Table 7), the first decade available. This ratio is consistent with the mean standard deviation of DGMVs' LUC emissions over 1870-1958 (0.41 GtC) over the multi-model mean (0.94 GtC).

\subsection{Atmospheric $\mathrm{CO}_{2}$ growth rate $\left(G_{\text {ATM }}\right)$}

\section{Global atmospheric $\mathrm{CO}_{2}$ growth rate estimates}

The atmospheric $\mathrm{CO}_{2}$ growth rate is provided by the US National Oceanic and Atmospheric Administration Earth System Research Laboratory (NOAA/ESRL; Dlugokencky and Tans, 2014), which is updated from Ballantyne et al. (2012). For the 1959-1980 period, the global growth rate is based on measurements of atmospheric $\mathrm{CO}_{2}$ concentration averaged from the Mauna Loa and South Pole stations, as observed by the $\mathrm{CO}_{2}$ Program at Scripps Institution of Oceanography (Keeling et al., 1976). For the 1980-2012 time period, the global growth rate is based on the average of multiple stations selected from the marine boundary layer sites with well-mixed background air (Ballantyne et al., 2012), after fitting each station with a smoothed curve as a function of time, and averaging by latitude band (Masarie and Tans, 1995). The annual growth rate is estimated by Dlugokencky and Tans (2014) from atmospheric $\mathrm{CO}_{2}$ concentration by taking the average of the most recent DecemberJanuary months corrected for the average seasonal cycle and subtracting this same average 1 year earlier. The growth rate

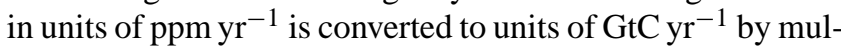


tiplying by a factor of $2.120 \mathrm{GtC} \mathrm{ppm}^{-1}$ (Prather et al., 2012) for consistency with the other components.

The uncertainty around the annual growth rate based on the multiple stations data set ranges between 0.11 and $0.72 \mathrm{GtC} \mathrm{yr}^{-1}$, with a mean of $0.60 \mathrm{GtC} \mathrm{yr}^{-1}$ for $1959-1980$ and $0.19 \mathrm{GtC} \mathrm{yr}^{-1}$ for 1980-2013, when a larger set of stations were available (Dlugokencky and Tans, 2014). It is based on the number of available stations, and thus takes into account both the measurement errors and data gaps at each station. This uncertainty is larger than the uncertainty of $\pm 0.1 \mathrm{GtC} \mathrm{yr}^{-1}$ reported for decadal mean growth rate by the IPCC because errors in annual growth rate are strongly anti-correlated in consecutive years, leading to smaller errors for longer timescales. The decadal change is computed from the difference in concentration 10 years apart based on a measurement error of $0.35 \mathrm{ppm}$. This error is based on offsets between NOAA/ESRL measurements and those of the World Meteorological Organization World Data Center for Greenhouse Gases (NOAA/ESRL, 2014) for the start and end points (the decadal change uncertainty is the $\sqrt{\left(2(0.35 \mathrm{ppm})^{2}\right)}(10 \mathrm{yr})^{-1}$ assuming that each yearly measurement error is independent). This uncertainty is also used in Table 8.

The contribution of anthropogenic $\mathrm{CO}$ and $\mathrm{CH}_{4}$ is neglected from the global carbon budget (see Sect. 2.7.1). We assign a high confidence to the annual estimates of $G_{\text {ATM }}$ because they are based on direct measurements from multiple and consistent instruments and stations distributed around the world (Ballantyne et al., 2012).

In order to estimate the total carbon accumulated in the atmosphere since 1750 or 1870 , we use an atmospheric $\mathrm{CO}_{2}$ concentration of $277 \pm 3$ or $288 \pm 3 \mathrm{ppm}$, respectively, based on a cubic spline fit to ice core data (Joos and Spahni, 2008). The uncertainty of $\pm 3 \mathrm{ppm}$ (converted to $\pm 1 \sigma$ ) is taken directly from the IPCC's assessment (Ciais et al., 2013). Typical uncertainties in the atmospheric growth rate from ice core data are $\pm 1-1.5 \mathrm{GtC}$ decade $^{-1}$ as evaluated from the Law Dome data (Etheridge et al., 1996) for individual 20-year intervals over the period from 1870 to 1960 (Bruno and Joos, 1997).

\subsection{Ocean $\mathrm{CO}_{2}$ sink}

Estimates of the global ocean $\mathrm{CO}_{2}$ sink are based on a combination of a mean $\mathrm{CO}_{2}$ sink estimate for the 1990s from observations and a trend and variability in the ocean $\mathrm{CO}_{2}$ sink for 1959-2013 from seven global ocean biogeochemistry models. We use three observation-based estimated of

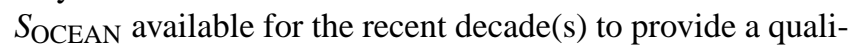
tative assessment of confidence in the reported results.

\subsubsection{Observation-based estimates}

A mean ocean $\mathrm{CO}_{2}$ sink of $2.2 \pm 0.4 \mathrm{GtC} \mathrm{yr}^{-1}$ for the $1990 \mathrm{~s}$ was estimated by the IPCC (Denman et al., 2007) based on indirect observations and their spread: ocean-land $\mathrm{CO}_{2}$ sink partitioning from observed atmospheric $\mathrm{O}_{2} / \mathrm{N}_{2}$ concentration trends (Keeling et al., 2011; Manning and Keeling, 2006), an oceanic inversion method constrained by ocean biogeochemistry data (Mikaloff Fletcher et al., 2006), and a method based on penetration time scale for CFCs (McNeil et al., 2003). This is comparable with the sink of $2.0 \pm 0.5 \mathrm{GtC} \mathrm{yr}^{-1}$ estimated by Khatiwala et al. (2013) for the $1990 \mathrm{~s}$, and with the sink of 1.9 to 2.5 estimated from a range of methods for the period 1990-2009 (Wanninkhof et al., 2013), with uncertainties ranging from \pm 0.3 to $\pm 0.7 \mathrm{GtC} \mathrm{yr}^{-1}$. The most direct way to estimate the observation-based ocean sink is from the product of (seaair $p \mathrm{CO}_{2}$ difference $) \times($ gas transfer coefficient). Estimates based on sea-air $p \mathrm{CO}_{2}$ are fully consistent with indirect observations (Zeng et al., 2005), but their uncertainty is larger mainly due to difficulty in capturing complex turbulent processes in the gas transfer coefficient (Sweeney et al., 2007).

Two of the three observation-based estimates computed the interannual variability in the ocean $\mathrm{CO}_{2}$ sink using interpolated measurements of surface ocean fugacity of $\mathrm{CO}_{2}$ ( $p \mathrm{CO}_{2}$ corrected for the non-ideal behaviour of the gas; Pfeil et al., 2013). The measurements were from the Surface Ocean $\mathrm{CO}_{2}$ Atlas (SOCAT v2; Bakker et al., 2014), which contains data to the end of 2011. This was extended with 2.4 million additional measurements from 2012 and 2013 from all basins (see data attribution table in Appendix A), submitted to SOCAT but not yet fully quality-controlled following standard SOCAT procedures. Revisions and corrections to measurements from before 2012 were also included where they were available. All new data were subjected to an automated quality control system to detect and remove the most obvious errors (e.g. incorrect reporting of metadata such as position, wrong units, clearly unrealistic data). The combined SOCAT v2 and preliminary 2012-2013 data were implemented in an inversion method (Rödenbeck et al., 2013) and a combined self-organising map and feed-forward neural network (Landschützer et al., 2014). The observationbased estimates were corrected to remove a background (not part of the anthropogenic ocean flux) ocean source of $\mathrm{CO}_{2}$ to the atmosphere of $0.45 \mathrm{GtC} \mathrm{yr}^{-1}$ from river input to the ocean (Jacobson et al., 2007) so as to make them comparable to $S_{\text {OCEAN }}$, which only represents the annual uptake of anthropogenic $\mathrm{CO}_{2}$ by the ocean.

We also compare the results with those of Park et al. (2010) based on regional correlations between surface temperature and $p \mathrm{CO}_{2}$, changes in surface temperature observed by satellite, and wind speed estimates also from satellite data for 1990-2009 (Atlas et al., 2011). The product of Park et al. (2010) provides a data-based assessment of the interannual variability combined with a model-based assessment of the trend and mean in $S_{\text {OCEAN. Several other data-based }}$ products are in preparation (e.g. Zeng et al., 2014) and the comparison with data products should help constrain the ocean $\mathrm{CO}_{2}$ sink in the future. 
Table 8. Decadal mean in the five components of the anthropogenic $\mathrm{CO}_{2}$ budget for the periods 1960-1969, 1970-1979, 1980-1989, 19901999, 2000-2009, last decade, and last year available. All values are in $\mathrm{GtC} \mathrm{yr}^{-1}$. All uncertainties are reported as $\pm 1 \sigma$. A data set containing data for each year during 1959-2013 is available at http://cdiac.ornl.gov/GCP/carbonbudget/2014/. Please follow the terms of use and cite the original data sources as specified on the data set.

\begin{tabular}{|c|c|c|c|c|c|c|c|}
\hline & \multicolumn{7}{|c|}{ Mean $\left(\mathrm{GtC} \mathrm{yr}^{-1}\right)$} \\
\hline & 1960-1969 & 1970-1979 & 1980-1989 & 1990-1999 & 2000-2009 & 2004-2013 & 2013 \\
\hline Emissions & & & & & & & \\
\hline $\begin{array}{l}\text { Fossil fuel combustion and } \\
\text { cement production }\left(E_{\mathrm{FF}}\right)\end{array}$ & $3.1 \pm 0.2$ & $4.7 \pm 0.2$ & $5.5 \pm 0.3$ & $6.4 \pm 0.3$ & $7.8 \pm 0.4$ & $8.9 \pm 0.4$ & $9.9 \pm 0.5$ \\
\hline $\begin{array}{l}\text { Land-use-change emissions } \\
\left(E_{\text {LUC }}\right)\end{array}$ & $1.5 \pm 0.5$ & $1.3 \pm 0.5$ & $1.4 \pm 0.5$ & $1.6 \pm 0.5$ & $1.0 \pm 0.5$ & $0.9 \pm 0.5$ & $0.9 \pm 0.5$ \\
\hline $\begin{array}{l}\text { Partitioning } \\
\text { Atmospheric growth rate } \\
\left(G_{\mathrm{ATM}}\right)\end{array}$ & $1.7 \pm 0.1$ & $2.8 \pm 0.1$ & $3.4 \pm 0.1$ & $3.1 \pm 0.1$ & $4.0 \pm 0.1$ & $4.3 \pm 0.1$ & $5.4 \pm 0.2$ \\
\hline Ocean sink $\left(S_{\text {OCEAN }}\right)^{*}$ & $1.1 \pm 0.5$ & $1.5 \pm 0.5$ & $1.9 \pm 0.5$ & $2.2 \pm 0.5$ & $2.4 \pm 0.5$ & $2.6 \pm 0.5$ & $2.9 \pm 0.5$ \\
\hline $\begin{array}{l}\text { Residual terrestrial sink } \\
\left(S_{\text {LAND }}\right)\end{array}$ & $1.8 \pm 0.7$ & $1.8 \pm 0.8$ & $1.6 \pm 0.8$ & $2.7 \pm 0.8$ & $2.4 \pm 0.8$ & $2.9 \pm 0.8$ & $2.5 \pm 0.9$ \\
\hline
\end{tabular}

* The uncertainty in $S_{\text {OCEAN }}$ for the 1990 s is directly based on observations, while that for other decades combines the uncertainty from observations with the model spread (Sect. 2.4.3)

We use the data-based product of Khatiwala et al. (2009), updated by Khatiwala et al. (2013), to estimate the anthropogenic carbon accumulated in the ocean during 17651958 (60.2 GtC) and 1870-1958 (47.5 GtC), and assume an oceanic uptake of $0.4 \mathrm{GtC}$ for $1750-1765$, for which time no data are available, based on the mean uptake during 17651770. The estimate of Khatiwala et al. (2009) is based on regional disequilibrium between surface $p \mathrm{CO}_{2}$ and atmospheric $\mathrm{CO}_{2}$, and a Green's function utilising transient ocean tracers like CFCs and ${ }^{14} \mathrm{C}$ to ascribe changes through time. It does not include changes associated with changes in ocean circulation, temperature and climate, but these are thought to be small over the time period considered here (Ciais et al., 2013). The uncertainty in cumulative uptake of $\pm 20 \mathrm{GtC}$ (converted to $\pm 1 \sigma$ ) is taken directly from the IPCC's review of the literature (Rhein et al., 2013), or about $\pm 30 \%$ for the annual values (Khatiwala et al., 2009).

\subsubsection{Global ocean biogeochemistry models}

The trend in the ocean $\mathrm{CO}_{2}$ sink for 1959-2013 is computed using a combination of seven global ocean biogeochemistry models (Table 6). The models represent the physical, chemical and biological processes that influence the surface ocean concentration of $\mathrm{CO}_{2}$ and thus the air-sea $\mathrm{CO}_{2}$ flux. The models are forced by meteorological reanalysis and atmospheric $\mathrm{CO}_{2}$ concentration data available for the entire time period. Models do not include the effects of anthropogenic changes in nutrient supply. They compute the air-sea flux of $\mathrm{CO}_{2}$ over grid boxes of 1 to $4^{\circ}$ in latitude and longitude. The ocean $\mathrm{CO}_{2}$ sink for each model is normalised to the observa- tions by dividing the annual model values by their observed average over 1990-1999 (obtained from Keeling et al., 2011; Manning and Keeling, 2006; McNeil et al., 2003; Mikaloff Fletcher et al., 2006) and multiplying this by the observationbased estimate of $2.2 \mathrm{GtC} \mathrm{yr}^{-1}$. The ocean $\mathrm{CO}_{2}$ sink for each year $(t)$ is therefore

$S_{\text {OCEAN }}(t)=\frac{1}{n} \sum_{m=1}^{m=n} \frac{S_{\text {OCEAN }}^{m}(t)}{S_{\text {OCEAN }}^{m}(1990-1999)} \times 2.2$,

where $n$ is the number of models. This normalisation ensures that the ocean $\mathrm{CO}_{2}$ sink for the global carbon budget is based on observations, whereas the trends and annual values in $\mathrm{CO}_{2}$ sinks are from model estimates. The normalisation based on a ratio assumes that if models over- or underestimate the sink in the 1990s, it is primarily due to the process of diffusion, which depends on the gradient of $\mathrm{CO}_{2}$. Thus a ratio is more appropriate than an offset as it takes into account the time dependence of $\mathrm{CO}_{2}$ gradients in the ocean. The mean uncorrected ocean $\mathrm{CO}_{2}$ sink from the seven models for 1990-1999 ranges between 1.5 and $2.6 \mathrm{GtC} \mathrm{yr}^{-1}$, with a multi-model mean of $1.9 \mathrm{GtC} \mathrm{yr}^{-1}$.

\subsubsection{Uncertainty assessment for $S_{\text {OCEAN }}$}

The uncertainty around the mean ocean sink of anthropogenic $\mathrm{CO}_{2}$ was quantified by Denman et al. (2007) for the 1990s (see Sect. 2.4.1). To quantify the uncertainty around annual values, we examine the standard deviation of the normalised model ensemble. We use further information from the three data-based products to assess the confidence level. The average standard deviation of the ocean model 
ensemble is $0.15 \mathrm{GtC} \mathrm{yr}^{-1}$ during 1980-2010 (with a maximum of 0.22), but it increases as the model ensemble goes back in time, with a standard deviation of $0.28 \mathrm{GtC} \mathrm{yr}^{-1}$ across models in the 1960s. We estimate that the uncertainty in the annual ocean $\mathrm{CO}_{2}$ sink is about $\pm 0.5 \mathrm{GtC} \mathrm{yr}^{-1}$ from the fractional uncertainty in the data uncertainty of $\pm 0.4 \mathrm{GtC} \mathrm{yr}^{-1}$ and standard deviation across models of up to $\pm 0.28 \mathrm{GtC} \mathrm{yr}^{-1}$, reflecting both the uncertainty in the mean sink from observations during the 1990s (Denman et al., 2007; Sect. 2.4.1) and in the interannual variability as assessed by models.

We examine the consistency between the variability of the model-based and the data-based products to assess confidence in $S_{\text {OCEAN. }}$ The interannual variability of the ocean fluxes (quantified as the standard deviation) of the three data-based estimates for 1990-2009 (when they overlap) is $\pm 0.37 \mathrm{GtC} \mathrm{yr}^{-1}$ (Rödenbeck et al., 2014), $\pm 0.25 \mathrm{GtC} \mathrm{yr}^{-1}$ (Landschützer et al., 2014), and $\pm 0.14 \mathrm{GtC} \mathrm{yr}^{-1}$ (Park et al., 2010), compared to $\pm 0.18 \mathrm{GtC} \mathrm{yr}^{-1}$ for the model mean. The standard deviation includes a component of trend and decadal variability in addition to interannual variability, and their relative influence differs across estimates. The phase is generally consistent between estimates, with a higher ocean $\mathrm{CO}_{2}$ sink during El Niño events. The annual data-based estimates correlate with the ocean $\mathrm{CO}_{2}$ sink estimated here with a correlation of $r=0.36$ ( 0.0 to 0.49 for individual models), $r=0.73$ ( 0.54 to 0.68 ), and $r=0.64$ (0.12 to 0.71 ) for the data-based estimates of Rödenbeck et al. (2014), Landschützer et al. (2014), and Park et al. (2010), respectively (simple linear regression), but their mutual correlation ranges between 0.24 and 0.31 only. The use of annual data for the correlation may reduce the strength of the relationship because the dominant source of variability associated with El Niño events is less than 1 year. We assess a medium confidence level to the annual ocean $\mathrm{CO}_{2}$ sink and its uncertainty because they are based on multiple lines of evidence, and the results are consistent in that the interannual variability in the model and data-based estimates are all generally small compared to the variability in atmospheric $\mathrm{CO}_{2}$ growth rate. Nevertheless the various results do not show agreement in interannual variability on the global scale or for the relative roles of the annual and decadal variability compared to the trend.

\subsection{Terrestrial $\mathrm{CO}_{2}$ sink}

The difference between the fossil fuel $\left(E_{\mathrm{FF}}\right)$ and LUC net emissions $\left(E_{\mathrm{LUC}}\right)$, the growth rate in atmospheric $\mathrm{CO}_{2}$ concentration $\left(G_{\mathrm{ATM}}\right)$, and the ocean $\mathrm{CO}_{2}$ sink ( $\left.S_{\mathrm{OCEAN}}\right)$ is attributable to the net sink of $\mathrm{CO}_{2}$ in terrestrial vegetation and soils $\left(S_{\mathrm{LAND}}\right)$, within the given uncertainties. Thus, this sink can be estimated as the residual of the other terms in the mass balance budget, as well as directly calculated using DGVMs; alternatively, it can be estimated from inverse models that close a spatio-temporally explicit form of the mass balance in Eq. (1). The residual land sink ( $\left.S_{\text {LAND }}\right)$ is thought to be in part because of the fertilising effect of rising atmospheric $\mathrm{CO}_{2}$ on plant growth, $\mathrm{N}$ deposition, and effects of climate change such as the lengthening of the growing season in northern temperate and boreal areas. $S_{\text {LAND }}$ does not include gross land sinks directly resulting from LUC (e.g. regrowth of vegetation) as these are estimated to be part of the net landuse flux $\left(E_{\mathrm{LUC}}\right)$. System boundaries make it difficult to exactly attribute $\mathrm{CO}_{2}$ fluxes on land between $S_{\mathrm{LAND}}$ and $E_{\mathrm{LUC}}$ (Erb et al., 2013), and by design most of the uncertainties in our method are allocated to $S_{\text {LAND }}$ for those processes that are poorly known or represented in models.

\subsubsection{Residual of the budget}

For 1959-2013, the terrestrial carbon sink was estimated from the residual of the other budget terms by rearranging Eq. (1):

$S_{\mathrm{LAND}}=E_{\mathrm{FF}}+E_{\mathrm{LUC}}-\left(G_{\mathrm{ATM}}+S_{\mathrm{OCEAN}}\right)$.

The uncertainty in $S_{\text {LAND }}$ is estimated annually from the root sum of squares of the uncertainty in the right-hand terms assuming the errors are not correlated. The uncertainty averages to $\pm 0.8 \mathrm{GtC} \mathrm{yr}^{-1}$ over $1959-2013$ (Table 7). S SAND estimated from the residual of the budget includes, by definition, all the missing processes and potential biases in the other components of Eq. (8).

\subsubsection{DGVMs}

A comparison of the residual calculation of $S_{\text {LAND }}$ in Eq. (8) with estimates from DGVMs as used to estimate $E_{\text {LUC }}$ in Sect. 2.2.3, but here excluding the effects of changes in land cover (using a constant pre-industrial land-cover distribution), provides an independent estimate of the consistency of $S_{\mathrm{LAND}}$ with our understanding of the functioning of the terrestrial vegetation in response to $\mathrm{CO}_{2}$ and climate variability (Table 7). As described in Sect. 2.2.3, the DGVM runs that exclude the effects of changes in land cover include all climate variability and $\mathrm{CO}_{2}$ effects over land but do not include reductions in $\mathrm{CO}_{2}$ sink capacity associated with human activity directly affecting changes in vegetation cover and management, which by design is allocated to $E_{\mathrm{LUC}}$. This effect has been estimated to have led to a reduction in the terrestrial sink by $0.5 \mathrm{GtC} \mathrm{yr}^{-1}$ since 1750 (Gitz and Ciais, 2003). The models in this configuration estimate the mean and variability of $S_{\text {LAND }}$ based on atmospheric $\mathrm{CO}_{2}$ and climate, and thus both terms can be compared to the budget residual.

The multi-DGVM mean of $2.5 \pm 1.0 \mathrm{GtC} \mathrm{yr}^{-1}$ for the period 2004-2013 agrees well with the value computed from the budget residual (Table 7). The standard deviation of the annual $\mathrm{CO}_{2}$ sink across the nine DGVMs ranges from \pm 0.4 to $\pm 1.4 \mathrm{GtC} \mathrm{yr}^{-1}$, with a mean standard deviation of $\pm 0.9 \mathrm{GtC} \mathrm{yr}^{-1}$ for the period 1959 to 2013 . The model mean, 
over different decades, correlates with the budget residual with $r=0.71$, compared to correlations of $r=0.46$ to $r=0.70$ (median of 0.61 ) between individual models. The standard deviation is similar to that of the five model ensembles presented in Le Quéré et al. (2009), but the correlation is improved compared to $r=0.54$ obtained in the earlier study. The DGVM results suggest that the sum of our knowledge on annual $\mathrm{CO}_{2}$ emissions and their partitioning is plausible (see Discussion), and provide insight into the underlying processes and regional breakdown. However as the standard deviation across the DGVMs (of $\pm 0.9 \mathrm{GtC} \mathrm{yr}^{-1}$ ) is of the same magnitude as the combined uncertainty due to the other components ( $E_{\mathrm{FF}}, E_{\mathrm{LUC}}, G_{\mathrm{ATM}}, S_{\mathrm{OCEAN}}$; Table 7 ), the DGVMs do not provide further reduction of uncertainty on the terrestrial $\mathrm{CO}_{2}$ sink compared to the residual of the budget (Eq. 8). Yet, DGVM results are largely independent of the residual of the budget, and it is worth noting that the residual method and ensemble mean DGVM results are consistent within their respective uncertainties. We assess a medium confidence level to the annual land $\mathrm{CO}_{2}$ sink and its uncertainty because the estimates from the residual budget and averaged DGVMs match well within their respective uncertainties, and the estimates based on the residual budget are primarily dependent on $E_{\mathrm{FF}}$ and $G_{\mathrm{ATM}}$, both of which are well constrained.

\subsection{The atmospheric perspective}

The worldwide network of atmospheric measurements can be used with atmospheric inversion methods to constrain the location of the combined total surface $\mathrm{CO}_{2}$ fluxes from all sources, including fossil and LUC emissions and land and ocean $\mathrm{CO}_{2}$ fluxes. As the geographical distribution of fossil fuel emissions is already known, it can be subtracted from the total surface $\mathrm{CO}_{2}$ flux to provide $\mathrm{CO}_{2}$ fluxes over land and over the ocean. Here we used preliminary atmospheric $\mathrm{CO}_{2}$ data to the end of 2013, and three atmospheric $\mathrm{CO}_{2}$ inversions (Table 6) to infer the total $\mathrm{CO}_{2}$ flux over land regions, and the distribution of the total land and ocean $\mathrm{CO}_{2}$ fluxes for the mid- to high-latitude Northern Hemisphere $\left(30-90^{\circ} \mathrm{N}\right)$, tropics $\left(30^{\circ} \mathrm{S}-30^{\circ} \mathrm{N}\right)$ and mid- to high-latitude region of the Southern Hemisphere $\left(30-90^{\circ} \mathrm{S}\right)$. We focus here on the largest and most consistent sources of information, and use these estimates to comment on the consistency across various data streams and process-based estimates.

\section{Atmospheric inversions}

The three inversion systems used in this release (Chevallier et al., 2005; Peters et al., 2010; Rödenbeck, 2005) are based on the same Bayesian inversion principles that interpret the same, for the most part, observed time series (or subsets thereof), but they use different methodologies that represent some of the many approaches used in the field. This mainly concerns the time resolution of the estimates (i.e. weekly or monthly), spatial breakdown (i.e. grid size), assumed cor- relation structures, and mathematical approach. The details of these approaches are documented extensively in the references provided. Each system had used a different transport model, which was demonstrated to be a driving factor behind differences in atmospheric-based flux estimates, and specifically their global distribution (Stephens et al., 2007). Most inverse models use estimates for the ocean and land biosphere, which can be very similar to those described in Sects. 2.4.1 and 2.5.1 to assign prior fluxes. They do not estimate $E_{\mathrm{FF}}$ separately but assign $E_{\mathrm{FF}}$ using similar data sources to those used described in Sects. 2.1.1 and 2.2.2. Finally atmospheric inversions include $\mathrm{CO}_{2}$ fluxes from rivers (which need to be taken into account to allow comparison to other sources) and chemical oxidation of reactive carboncontaining gases (which are neglected here). These inverse estimates are not truly independent of the other estimates presented here as the atmospheric observations include a set of observations used to estimate the global atmospheric growth rate (Sect. 2.3). However they provide new information on the regional distribution of fluxes.

In this first application of inverse methods to the carbon budget we focus the analysis on two known strengths of the inverse approach: the derivation of the year-toyear changes in total land $\left(E_{\mathrm{LUC}}+S_{\mathrm{LAND}}\right)$ fluxes consistent with the whole network of atmospheric observations, and the spatial breakdown of land and ocean fluxes $\left(E_{\mathrm{LUC}}+S_{\mathrm{LAND}}+S_{\text {OCEAN }}\right)$ across large regions of the global. The total land flux correlates well with those estimated from the budget residual (Eq. 1) with corrections for the annual time series ranging from $r=0.84$ to 0.93 , and with the DGVM multi-model mean with correlations for the annual time series ranging from $r=0.71$ to 0.84 ( $r=0.37$ to 0.82 for individual DGVMs and inversions). The spatial breakdown is discussed in Sect. 3.1.3.

\subsection{Processes not included in the global carbon budget \\ 2.7.1 Contribution of anthropogenic $\mathrm{CO}$ and $\mathrm{CH}_{4}$ to the global carbon budget}

Anthropogenic emissions of $\mathrm{CO}$ and $\mathrm{CH}_{4}$ to the atmosphere are eventually oxidised to $\mathrm{CO}_{2}$ and are thus part of the global carbon budget. These contributions are omitted in Eq. (1), but an attempt is made in this section to estimate their magnitude and identify the sources of uncertainty. Anthropogenic CO emissions are from incomplete fossil fuel and biofuel burning and deforestation fires. The main anthropogenic emissions of fossil $\mathrm{CH}_{4}$ that matter for the global carbon budget are the fugitive emissions of coal, oil, and gas upstream sectors (see below). These emissions of $\mathrm{CO}$ and $\mathrm{CH}_{4}$ contribute a net addition of fossil carbon to the atmosphere.

In our estimate of $E_{\mathrm{FF}}$ we assumed (Sect. 2.1.1) that all the fuel burned is emitted as $\mathrm{CO}_{2}$; thus $\mathrm{CO}$ anthropogenic emissions and their atmospheric oxidation into $\mathrm{CO}_{2}$ within a few months are already counted implicitly in $E_{\mathrm{FF}}$ and should 
not be counted twice (same for $E_{\mathrm{LUC}}$ and anthropogenic $\mathrm{CO}$ emissions by deforestation fires). Anthropogenic emissions of fossil $\mathrm{CH}_{4}$ are not included in $E_{\mathrm{FF}}$, because these fugitive emissions are not included in the fuel inventories. Yet they contribute to the annual $\mathrm{CO}_{2}$ growth rate after $\mathrm{CH}_{4}$ gets oxidised into $\mathrm{CO}_{2}$. Anthropogenic emissions of fossil $\mathrm{CH}_{4}$ represent $15 \%$ of total $\mathrm{CH}_{4}$ emissions (Kirschke et al., 2013), which is $0.061 \mathrm{GtC} \mathrm{yr}^{-1}$ for the past decade. Assuming steady state, these emissions are all converted to $\mathrm{CO}_{2}$ by $\mathrm{OH}$ oxidation, thus explaining $0.06 \mathrm{GtC} \mathrm{yr}^{-1}$ of the global $\mathrm{CO}_{2}$ growth rate in the past decade.

Other anthropogenic changes in the sources of $\mathrm{CO}$ and $\mathrm{CH}_{4}$ from wildfires, biomass, wetlands, ruminants, or permafrost changes are similarly assumed to have a small effect on the $\mathrm{CO}_{2}$ growth rate.

\subsubsection{Anthropogenic carbon fluxes in the land-to-ocean continuum}

The approach used to determine the global carbon budget considers only anthropogenic $\mathrm{CO}_{2}$ emissions and their partitioning among the atmosphere, ocean, and land. In this analysis, the land and ocean reservoirs that take up anthropogenic $\mathrm{CO}_{2}$ from the atmosphere are conceived as independent carbon storage repositories. This approach thus omits that carbon is continuously displaced along the land-ocean aquatic continuum (LOAC) comprising freshwaters, estuaries, and coastal areas (Bauer et al., 2013; Regnier et al., 2013). A significant fraction of this lateral carbon flux is entirely "natural" and is thus a steady-state component of the pre-industrial carbon cycle that can be ignored in the current analysis. The remaining fraction is anthropogenic carbon entrained into the lateral transport loop of the LOAC, a perturbation that is relevant for the global carbon budget presented here.

The results of the analysis of Regnier et al. (2013) can be summarised in three points of relevance to the anthropogenic $\mathrm{CO}_{2}$ budget. First, the anthropogenic carbon input from land to hydrosphere, $F_{\mathrm{LH}}$, estimated at $1 \pm 0.5 \mathrm{PgC}$ is significant compared to the other terms of Eq. (1) (Table 8), and implies that only a portion of the anthropogenic $\mathrm{CO}_{2}$ taken up by land ecosystems remains sequestered in soil and biomass pools. Second, some of the exported anthropogenic carbon is stored in the $\mathrm{LOAC}\left(\Delta C_{\mathrm{LOAC}}, 0.55 \pm 0.3 \mathrm{GtC} \mathrm{yr}^{-1}\right)$ and some is released back to the atmosphere as $\mathrm{CO}_{2}\left(E_{\mathrm{LOAC}}\right.$, $0.35 \pm 0.2 \mathrm{GtC} \mathrm{yr}^{-1}$ ), the magnitude of these fluxes resulting from the combined effects of freshwaters, estuaries, and coastal seas. Third, a small fraction of anthropogenic carbon displaced by the LOAC is transferred to the open ocean, where it accumulates $\left(F_{\mathrm{HO}}, 0.1 \pm>0.05 \mathrm{GtC} \mathrm{yr}^{-1}\right)$. The anthropogenic perturbation of the carbon fluxes from land to ocean does not contradict the method used in Sect. 2.5 to define the ocean sink and residual land sink. However, it does point to the need to account for the fate of anthropogenic carbon once it is removed from the atmosphere by land ecosystems (summarised in Fig. 2). In theory, direct estimates of changes of the ocean inorganic carbon inventory over time would see the land flux of anthropogenic carbon and would thus have a bias relative to air-sea flux estimates and tracerbased reconstructions. However, currently the value is small enough to be not noticeable relative to the errors in the individual techniques.

More importantly the residual land sink calculated in a budget which accounts for the LOAC $\left(S_{\text {LAND+LOAC }}=\right.$ $3.25 \pm 0.9 \mathrm{GtC} \mathrm{yr}^{-1}$ ) is larger than the residual land sink $\left(S_{\text {LAND }}\right)$ value of $2.9 \pm 0.85 \mathrm{GtC} \mathrm{yr}^{-1}$ (2004-2013) calculated according to Eq. (8). This is because this flux is partially offset by the net source of $\mathrm{CO}_{2}$ to the atmosphere of $0.35 \pm 0.3 \mathrm{GtC} \mathrm{yr}^{-1}$ from rivers, estuaries, and coastal seas $\left(E_{\mathrm{LOAC}}\right)$ :

$$
\begin{aligned}
S_{\mathrm{LAND}+\mathrm{LOAC}} & =E_{\mathrm{FF}}+E_{\mathrm{LUC}}-\left(G_{\mathrm{ATM}}+S_{\mathrm{OCEAN}}\right) \\
& +E_{\mathrm{LOAC}} .
\end{aligned}
$$

In addition, because a fraction of anthropogenic $\mathrm{CO}_{2}$ taken up by land ecosystems is exported to the LOAC $\left(F_{\mathrm{LH}}\right)$, the annual terrestrial ecosystems carbon storage change comprising the land vegetation, litter, and soil $\left(\Delta C_{\mathrm{TE}}\right.$, $1.35 \mathrm{GtC} \mathrm{yr}^{-1}$ ) is notably smaller than what would be calculated in a traditional budget that ignores the LOAC. In this case, the carbon storage change for the period 2004-2013

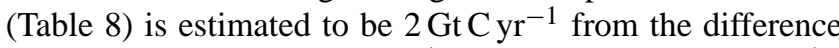
between $S_{\mathrm{LAND}}\left(2.9 \mathrm{GtC} \mathrm{yr}^{-1}\right)$ and $E_{\mathrm{LUC}}\left(0.9 \mathrm{GtC} \mathrm{yr}^{-1}\right)$. With the LOAC included, we now have

$\Delta C_{\mathrm{TE}}=S_{\mathrm{LAND}+\mathrm{LOAC}}-E_{\mathrm{LUC}}-F_{\mathrm{LH}}$.

A significant fraction of the anthropogenic carbon displaced from land ecosystems to LOAC is stored in freshwater and coastal sediments $\left(\Delta C_{\mathrm{LOAC}}\right)$ and, to a lesser extent, in the open ocean $\left(F_{\mathrm{HO}}\right)$, while the rest is re-emitted to the atmosphere by freshwaters $\left(E_{\mathrm{LOAC}}\right)$. The annual ocean carbon storage change with LOAC included $\left(\triangle C_{\text {OCEAN }}\right)$ is therefore equal to $\Delta C_{\text {OCEAN }}=S_{\text {OCEAN }}+F_{\mathrm{HO}}$.

All estimates of LOAC are given with low confidence, because they originate from a single source. The carbon budget presented here implicitly incorporates the fluxes from

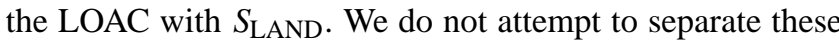
fluxes, because the uncertainties in either estimate are too large and there is insufficient information available to estimate the LOAC fluxes on an annual basis.

\section{Results}

\subsection{Global carbon budget averaged over decades and its variability}

The global carbon budget averaged over the last decade (2004-2013) is shown in Fig. 2. For this time period, $91 \%$ of the total emissions $\left(E_{\mathrm{FF}}+E_{\mathrm{LUC}}\right)$ were caused by fossil fuel combustion and cement production, and $9 \%$ by landuse change. The total emissions were partitioned among the 


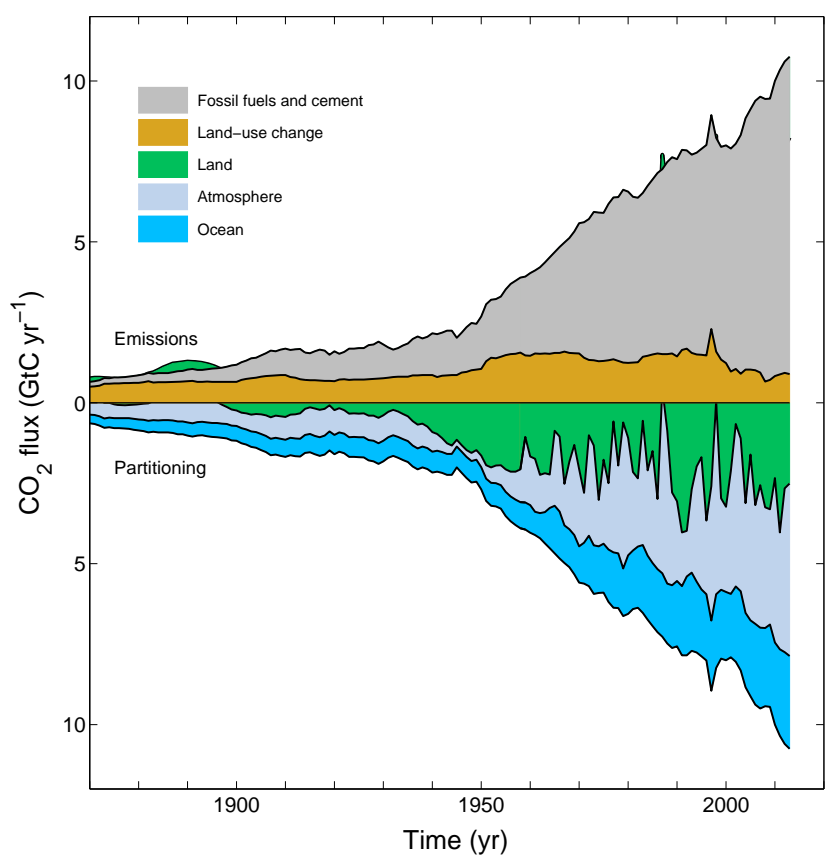

Figure 3. Combined components of the global carbon budget illustrated in Fig. 2 as a function of time for emissions from fossil fuel combustion and cement production ( $E_{\mathrm{FF}}$; grey) and emissions from land-use change ( $E_{\mathrm{LUC}} ;$ brown), as well as their partitioning among the atmosphere $\left(G_{\mathrm{ATM}}\right.$; light blue), land $\left(S_{\mathrm{LAND}}\right.$; green $)$, and oceans ( $S_{\text {OCEAN }}$; dark blue). All time series are in $\mathrm{GtC} \mathrm{yr}^{-1}$. $G_{\mathrm{ATM}}$ and $S_{\mathrm{OCEAN}}$ (and by construction also $S_{\mathrm{LAND}}$ ) prior to 1959 are based on different methods. The primary data sources for fossil fuel and cement emissions are from Boden et al. (2013), with uncertainty of about $\pm 5 \%( \pm 1 \sigma)$; land-use-change emissions are from Houghton et al. (2012) with uncertainties of about $\pm 30 \%$; the atmospheric growth rate prior to 1959 is from Joos and Spahni (2008) with uncertainties of about $\pm 1-1.5 \mathrm{GtC} \mathrm{decade}^{-1}$ or $\pm 0.1-0.15 \mathrm{GtC} \mathrm{yr}^{-1}$ (Bruno and Joos, 1997), and from Dlugokencky and Tans (2014) from 1959 with uncertainties of about $\pm 0.2 \mathrm{GtC} \mathrm{yr}^{-1}$; the ocean sink prior to 1959 is from Khatiwala et al. (2013) with uncertainty of about $\pm 30 \%$, and from this study from 1959 with uncertainties of about $\pm 0.5 \mathrm{GtC} \mathrm{yr}^{-1}$; and the residual land sink is obtained by difference (Eq. 8), resulting in uncertainties of about $\pm 50 \%$ prior to 1959 and $\pm 0.8 \mathrm{GtC} \mathrm{yr}^{-1}$ after that. See the text for more details of each component and their uncertainties.

atmosphere (44\%), ocean (26\%), and land (29\%). All components except land-use-change emissions have grown since 1959 (Figs. 3 and 4), with important interannual variability in the atmospheric growth rate and in the land $\mathrm{CO}_{2} \operatorname{sink}$ (Fig. 4), as well as some decadal variability in all terms (Table 8).

\subsection{1 $\mathrm{CO}_{2}$ emissions}

Global $\mathrm{CO}_{2}$ emissions from fossil fuel combustion and cement production have increased every decade from an average of $3.1 \pm 0.2 \mathrm{GtC} \mathrm{yr}^{-1}$ in the 1960 s to an average of $8.9 \pm 0.4 \mathrm{GtC} \mathrm{yr}^{-1}$ during 2004-2013 (Table 8 and Fig. 5).
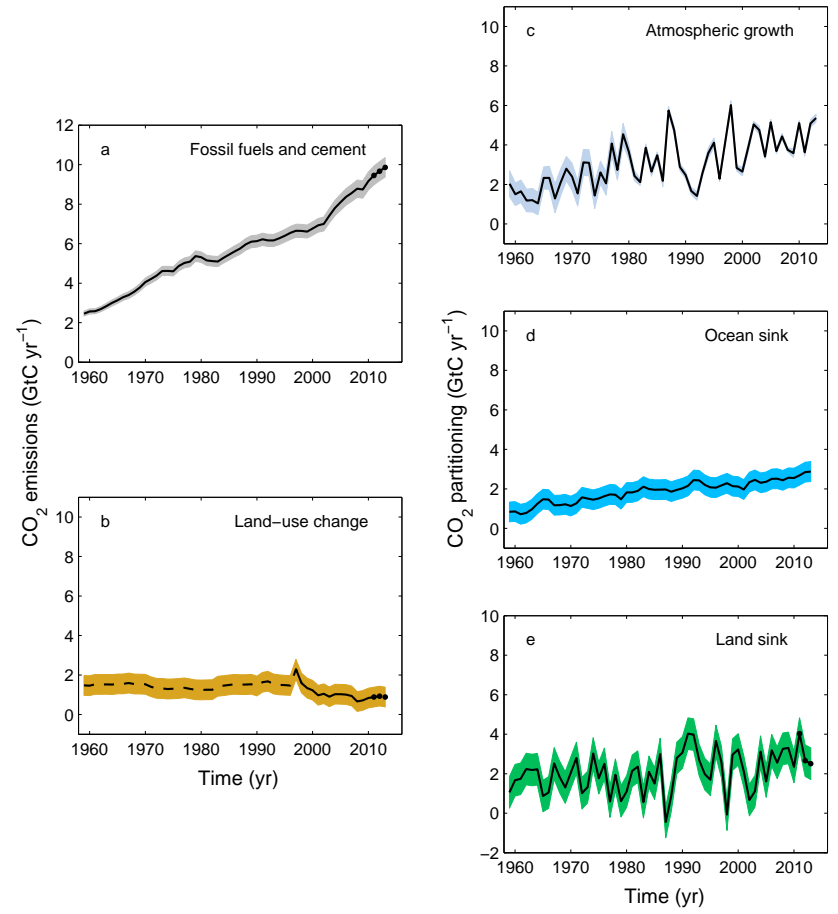

Figure 4. Components of the global carbon budget and their uncertainties as a function of time, presented individually for (a) emissions from fossil fuel combustion and cement production $\left(E_{\mathrm{FF}}\right)$, (b) emissions from land-use change $\left(E_{\mathrm{LUC}}\right),(\mathbf{c})$ atmospheric $\mathrm{CO}_{2}$ growth rate $\left(G_{\mathrm{ATM}}\right)$, (d) the ocean $\mathrm{CO}_{2} \operatorname{sink}\left(S_{\mathrm{OCEAN}}\right.$; positive indicates a flux from the atmosphere to the ocean), and (e) the land $\mathrm{CO}_{2}$ sink $\left(S_{\mathrm{LAND}}\right.$; positive indicates a flux from the atmosphere

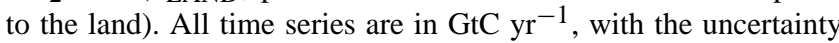
bounds representing $\pm 1 \sigma$ in shaded colour. Data sources are as in Fig. 2. The black dots in panels (a), (b), and (e) show values for 2011, 2012, and 2013 that originate from a different data set to the remainder of the data, as explained in the text.

The growth rate in these emissions decreased between the $1960 \mathrm{~s}$ and the $1990 \mathrm{~s}$, from $4.5 \% \mathrm{yr}^{-1}$ in the 1960s (1960$1969)$, to $2.9 \% \mathrm{yr}^{-1}$ in the $1970 \mathrm{~s}$ (1970-1979), to $1.9 \% \mathrm{yr}^{-1}$ in the $1980 \mathrm{~s}$ (1980-1989), and finally to $1.0 \% \mathrm{yr}^{-1}$ in the 1990s (1990-1999), before it began increasing again in the $2000 \mathrm{~s}$ at an average growth rate of $3.3 \% \mathrm{yr}^{-1}$, decreasing slightly thereafter to $2.5 \% \mathrm{yr}^{-1}$ for the last decade (20042013). In contrast, $\mathrm{CO}_{2}$ emissions from LUC have remained constant, in our analysis at around $1.5 \pm 0.5 \mathrm{GtC} \mathrm{yr}^{-1}$ between 1960 and 1999 and $0.9 \pm 0.5 \mathrm{GtC} \mathrm{yr}^{-1}$ during 20042013. The $E_{\mathrm{LUC}}$ estimates from the bookkeeping method and the DGVM models are consistent within their respective uncertainties (Table 7 and Fig. 6). However, whereas the decrease in emissions from LUC between the 1990s and 2000s is also present in the DGVMs (Fig. 6), it was not found in the study of tropical deforestation of Achard et al. (2014), where the fluxes in the 1990s were similar to those of the 2000s and outside our uncertainty range. 

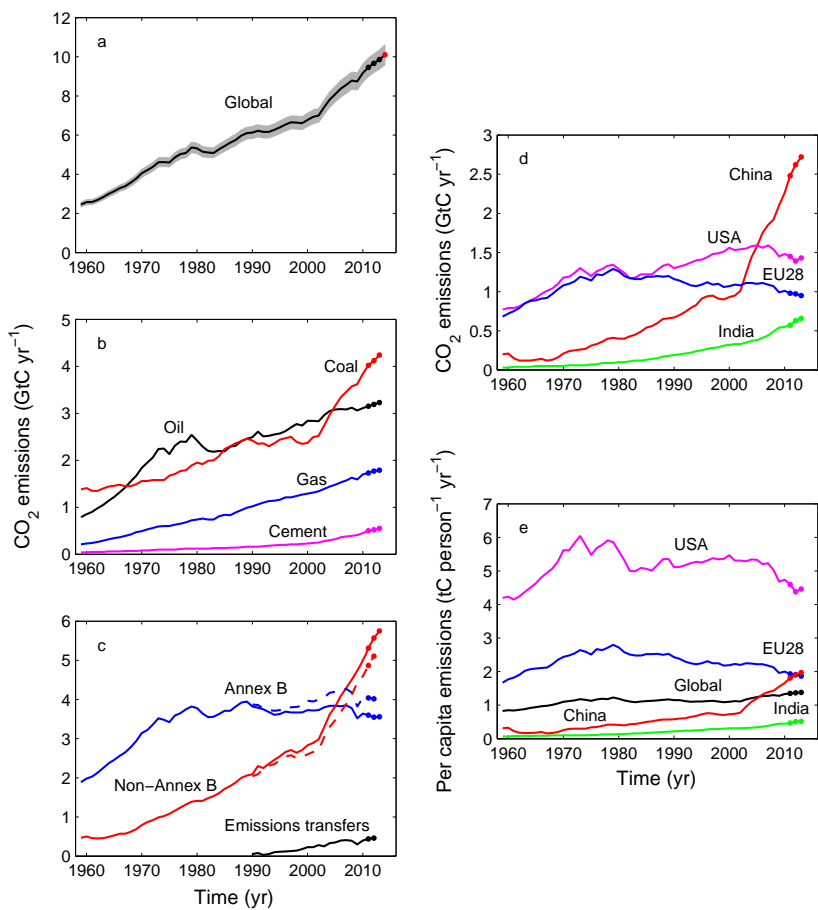

Figure 5. $\mathrm{CO}_{2}$ emissions from fossil fuel combustion and cement production for (a) the globe, including an uncertainty of $\pm 5 \%$ (grey shading), the emissions extrapolated using BP energy statistics (black dots) and the emissions projection for year 2014 based on GDP projection (red dot); (b) global emissions by fuel type, including coal (red), oil (black), gas (blue), and cement (purple) and excluding gas flaring, which is small (0.6\% in 2013); (c) territorial (full line) and consumption (dashed line) emissions for the countries listed in Annex B of the Kyoto Protocol (blue lines; mostly advanced economies with emissions limitations) versus non-Annex B countries (red lines) - also shown are the emission transfers from non-Annex B to Annex B countries (black line); (d) territorial $\mathrm{CO}_{2}$ emissions for the top three country emitters (USA - purple; China - red; India - green) and for the European Union (EU; blue for the 28 member states of the EU in 2012); and (e) per capita emissions for the top three country emitters and the EU (all colours as in panel d) and the world (black). In (b) to (e), the dots show the data that were extrapolated from BP energy statistics for 2011, 2012, and 2013. All time series are in $\mathrm{GtC} \mathrm{yr}^{-1}$ except the per capita emissions (panel e), which are in tonnes of carbon per person per year $\left(\mathrm{tC}\right.$ person ${ }^{-1} \mathrm{yr}^{-1}$ ). All territorial emissions are primarily from Boden et al. (2013) as detailed in the text; consumption-based emissions are updated from Peters et al. (2011a).

\subsubsection{Partitioning}

The growth rate in atmospheric $\mathrm{CO}_{2}$ increased from $1.7 \pm 0.1 \mathrm{GtC} \mathrm{yr}^{-1}$ in the 1960 s to $4.3 \pm 0.1 \mathrm{GtC} \mathrm{yr}^{-1}$ during 2004-2013 with important decadal variations (Table 8). Both ocean and land $\mathrm{CO}_{2}$ sinks increased roughly in line with the atmospheric increase, but with significant decadal variability on land (Table 8). The ocean $\mathrm{CO}_{2}$ sink increased from $1.1 \pm 0.5 \mathrm{GtC} \mathrm{yr}^{-1}$ in the $1960 \mathrm{~s}$ to $2.6 \pm 0.5 \mathrm{GtC} \mathrm{yr}^{-1}$
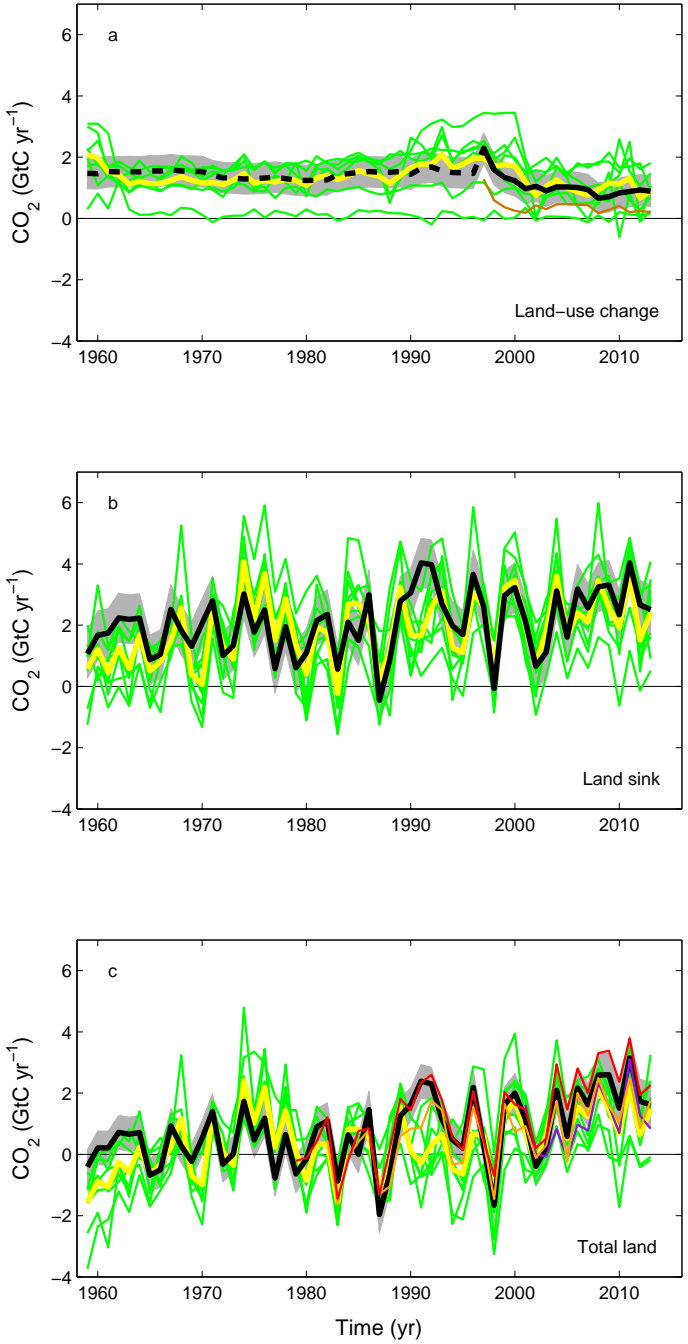

Figure 6. Comparison of the atmosphere-land $\mathrm{CO}_{2}$ flux showing budget values of $E_{\mathrm{LUC}}$ (black line). (a) $\mathrm{CO}_{2}$ emissions from landuse change showing individual DGVM model results (green) and the multi-model mean (yellow line), and fire-based results (brown); LUC data prior to 1997 (dashed black line) highlights the start of satellite data from that year. (b) Land $\mathrm{CO}_{2}$ sink $\left(S_{\text {LAND }}\right)$ showing individual DGVM model results (green) and multi-model mean (yellow line). (c) Total land $\mathrm{CO}_{2}$ fluxes (sum of $\mathbf{a}+\mathbf{b}$ ) from DGVM model results (green) and the multi-model mean (yellow line), atmospheric inversions (MACC, v13.1 (Chevallier et al., 2005) in red; Rödenbeck et al. (2003) in orange; Peters et al. (2010) in purple; see Table 6), and the carbon balance from Eq. (1) (black). In (c) the inversions were corrected for the pre-industrial land sink of $\mathrm{CO}_{2}$ from river input by adding a sink of $0.45 \mathrm{GtC} \mathrm{yr}^{-1}$ (Jacobson et al., 2007). This correction does not take into account the anthropogenic contribution to river fluxes (see Sect. 2.7.2).

during 2004-2013, with interannual variations of the order of a few tenths of $\mathrm{GtC} \mathrm{yr}^{-1}$ generally showing an increased ocean sink during El Niño events (i.e. 1982-1983, 19911993, 1997-1998) (Fig. 7; Rödenbeck et al., 2014). Although there is some coherence between the ocean models and data 
products and among data products, their mutual correlation is weak and highlights disagreement on the exact amplitude of the interannual variability, as well as on the relative importance of the trend versus the variability (Sect. 2.4.3 and Fig. 7). Most estimates produce a mean $\mathrm{CO}_{2}$ sink for the 1990s that is below the mean assessed by the IPCC from indirect (but arguably more reliable) observations (Denman et al., 2007; Sect. 2.4.1). This could reflect issues with the vertical diffusion in ocean models, although as the data products also support a lower mean $\mathrm{CO}_{2}$ sink, this discrepancy suggests we may need to reassess estimates of the mean ocean carbon sinks.

The land $\mathrm{CO}_{2}$ sink increased from $1.8 \pm 0.7 \mathrm{GtC} \mathrm{yr}^{-1}$ in the 1960 s to $2.9 \pm 0.8 \mathrm{GtC} \mathrm{yr}^{-1}$ during 2004-2013, with important interannual variations of up to $2 \mathrm{GtC} \mathrm{yr}^{-1}$ generally showing a decreased land sink during El Niño events, overcompensating for the increased in ocean sink and accounting for the enhanced atmospheric growth rate during El Niño events (Poulter et al., 2014). The high-uptake anomaly around year 1991 is thought to be caused by the effect of the volcanic eruption of Mount Pinatubo on climate (Achard et al., 2014; Fig. 6c) and is not generally reproduced by the DGVMs but assigned to $S_{\text {LAND }}$ by the two inverse systems that include this period (Fig. 6). The larger land $\mathrm{CO}_{2}$ sink during 2004-2013 compared to the 1960s is reproduced by all the DGVMs in response to combined atmospheric $\mathrm{CO}_{2}$ increase, climate, and variability (average change of $1.4 \mathrm{GtC} \mathrm{yr}^{-1}$; eight models ranging between 0.8 and $2.3 \mathrm{GtC} \mathrm{yr}^{-1}$ with one model at $0.1 \mathrm{GtC} \mathrm{yr}^{-1}$ ), consistent with the budget residual and reflecting a common knowledge of the processes (Table 7). The decadal change is also consistent with the results from the atmospheric inversions, which estimate a trend of 0.84 and $0.62 \mathrm{GtC} \mathrm{yr}^{-1}$ per decade for the inversions of Chevallier et al. (2005) and Rödenbeck et al. (2003), respectively.

The total $\mathrm{CO}_{2}$ fluxes on land $\left(E_{\mathrm{LUC}}+S_{\mathrm{LAND}}\right)$ constrained by the atmospheric inversions show in general very good agreement with the global budget estimate, as expected given the strong constrains of $G_{\mathrm{ATM}}$ and the small relative uncertainty typically assumed on $S_{\mathrm{OCEAN}}$ and $E_{\mathrm{FF}}$ by inversions. The total sink of similar magnitude for the decadal average, with estimates for 2004-2013 from the inversions of $1.7,2.0$, and $3.1 \mathrm{GtC} \mathrm{yr}^{-1}$ compared to $2.0 \pm-0.7 \mathrm{GtC} \mathrm{yr}^{-1}$ for the budget residual (Table 7). The inversions' total land sink would be $1.2,1.5$, and $2.6 \mathrm{GtC} \mathrm{yr}^{-1}$ when including a mean river flux correction of $0.45 \mathrm{GtC} \mathrm{yr}^{-1}$, though the exact correction would be smaller when taking into account the anthropogenic contribution to river fluxes (Sect. 2.7.2). The interannual variability of the inversions also matched the residual-based $S_{\text {LAND }}$ closely (Fig. 6). The multi-model mean from the DGVM ensemble that preformed the LUC simulations also compares well with the estimate from the residual budget and atmospheric inversions, with a decadal mean of $1.4 \pm-1.0 \mathrm{GtC} \mathrm{yr}^{-1}$ (Table 7; 2004-2013), al-

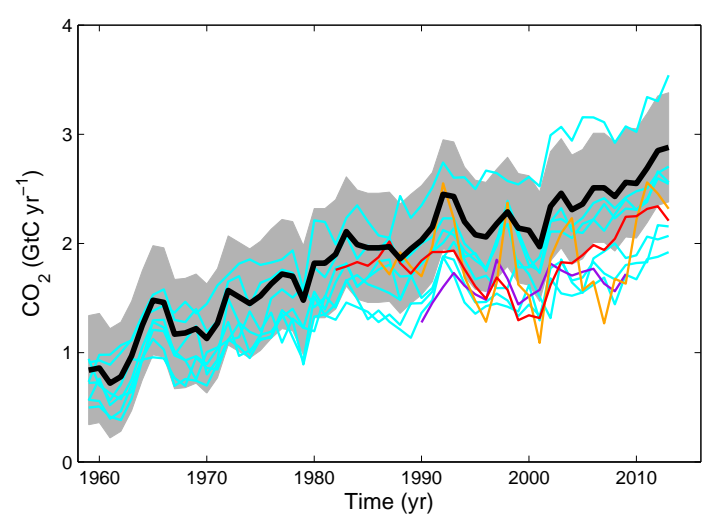

Figure 7. Comparison of the atmosphere-ocean $\mathrm{CO}_{2}$ flux shows the budget values of $S_{\text {OCEAN }}$ (black line), individual ocean models before normalisation (blue lines), and the three ocean databased products (Rödenbeck et al. (2014) in orange, Landschützer et al. (2014) in red, and Park et al. (2010) in purple; see Table 6). All data-based products were corrected for the pre-industrial ocean source of $\mathrm{CO}_{2}$ from river input to the ocean, which is not present in the models, by adding a sink of $0.45 \mathrm{GtC} \mathrm{yr}^{-1}$ (Jacobson et al., 2007 ) in order to make them comparable to $S_{\text {OCEAN. This correc- }}$ tion does not take into account the anthropogenic contribution to river fluxes (see Sect. 2.7.2).

though individual models differ by several gigatonnes of carbon for some years (Fig. 6).

\subsubsection{Distribution}

The total surface $\mathrm{CO}_{2}$ fluxes on land and ocean including LUC $\left(E_{\mathrm{LUC}}+S_{\mathrm{LAND}}+S_{\text {OCEAN }}\right)$ estimated from process models and atmospheric inversions can provide information on the regional distribution of those fluxes by latitude band (Fig. 8). The global mean $\mathrm{CO}_{2}$ fluxes from process models for 2004-2013 is $2.8 \mathrm{GtC} \mathrm{yr}^{-1}$, an underestimate compared to the fluxes of $4.5 \mathrm{GtC} \mathrm{yr}^{-1}$ inferred from the remainder of the carbon budget $\left(E_{\mathrm{FF}}-G_{\mathrm{ATM}}\right.$ in Eq. 1 ; Table 8$)$. In contrast, the total $\mathrm{CO}_{2}$ fluxes from the three inversions range between 4.1 and $4.7 \mathrm{GtC} \mathrm{yr}^{-1}$, consistent with the carbon budget as expected from the constraints on the inversions.

In the south (south of $30^{\circ} \mathrm{S}$ ), the atmospheric inversions and combined models all suggest a $\mathrm{CO}_{2}$ sink for 2004-2013 of between 1.3 and $1.6 \mathrm{GtC} \mathrm{yr}^{-1}$ (Fig. 8), although the details of the interannual variability are not fully consistent across methods. The interannual variability in the south is low because of the dominance of ocean area with low variability compared to land areas. In the tropics $\left(30^{\circ} \mathrm{S}-30^{\circ} \mathrm{N}\right)$, both the atmospheric inversions and combined models suggest the carbon balance in this region is close to neutral over the past decade, with fluxes for 2004-2013 ranging between -0.3 and $+0.4 \mathrm{GtC} \mathrm{yr}^{-1}$. This region also shows the largest variability, both on interannual and decadal timescales.

In the north (north of $30^{\circ} \mathrm{N}$ ), the inversions and combined models disagree on the magnitude of the $\mathrm{CO}_{2}$ sink, 

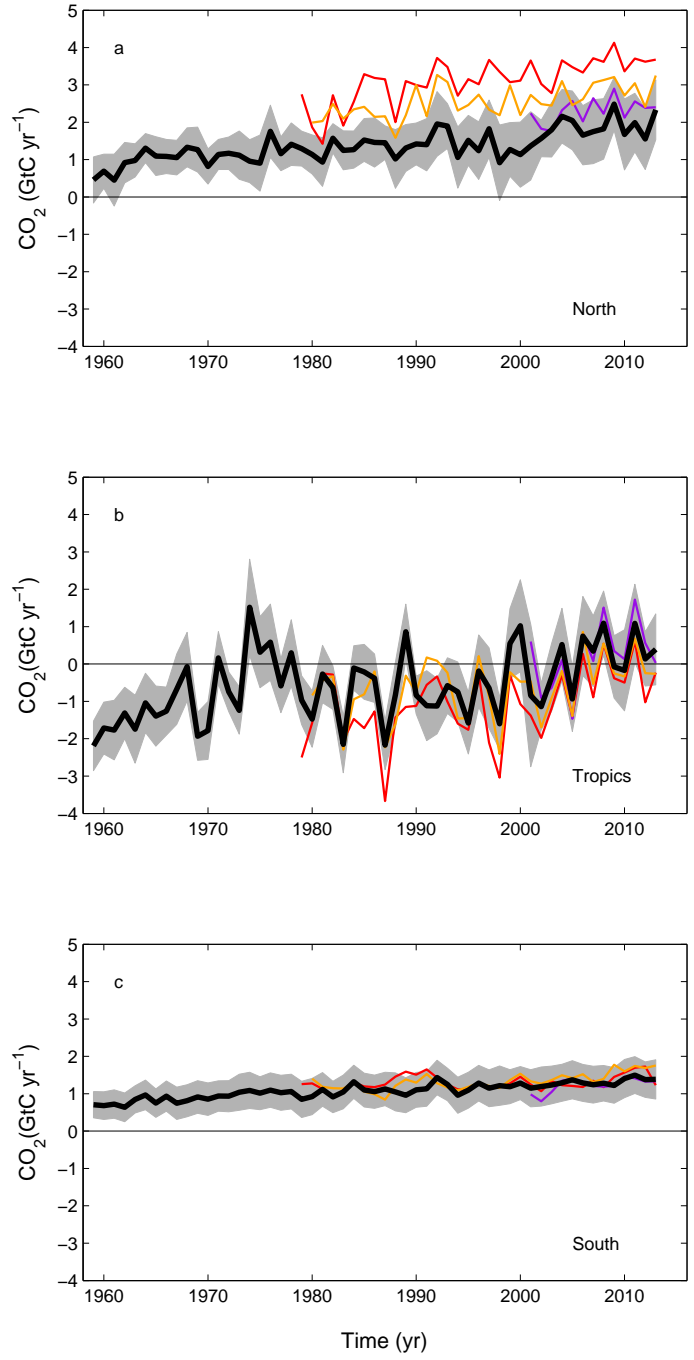

Figure 8. Surface $\mathrm{CO}_{2}$ flux by latitude bands for the north (top panel, north of $30^{\circ} \mathrm{N}$ ), tropics (middle panel, $30^{\circ} \mathrm{S}-30^{\circ} \mathrm{N}$ ), and south (south of $30^{\circ} \mathrm{S}$ ). Estimates from the combination of the multimodel means for the land and oceans are shown (black) with $\pm 1 \sigma$ of the model ensemble (in grey). Results from the three atmospheric inversions are shown (MACC, v13.1 (Chevallier et al., 2005) in red; Rödenbeck et al. (2003) in orange; Peters et al. (2010) in purple; Table 6).

with the ensemble mean of the process models suggesting a smaller total Northern Hemisphere sink for 2004-2013 of $2.0 \pm 0.8 \mathrm{GtC} \mathrm{yr}^{-1}$, while the inversions estimate a sink of between 2.4 and $3.6 \mathrm{GtC} \mathrm{yr}^{-1}$, though some agreement exists in the interannual variability. The mean difference can only partly be explained by the influence of river fluxes, as this flux in the Northern Hemisphere would be less than $0.45 \mathrm{GtC} \mathrm{yr}^{-1}$, particularly when the anthropogenic contribution to river fluxes are accounted for. This analysis thus suggests that the global underestimate of process models originates in the north.

\subsection{Global carbon budget for year 2013 and emissions projection for 2014}

\subsection{1 $\mathrm{CO}_{2}$ emissions}

Global $\mathrm{CO}_{2}$ emissions from fossil fuel combustion and cement production reached $9.9 \pm 0.5 \mathrm{GtC}$ in 2013 (Fig. 5), $2.3 \%$ (including leap-year correction) higher than the emissions in 2012. This compares to our projection of $2.1 \% \mathrm{yr}^{-1}$ made last year (Le Quéré et al., 2014), based on an estimated GDP growth of $2.9 \% \mathrm{yr}^{-1}$ and improvement in $I_{\mathrm{FF}}$ of $-0.8 \% \mathrm{yr}^{-1}$ (Table 9). The latest estimate of GDP growth for 2013 was $3.3 \% \mathrm{yr}^{-1}$ (IMF, 2014) and hence $I_{\mathrm{FF}}$ improved by $-1.0 \% \mathrm{yr}^{-1}$, very close to our projection. The 2013 emissions were distributed among coal $(43 \%)$, oil $(33 \%)$, gas $(18 \%)$, cement $(5.5 \%)$, and gas flaring $(0.6 \%)$. The first four categories increased by $3.0,1.4,1.4$, and $4.7 \%$, respectively, over the previous year (including leap-year adjustment). Due to lack of data, gas flaring in 2012 and 2013 is assumed equal to 2011 .

Using Eq. (6), we estimate that global fossil fuel $\mathrm{CO}_{2}$ emissions in 2014 will reach $10.1 \pm 0.6 \mathrm{GtC}$ $\left(37.0 \pm 2.2 \mathrm{GtCO}_{2}\right)$, or $2.5 \%$ above 2013 levels (likely range of 1.3-3.5\%; see Friedlingstein et al., 2014), and that emissions in 2014 will be $65 \%$ above emissions in 1990. The expected value is computed using the world GDP projection of $3.3 \%$ made by the IMF (2014) and a growth rate for $I_{\mathrm{FF}}$ of $-0.7 \% \mathrm{yr}^{-1}$, which is the average from the previous 10 years. The $I_{\mathrm{FF}}$ is based on GDP in constant PPP (purchasing power parity) from the IEA (2013) up to 2011 (IEA/OECD, 2013) and extended using the IMF growth rates of $2.9 \%$ in 2012 and $3.3 \%$ in 2013. The uncertainty range is based on an uncertainty of $0.3 \%$ for GDP growth (the range in IMF estimates of 2014 GDP growth published in January, April, and July 2014 was 3.7, 3.6, and 3.4\%, respectively) and the range in $I_{\mathrm{FF}}$ due to short-term trends of $-0.7 \% \mathrm{yr}^{-1}$ (2009-2013) and medium-term trends of $-1.0 \% \mathrm{yr}^{-1}$ (1994-2013). The combined uncertainty range is therefore $1.2 \%(2.5-0.3-1.0$; low GDP growth, large $I_{\mathrm{FF}}$ improvements $)$ and $2.1 \%(2.5+0.3-0.7$; high GDP growth, small $I_{\mathrm{FF}}$ improvements). Projections made in the previous global carbon budgets compared well to the actual $\mathrm{CO}_{2}$ emissions for that year (Table 9 and Fig. 9) and were useful to capture the current state of the fossil fuel emissions (see also Peters et al., 2013).

In 2013, global $\mathrm{CO}_{2}$ emissions were dominated by emissions from China ( $28 \%$ ), the USA (14\%), the EU (28 member states; $10 \%$ ), and India (7\%) compared to the global total including bunker fuels. These four regions account for $58 \%$ of global emissions. Growth rates for these countries from 2012 to 2013 were $4.2 \%$ (China), $2.9 \%$ (USA), $-1.8 \%$ (EU28), and $5.1 \%$ (India). The countries contributing most to the 2013 change in emissions were China (58\% of the increase), the USA ( $20 \%$ of the increase), India (17\% of the increase), and EU28 (11\% of the decrease). The per 
Table 9. Actual $\mathrm{CO}_{2}$ emissions from fossil fuel combustion and cement production $\left(E_{\mathrm{FF}}\right)$ compared to projections made the previous year based on world GDP (IMF October 2013) and the fossil fuel intensity of GDP $\left(I_{\mathrm{FF}}\right)$ based on subtracting the $\mathrm{CO}_{2}$ and GDP growth rates. The "Actual" values are the latest estimate available, and the "Projected" value for 2013 refers to those estimates presented in this paper. A correction for leap years is applied (Sect. 2.1.3).

\begin{tabular}{|c|c|c|c|c|c|c|c|c|c|c|c|}
\hline & \multicolumn{2}{|c|}{$2009^{a}$} & \multicolumn{2}{|c|}{$2010^{b}$} & \multicolumn{2}{|c|}{$2011^{\mathrm{c}}$} & \multicolumn{2}{|c|}{$2012^{\mathrm{d}}$} & \multicolumn{2}{|c|}{$2013^{\mathrm{e}}$} & \multirow{2}{*}{ 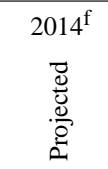 } \\
\hline & $\begin{array}{l}\vec{d} \\
\frac{d}{0} \\
\frac{d}{0}\end{array}$ & 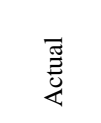 & $\begin{array}{l}\vec{J} \\
\frac{\tilde{J}}{0} \\
\frac{0}{0} \\
0\end{array}$ & 丞 & $\begin{array}{l}\overrightarrow{0} \\
\frac{0}{0} \\
\frac{d}{O} \\
0\end{array}$ & 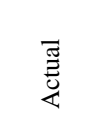 & 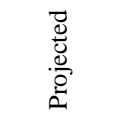 & 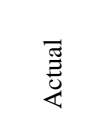 & $\begin{array}{l}\vec{d} \\
\frac{d}{0} \\
\frac{\mathscr{D}}{0} \\
0\end{array}$ & $\begin{array}{l}\bar{\Xi} \\
\stackrel{0}{0}\end{array}$ & \\
\hline$E_{\mathrm{FF}}$ & $-2.8 \%$ & $-0.5 \%$ & $>3 \%$ & $4.9 \%$ & $3.1 \pm 1.5 \%$ & $3.2 \%$ & $\begin{array}{c}2.6 \% \\
(1.9-3.5)\end{array}$ & $2.2 \%$ & $\begin{array}{c}2.1 \\
(1.1-3.1)\end{array}$ & $2.3 \%$ & $\begin{array}{c}2.5 \% \\
(1.3-3.5)\end{array}$ \\
\hline GDP & $-1.1 \%$ & $-0.4 \%$ & $4.8 \%$ & $5.2 \%$ & $4.0 \%$ & $3.9 \%$ & $3.3 \%$ & $3.2 \%$ & $2.9 \%$ & $3.2 \%$ & $3.3 \%$ \\
\hline$I_{\mathrm{FF}}$ & $-1.7 \%$ & $-0.9 \%$ & $>-1.7 \%$ & $-0.3 \%$ & $-0.9 \pm 1.5 \%$ & $-0.7 \%$ & $-0.7 \%$ & $-1.0 \%$ & $-0.8 \%$ & $-0.9 \%$ & $-0.7 \%$ \\
\hline
\end{tabular}

${ }^{\mathrm{a}}$ Le Quéré et al. (2009). ${ }^{\mathrm{b}}$ Friedlingstein et al. (2010). ${ }^{\mathrm{c}}$ Peters et al. (2013). ${ }^{\mathrm{d}}$ Le Quéré et al. (2013). ${ }^{\mathrm{e}}$ Le Quéré et al. (2014). ${ }^{\mathrm{f}}$ Friedlingstein et al. (2014) and this study.
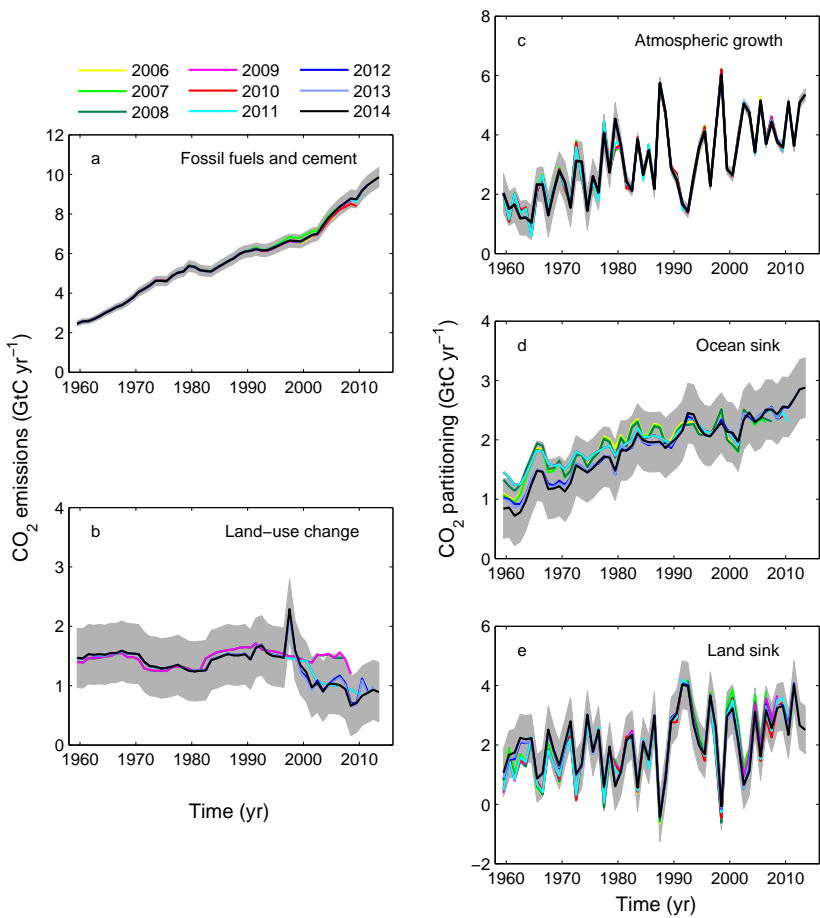

Figure 9. Comparison of global carbon budget components released annually by GCP since 2006. $\mathrm{CO}_{2}$ emissions from both (a) fossil fuel combustion and cement production $\left(E_{\mathrm{FF}}\right)$, and (b) land-use change $\left(E_{\mathrm{LUC}}\right)$, and their partitioning among (c) the atmosphere $\left(G_{\text {ATM }}\right)$, $(\mathbf{d})$ ocean $\left(S_{\text {OCEAN }}\right)$, and (e) land $\left(S_{\text {LAND }}\right)$. See legend for the corresponding years, with the 2006 carbon budget from Raupach et al. (2007), 2007 from Canadell et al. (2007), 2008 released online only, 2009 from Le Quéré et al. (2009), 2010 from Friedlingstein et al. (2010), 2011 from Peters et al. (2012b), 2012 from Le Quéré et al. (2013), and 2013 from Le Quéré et al. (2014) and this year's budget (2014). The budget year generally corresponds to the year when the budget was first released. All values are in $\mathrm{GtC}_{\mathrm{yr}}{ }^{-1}$. capita $\mathrm{CO}_{2}$ emissions in 2013 were $1.4 \mathrm{tC}$ person ${ }^{-1} \mathrm{yr}^{-1}$ for the globe, and were 4.5 (USA), 2.0 (China), 1.9 (EU28) and $0.5 \mathrm{tC}$ person ${ }^{-1} \mathrm{yr}^{-1}$ (India) for the four highest emitting countries (Fig. 5e).

Territorial emissions in Annex B countries have remained stable from 1990 to 2012, while consumption emissions grew at $0.5 \% \mathrm{yr}^{-1}$ (Fig. 5c). In non-Annex B countries, territorial emissions have grown at $4.4 \% \mathrm{yr}^{-1}$, while consumption emissions have grown at $4.1 \% \mathrm{yr}^{-1}$. In $1990,62 \%$ of global territorial emissions were emitted in Annex B countries (34\% in non-Annex B, and $4 \%$ in bunker fuels used for international shipping and aviation), while in 2012 this had reduced to $37 \%$ (58\% in non-Annex $\mathrm{B}$, and $6 \%$ in bunker fuels). In terms of consumption emissions this split was $63 \%$ in 1990 and $43 \%$ in 2012 (33 to $51 \%$ in non-Annex B). The difference between territorial and consumption emissions (the net emission transfer via international trade) from non-Annex B to Annex B countries has increased from $0.05 \mathrm{GtC} \mathrm{yr}^{-1}$ in 1990 to $0.46 \mathrm{GtC} \mathrm{yr}^{-1}$ in 2012 (Fig. 5), with an average annual growth rate of $11 \% \mathrm{yr}^{-1}$. The increase in net emission transfers of $0.41 \mathrm{GtC} \mathrm{yr}^{-1}$ from 1990 to 2012 compares with the emission reduction of $0.27 \mathrm{GtC} \mathrm{yr}^{-1}$ in Annex B countries. These results clearly show a growing net emission transfer via international trade from non-Annex B to Annex B countries. In 2012, the biggest emitters from a consumption perspective were China $(23 \%$ of the global total), the USA (16\%), EU28 (13\%), and India (6\%).

Based on DGVMs only, the global $\mathrm{CO}_{2}$ emissions from land-use-change activities are estimated to be $0.9 \pm 0.6 \mathrm{GtC}$ in 2013, slightly below the 2004-2013 average of $1.0 \pm 0.7 \mathrm{GtC} \mathrm{yr}^{-1}$. However, although the decadal mean generally agreed, the estimated annual variability was not consistent between the LUC emissions estimated based on the combined bookkeeping method and fire-based estimate and the DGVMs, except that they are small relative to the variability from the residual land sink (Fig. 6a). This could be partly due to the design of the DGVM experiments, which use flux differences between simulations with and without 
land-cover change, and thus may overestimate variability due to, for example, fires in forest regions where the contemporary forest cover is smaller than pre-industrial cover used in the runs without land-cover change. The extrapolated landcover input data for 2010-2013 may also explain part of the discrepancy, though it would not account for the larger variability in the DGVMs.

\subsubsection{Partitioning}

The atmospheric $\mathrm{CO}_{2}$ growth rate was $5.4 \pm 0.2 \mathrm{GtC}$ in $2013(2.53 \pm 0.09 \mathrm{ppm}$, Fig. 4; Dlugokencky and Tans, 2014). This is significantly above the 2004-2013 average of $4.3 \pm 0.1 \mathrm{GtC} \mathrm{yr}^{-1}$, though the interannual variability in atmospheric growth rate is large.

The ocean $\mathrm{CO}_{2}$ sink was $2.9 \pm 0.5 \mathrm{GtC} \mathrm{yr}^{-1}$ in 2013 , an

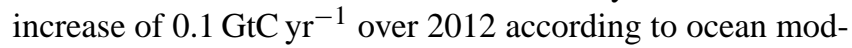
els. Five of the seven ocean models produce an increase in the ocean $\mathrm{CO}_{2}$ sink in 2013 compared to 2012. However the two data products available over that period produce a decrease of

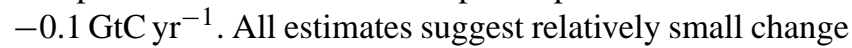
in the ocean $\mathrm{CO}_{2}$ sink, consistent with $\mathrm{El}$ Niño neutral conditions observed in 2013. All estimates suggest an ocean $\mathrm{CO}_{2}$ sink for 2013 that is larger than the 2004-2013 average of $2.6 \pm 0.5 \mathrm{GtC} \mathrm{yr}^{-1}$. The terrestrial $\mathrm{CO}_{2}$ sink calculated as the residual from the carbon budget was $2.5 \pm 0.9 \mathrm{GtC}$ in 2013, just below the $2.7 \pm 0.9 \mathrm{GtC}$ in 2012 and the 2004-2013 average of $2.9 \pm 0.8 \mathrm{GtC} \mathrm{yr}^{-1}$ (Fig. 4), and also consistent with El Niño neutral conditions. The DGVM model mean suggests the same terrestrial $\mathrm{CO}_{2}$ sink in 2013 of $2.4 \pm 1.2 \mathrm{GtC}$ (Table 7), but results cover a range among models.

Cumulative emissions for 1870-2013 were $390 \pm 20 \mathrm{GtC}$ for $E_{\mathrm{FF}}$ and $145 \pm 50 \mathrm{GtC}$ for $E_{\mathrm{LUC}}$ based on the bookkeeping method of Houghton et al. (2012) for 1870-1996 and a combination with fire-based emissions for 1997-2013 as described in Sect. 2.2 (Table 10). The cumulative emissions are rounded to the nearest $5 \mathrm{GtC}$. The total cumulative emissions for 1870-2013 are $535 \pm 55 \mathrm{GtC}$. These emissions were partitioned among the atmosphere $(225 \pm 5 \mathrm{GtC}$ based on atmospheric measurements in ice cores of 288 ppm (Sect. "Global atmospheric $\mathrm{CO}_{2}$ growth rate estimates"; Joos and Spahni, 2008) and recent direct measurements of $395.31 \mathrm{ppm}$ (Dlugokencky and Tans, 2014)), ocean (150 $\pm 20 \mathrm{GtC}$ using Khatiwala et al., 2013, prior to 1959 and Table 8 otherwise), and land ( $155 \pm 60 \mathrm{GtC}$ by the difference).

Cumulative emissions for the early period 1750-1869 were $3 \mathrm{GtC}$ for $E_{\mathrm{FF}}$ and about $45 \mathrm{GtC}$ for $E_{\mathrm{LUC}}$ (rounded to nearest 5), of which $10 \mathrm{GtC}$ was emitted in the period 1850-1870 (Houghton et al., 2012) and 30 GtC was emitted in the period 1750-1850 based on the average of four publications ( $22 \mathrm{GtC}$ by Pongratz et al., 2009; $15 \mathrm{GtC}$ by van Minnen et al., 2009; 64 GtC by Shevliakova et al., 2009; and $24 \mathrm{GtC}$ by Zaehle et al., 2011). The growth in atmospheric $\mathrm{CO}_{2}$ during that time was about $25 \mathrm{GtC}$, and the ocean uptake about $20 \mathrm{GtC}$, implying a land uptake of $5 \mathrm{GtC}$. These numbers have large relative uncertainties but balance within the limits of our understanding.

Cumulative emissions for 1750-2013 based on the sum of the two periods above were $395 \pm 20 \mathrm{GtC}$ for $E_{\mathrm{FF}}$, and $185 \pm 65 \mathrm{GtC}$ for $E_{\mathrm{LUC}}$, for a total of $580 \pm 70 \mathrm{GtC}$, partitioned among the atmosphere $(250 \pm 5 \mathrm{GtC})$, ocean $(170 \pm 20 \mathrm{GtC})$, and land $(160 \pm 70 \mathrm{GtC})$.

Cumulative emissions through to year 2014 can be estimated based on the 2014 projections of $E_{\mathrm{FF}}$ (Sect. 3.2), the largest contributor, and assuming a constant $E_{\mathrm{LUC}}$ of $0.9 \mathrm{GtC}$. For 1870-2014, these are $545 \pm 55 \mathrm{GtC}$ $\left(2000 \pm 200 \mathrm{GtCO}_{2}\right)$ for total emissions, with about $75 \%$ contribution from $E_{\mathrm{FF}}(400 \pm 20 \mathrm{GtC})$ and about $25 \%$ contribution from $E_{\mathrm{LUC}}(145 \pm 50 \mathrm{GtC})$. Cumulative emissions since year 1870 are higher than the emissions of 515 [445 to 585] GtC reported in the IPCC (Stocker et al., 2013b) because they include an additional $32 \mathrm{GtC}$ from emissions in 2012-2014 (mostly from $E_{\mathrm{FF}}$ ). The uncertainty presented here $( \pm 1 \sigma)$ is smaller than the range of $90 \%$ used by the IPCC, but both estimates overlap within their uncertainty ranges.

\section{Discussion}

Each year when the global carbon budget is published, each component for all previous years is updated to take into account corrections that are due to further scrutiny and verification of the underlying data in the primary input data sets. The updates have generally been relatively small and focused on the most recent years, except for LUC, where they are more significant but still generally within the provided uncertainty range (Fig. 9). The difficulty in accessing land-cover-change data to estimate $E_{\mathrm{LUC}}$ is the key problem to providing continuous records of emissions in this sector. Current FAO estimates are based on statistics reported at the country level and are not spatially explicit. Advances in satellite recovery of land-cover change could help to keep track of LUC through time (Achard et al., 2014; Harris et al., 2014). Revisions in $E_{\text {LUC }}$ for the 2008/2009 budget were the result of the release of FAO 2010, which contained a major update to forest-cover change for the period 2000-2005 and provided the data for the following 5 years to 2010 (Fig. 9b). The differences in this year could be attributable to both the different data and the different methods. Updates to values for any give year in each component of the global carbon budget were highest at $0.34 \mathrm{GtC} \mathrm{yr}^{-1}$ for the atmospheric growth rate, $0.19 \mathrm{GtC} \mathrm{yr}^{-1}$ for the fossil fuel and cement emissions, and $0.1 \mathrm{GtC} \mathrm{yr}^{-1}$ for the ocean $\mathrm{CO}_{2}$ sink, all within the reported uncertainty. The update for the residual land $\mathrm{CO}_{2}$ sink was also large (Fig. 9e), with a maximum value of $0.71 \mathrm{GtC} \mathrm{yr}^{-1}$, directly reflecting revisions in other terms of the budget, but still within the reported uncertainty. 
Table 10. Cumulative $\mathrm{CO}_{2}$ emissions for the periods 1750-2013, 1870-2013, and 1870-2014 in gigatonnes of carbon. All uncertainties are reported as $\pm 1 \sigma$. All values are rounded to the nearest $5 \mathrm{GtC}$ as in Stocker et al. (2013b), reflecting the limits of our capacity to constrain cumulative estimates. Thus some columns will not exactly balance because of rounding errors.

\begin{tabular}{lccc}
\hline & $1750-2013(\mathrm{GtC})$ & $1870-2013(\mathrm{GtC})$ & $1870-2014(\mathrm{GtC})$ \\
\hline $\begin{array}{l}\text { Emissions } \\
\begin{array}{l}\text { Fossil fuel combustion and cement production } \\
\left(E_{\mathrm{FF}}\right)\end{array}\end{array}$ & $395 \pm 20$ & $390 \pm 20$ & $400 \pm 20^{*}$ \\
\hline Land-use-change emissions $\left(E_{\mathrm{LUC}}\right)$ & $185 \pm 65$ & $145 \pm 50$ & $145 \pm 50^{*}$ \\
\hline Total emissions & $580 \pm 70$ & $535 \pm 55$ & $545 \pm 55^{*}$ \\
\hline $\begin{array}{l}\text { Partitioning } \\
\text { Atmospheric growth rate }\left(G_{\mathrm{ATM}}\right)\end{array}$ & $250 \pm 5$ & $225 \pm 5$ & $150 \pm 20$ \\
\hline Ocean sink $\left(S_{\mathrm{OCEAN}}\right)$ & $170 \pm 20$ & $155 \pm 60$ & \\
\hline Residual terrestrial sink $\left(S_{\mathrm{LAND}}\right)$ & $160 \pm 70$ & & \\
\hline$*$
\end{tabular}

Our capacity to separate the carbon budget components can be evaluated by comparing the land $\mathrm{CO}_{2}$ sink estimated through three approaches: $(1)$ the budget residual ( $\left.S_{\text {LAND }}\right)$, which includes errors and biases from all components; (2) the land $\mathrm{CO}_{2}$ sink estimate by the DGVM ensemble, which are based on our understanding of processes of how the land responds to increasing $\mathrm{CO}_{2}$, climate, and variability; and (3) the inverse model estimates which formally merge observational constraints with process-based models to close the global budget. These estimates are generally close (Fig. 6), both for the mean and for the interannual variability. The DGVM mean over 1959 to 2013 correlates with the budget residual with $r=0.71$ (Sect. 2.5.2; Fig. 6). The DGVMs produce a decadal mean and standard deviation across models of $2.6 \pm 0.9 \mathrm{GtC} \mathrm{yr}^{-1}$ for the period 2000-2009, nearly the same as the estimate produced with the budget residual (Table 7). New insights from the comparison with the atmospheric inversions and their regional breakdown already provide a semi-independent way to validate the results. The comparison shows a first-order consistency but a lot of discrepancies, particularly for the allocation of the mean land sink between the tropics and the Northern Hemisphere. Understanding these discrepancies and further analysis of regional carbon budgets would provide additional information to quantify and improve our estimates, as has been undertaken by the project REgional Carbon Cycle Assessment and Processes (RECAPP; Canadell et al., 2012).

Annual estimates of each component of the global carbon budgets have their limitations, some of which could be improved with better data and/or better understanding of carbon dynamics. The primary limitations involve resolving fluxes on annual timescales and providing updated estimates for recent years for which data-based estimates are not yet available or only beginning to emerge. Of the various terms in the global budget, only the burning of fossil fuels and at- mospheric growth rate terms are based primarily on empirical inputs supporting annual estimates in this carbon budget. The data on fossil fuel consumption and cement production are based on survey data in all countries. The other terms can be provided on an annual basis only through the use of models. While these models represent the current state of the art, they provide only simulated changes in primary carbon budget components. For example, the decadal trends in global ocean uptake and the interannual variations associated with El Niño-Southern Oscillation (ENSO) are not directly constrained by observations, although many of the processes controlling these trends are sufficiently well known that the model-based trends still have value as benchmarks for further validation. Data-based products for the ocean $\mathrm{CO}_{2}$ sink provide new ways to evaluate the model results, and could be used directly as data become more rapidly available and methods for creating such products improve. Estimates of land-use emissions and their year-to-year variability have even larger uncertainty, and much of the underlying data are not available as an annual update. Efforts are underway to work with annually available satellite area change data or FAO reported data in combination with fire data and modelling to provide annual updates for future budgets. The best resolved changes are in atmospheric growth $\left(G_{\mathrm{ATM}}\right)$, fossil fuel emissions $\left(E_{\mathrm{FF}}\right)$, and, by difference, the change in the sum of the remaining terms $\left(S_{\text {OCEAN }}+S_{\text {LAND }}-E_{\text {LUC }}\right)$. The variations from year to year in these remaining terms are largely model-based at this time. Further efforts to increase the availability and use of annual data for estimating the remaining terms with annual to decadal resolution are especially needed.

Our approach also depends on the reliability of the energy and land-cover-change statistics provided at the country level, and are thus potentially subject to biases. Thus it is critical to develop multiple ways to estimate the carbon balance 
at the global and regional level, including estimates from the inversion of atmospheric $\mathrm{CO}_{2}$ concentration used here for the first time, the use of other oceanic and atmospheric tracers, and the compilation of emissions using alternative statistics (e.g. sectors). It is also important to challenge the consistency of information across observational streams, for example to contrast the coherence of temperature trends with those of $\mathrm{CO}_{2}$ sink trends. Multiple approaches ranging from global to regional scale would greatly help increase confidence and reduce uncertainty in $\mathrm{CO}_{2}$ emissions and their fate.

\section{Conclusions}

The estimation of global $\mathrm{CO}_{2}$ emissions and sinks is a major effort by the carbon cycle research community that requires a combination of measurements and compilation of statistical estimates and results from models. The delivery of an annual carbon budget serves two purposes. First, there is a large demand for up-to-date information on the state of the anthropogenic perturbation of the climate system and its underpinning causes. A broad stakeholder community relies on the data sets associated with the annual carbon budget, including scientists, policy makers, businesses, journalists, and the broader society increasingly engaged in adapting to and mitigating human-driven climate change. Second, over the last decade we have seen unprecedented changes in the human and biophysical environments (e.g. increase in the growth of fossil fuel emissions, ocean temperatures, and strength of the land sink), which call for more frequent assessments of the state of the planet, and by implications a better understanding of the future evolution of the carbon cycle, and the requirements for climate change mitigation and adaptation. Both the ocean and the land surface presently remove a large fraction of anthropogenic emissions. Any significant change in the function of carbon sinks is of great importance to climate policymaking, as they affect the excess carbon dioxide remaining in the atmosphere and therefore the compatible emissions for any climate stabilisation target. Better constraints of carbon cycle models against contemporary data sets raises the capacity for the models to become more accurate at future projections.

This all requires more frequent, robust, and transparent data sets and methods that can be scrutinised and replicated. After nine annual releases from the GCP, the effort is growing and the traceability of the methods has become increasingly complex. Here, we have documented in detail the data sets and methods used to compile the annual updates of the global carbon budget, explained the rationale for the choices made and the limitations of the information, and finally highlighted the need for additional information where gaps exist.

This paper, via "living data", will help to keep track of new budget updates. The evolution over time of the carbon budget is now a key indicator of the anthropogenic perturbation of the climate system, and its annual delivery joins a set of other climate indicators to monitor the evolution of humaninduced climate change, such as the annual updates on the global surface temperature, sea level rise, minimum Arctic sea ice extent, and others.

\section{Data access}

The data presented here are made available in the belief that their wide dissemination will lead to greater understanding and new scientific insights into how the carbon cycle works, how humans are altering it, and how we can mitigate the resulting human-driven climate change. The free availability of these data does not constitute permission for publication of the data. For research projects, if the data are essential to the work, or if an important result or conclusion depends on the data, co-authorship may need to be considered. Full contact details and information on how to cite the data are given at the top of each page in the accompanying database and summarised in Table 2.

The accompanying database includes an Excel file organised in the following spreadsheets (accessible with the free viewer http://www.microsoft.com/en-us/download/ details.aspx?id=10):

1. Summary;

2. The global carbon budget (1959-2013);

3. Global $\mathrm{CO}_{2}$ emissions from fossil fuel combustion and cement production by fuel type, and the per capita emissions (1959-2013);

4. Territorial (e.g. as reported to the UN Framework Convention on Climate Change) country $\mathrm{CO}_{2}$ emissions from fossil fuel combustion and cement production (1959-2013);

5. Consumption country $\mathrm{CO}_{2}$ emissions from fossil fuel combustion and cement production and emissions transfer from the international trade of goods and services (1990-2012);

6. Emissions transfers (consumption minus territorial emissions; 1990-2012);

7. $\mathrm{CO}_{2}$ emissions from land-use change from the individual methods and models (1959-2013);

8. Ocean $\mathrm{CO}_{2}$ sink from the individual ocean models and data products (1959-2013);

9. Terrestrial residual $\mathrm{CO}_{2}$ sink from the DGVMs (19592013);

10. Additional information on the carbon balance prior to 1959 (1750-2013);

11. Country definitions. 
Appendix A: Additional ocean data combined with SOCATv2 and used by the ocean data products

Table A1. Attribution of $f \mathrm{CO}_{2}$ measurements for years 2012-2013 used in addition to SOCAT v2 (Bakker et al., 2014) to inform ocean data products.

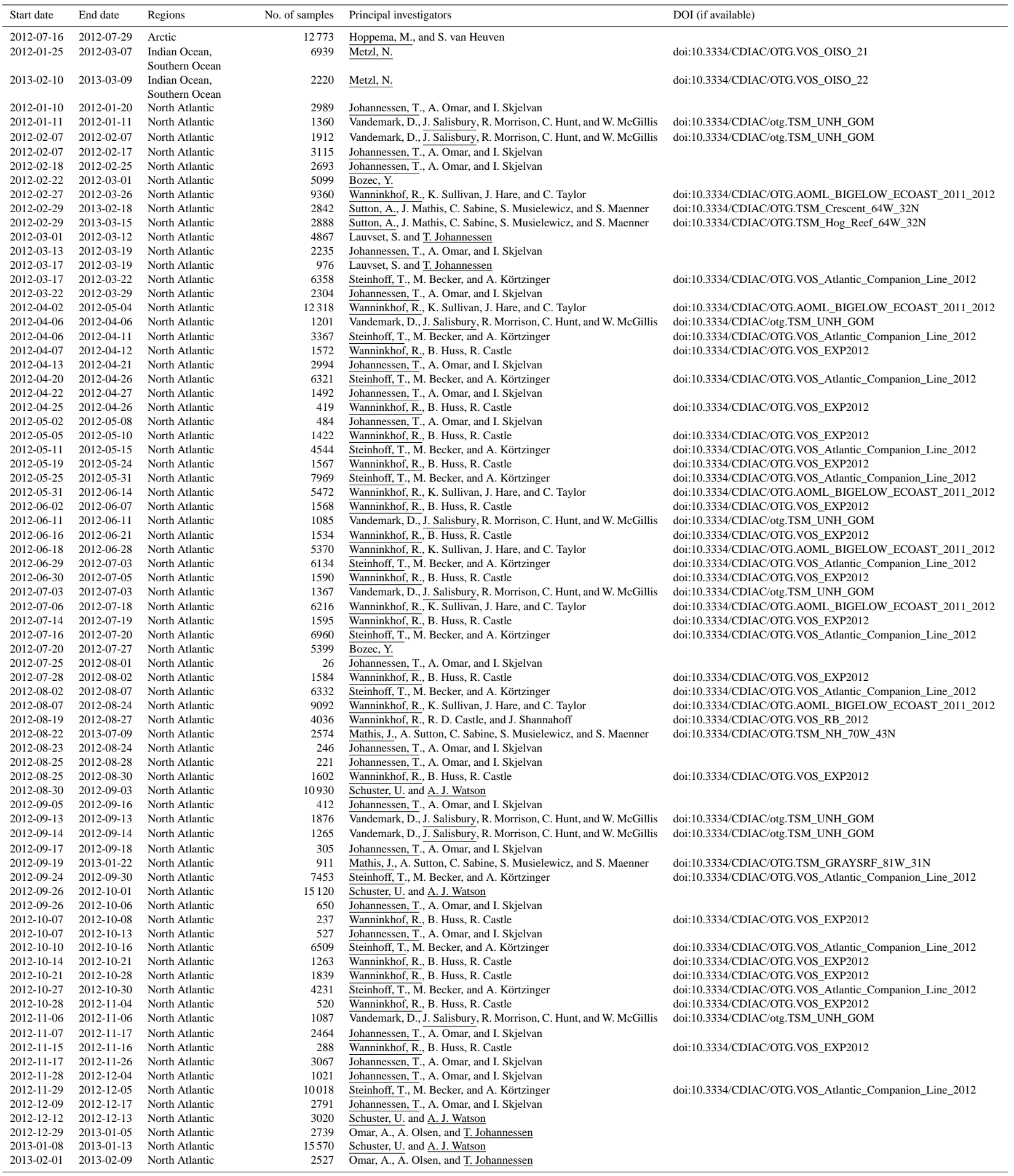


Table A1. Continued.

\begin{tabular}{|c|c|c|}
\hline Start date & End date & Regions \\
\hline 2013-02-12 & 2013-02-16 & North Atlantic \\
\hline 2013-02-12 & 2013-02-21 & North Atlantic \\
\hline 2013-02-21 & 2013-03-01 & North Atlantic \\
\hline 2013-03-05 & 2013-03-12 & North Atlantic \\
\hline 2013-03-14 & 2013-05-09 & North Atlantic \\
\hline 2013-03-21 & 2013-03-26 & North Atlantic \\
\hline 2013-04-15 & 2013-04-15 & North Atlantic \\
\hline 2013-04-16 & 2013-04-26 & North Atlantic \\
\hline 2013-04-27 & 2013-05-02 & North Atlantic \\
\hline 2013-05-06 & 2013-05-11 & North Atlantic \\
\hline $2013-05-21$ & $2013-05-21$ & North Atlantic \\
\hline 2013-05-29 & 2013-06-06 & North Atlantic \\
\hline 2013-06-07 & 2013-06-12 & North Atlantic \\
\hline 2013-06-12 & 2013-06-24 & North Atlantic \\
\hline 2013-06-18 & $2013-06-21$ & North Atlantic \\
\hline 2013-07-01 & 2013-08-18 & North Atlantic \\
\hline 2013-07-10 & 2013-07-19 & North Atlantic \\
\hline 2013-07-18 & $2013-07-28$ & North Atlantic \\
\hline 2013-07-19 & $2013-07-23$ & North Atlantic \\
\hline 2013-08-15 & 2013-08-15 & North Atlantic \\
\hline 2013-09-03 & 2013-11-19 & North Atlantic \\
\hline 2013-09-11 & 2013-09-17 & North Atlantic \\
\hline 2013-09-18 & 2013-09-24 & North Atlantic \\
\hline 2013-10-01 & 2013-10-06 & North Atlantic \\
\hline 2013-10-04 & 2013-10-09 & North Atlantic \\
\hline $2013-10-22$ & 2013-10-31 & North Atlantic \\
\hline 2013-10-27 & 2013-11-03 & North Atlantic \\
\hline 2013-11-01 & 2013-11-10 & North Atlantic \\
\hline 2013-11-02 & 2013-11-06 & North Atlantic \\
\hline 2013-11-18 & $2013-11-23$ & North Atlantic \\
\hline 2013-11-22 & 2013-11-24 & North Atlantic \\
\hline 2013-11-24 & 2013-12-01 & North Atlantic \\
\hline 2013-12-05 & 2013-12-11 & North Atlantic \\
\hline $2013-12-22$ & $2013-12-23$ & North Atlantic \\
\hline $2013-12-28$ & 2013-12-31 & North Atlantic \\
\hline 2012-06-15 & 2012-07-14 & North Atlantic, Arctic \\
\hline 2012-07-02 & $2012-07-20$ & North Atlantic, Arctic \\
\hline $2012-07-23$ & $2012-08-13$ & North Atlantic, Arctic \\
\hline $2012-08-03$ & $2012-10-06$ & North Atlantic, Arctic \\
\hline 2013-07-15 & 2013-08-16 & North Atlantic, Arctic \\
\hline 2013-08-20 & 2013-08-30 & North Atlantic, Arctic \\
\hline 2013-09-01 & 2013-09-09 & North Atlantic, Arctic \\
\hline 2012-01-07 & $2012-01-15$ & North Atlantic, tropical Atlantic \\
\hline 2012-01-29 & $2012-02-06$ & North Atlantic, tropical Atlantic \\
\hline 2012-02-05 & 2012-02-10 & North Atlantic, tropical Atlantic \\
\hline 2012-02-06 & $2012-02-17$ & North Atlantic, tropical Atlantic \\
\hline $2012-02-16$ & 2012-03-05 & North Atlantic, tropical Atlantic \\
\hline $2012-02-17$ & $2012-02-27$ & North Atlantic, tropical Atlantic \\
\hline $2012-02-27$ & 2012-03-09 & North Atlantic, tropical Atlantic \\
\hline 2012-03-09 & 2012-03-19 & North Atlantic, tropical Atlantic \\
\hline 2012-03-17 & $2012-03-21$ & North Atlantic, tropical Atlantic \\
\hline 2012-03-19 & 2012-03-30 & North Atlantic, tropical Atlantic \\
\hline 2012-03-30 & 2012-04-07 & North Atlantic, tropical Atlantic \\
\hline 2012-04-11 & 2012-04-19 & North Atlantic, tropical Atlantic \\
\hline $2012-04-12$ & $2012-04-21$ & North Atlantic, tropical Atlantic \\
\hline 2012-04-26 & 2012-05-05 & North Atlantic, tropical Atlantic \\
\hline $2012-04-28$ & 2012-05-06 & North Atlantic, tropical Atlantic \\
\hline 2012-05-09 & $2012-05-16$ & North Atlantic, tropical Atlantic \\
\hline $2012-05-10$ & 2012-05-19 & North Atlantic, tropical Atlantic \\
\hline $2012-05-24$ & 2012-06-02 & North Atlantic, tropical Atlantic \\
\hline $2012-05-26$ & $2012-06-03$ & North Atlantic, tropical Atlantic \\
\hline 2012-06-07 & 2012-06-16 & North Atlantic, tropical Atlantic \\
\hline $2012-06-21$ & $2012-06-30$ & North Atlantic, tropical Atlantic \\
\hline 2012-07-03 & $2012-07-15$ & North Atlantic, tropical Atlantic \\
\hline 2012-07-04 & $2012-07-12$ & North Atlantic, tropical Atlantic \\
\hline 2012-07-05 & $2012-07-14$ & North Atlantic, tropical Atlantic \\
\hline 2012-07-19 & $2012-07-28$ & North Atlantic, tropical Atlantic \\
\hline 2012-08-01 & 2012-08-09 & North Atlantic, tropical Atlantic \\
\hline $2012-08-02$ & $2012-08-08$ & North Atlantic, tropical Atlantic \\
\hline $2012-08-16$ & $2012-08-25$ & North Atlantic, tropical Atlantic \\
\hline 2012-08-30 & 2012-09-04 & North Atlantic, tropical Atlantic \\
\hline $2012-10-24$ & 2012-11-01 & North Atlantic, tropical Atlantic \\
\hline 2012-11-04 & $2012-11-15$ & North Atlantic, tropical Atlantic \\
\hline $2012-11-21$ & 2012-11-29 & North Atlantic, tropical Atlantic \\
\hline $2012-12-20$ & $2012-12-26$ & North Atlantic, tropical Atlantic \\
\hline 2013-01-16 & 2013-01-21 & North Atlantic, tropical Atlantic \\
\hline 2013-02-02 & 2013-02-08 & North Atlantic, tropical Atlantic \\
\hline 2013-02-14 & 2013-02-21 & North Atlantic, tropical Atlantic \\
\hline 2013-03-02 & 2013-03-10 & North Atlantic, tropical Atlantic \\
\hline 2013-04-22 & 2013-04-27 & North Atlantic, tropical Atlantic \\
\hline 2013-05-02 & 2013-05-11 & North Atlantic, tropical Atlantic \\
\hline 2013-05-04 & 2013-05-09 & North Atlantic, tropical Atlantic \\
\hline 2013-05-16 & $2013-05-25$ & North Atlantic, tropical Atlantic \\
\hline 2013-05-18 & $2013-05-26$ & North Atlantic, tropical Atlantic \\
\hline 2013-05-30 & 2013-06-06 & North Atlantic, tropical Atlantic \\
\hline 2013-06-15 & 2013-06-23 & North Atlantic, tropical Atlantic \\
\hline $2013-06-26$ & 2013-07-04 & North Atlantic, tropical Atlantic \\
\hline 2013-07-13 & $2013-07-21$ & North Atlantic, tropical Atlantic \\
\hline $2013-07-24$ & 2013-08-01 & North Atlantic, tropical Atlantic \\
\hline 2013-08-03 & 2013-10-02 & North Atlantic, tropical Atlantic \\
\hline 2013-08-10 & 2013-08-18 & North Atlantic, tropical Atlantic \\
\hline 2013-08-21 & 2013-08-29 & North Atlantic, tropical Atlantic \\
\hline 2013-09-07 & 2013-09-15 & North Atlantic, tropical Atlantic \\
\hline 2013-09-18 & 2013-09-27 & North Atlantic, tropical Atlantic \\
\hline $2013-10-05$ & 2013-10-13 & North Atlantic, tropical Atlantic \\
\hline
\end{tabular}


Table A1. Continued.

\begin{tabular}{|c|c|c|c|c|c|}
\hline Start date & End date & Regions & No. of samples & Principal investigators & DOI (if available) \\
\hline 2013-10-16 & 2013-10-24 & North Atlantic, tropical Atlantic & 22330 & Schuster, U. and A. J. Watson & \\
\hline 2013-11-02 & 2013-11-10 & North Atlantic, tropical Atlantic & 23040 & 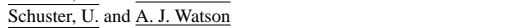 & \\
\hline 2013-11-03 & 2013-11-14 & North Atlantic, tropical Atlantic & 3847 & Wanninkhof, R., B. Huss, K. Sullivan, and R. Castle & doi:10.3334/CDIAC/OTG.VOS_EXP2013 \\
\hline 2013-11-13 & 2013-11-20 & North Atlantic, tropical Atlantic & 20720 & Schuster, U. and A. J. Watson & \\
\hline 2013-11-14 & 2013-11-23 & North Atlantic, tropical Atlantic & 3136 & $\overline{\text { Wanninkhof, R., B. Huss, K. Sullivan, and R. Castle }}$ & doi:10.3334/CDIAC/OTG.VOS_EXP2013 \\
\hline 2013-11-23 & 2013-12-02 & North Atlantic, tropical Atlantic & 2476 & $\overline{\text { Wanninkhof, R., B. Huss, K. Sullivan, and R. Castle }}$ & doi:10.3334/CDIAC/OTG.VOS_EXP2013 \\
\hline 2013-11-30 & 2013-12-08 & North Atlantic, tropical Atlantic & 23980 & $\overline{\text { Schuster, U. and A. J. Watson }}$ & \\
\hline 2013-12-02 & 2013-12-12 & North Atlantic, tropical Atlantic & 3402 & $\overline{\text { Wanninkhof, R., B. Huss, K. Sullivan, and R. Castle }}$ & doi:10.3334/CDIAC/OTG.VOS_EXP2013 \\
\hline 2013-12-12 & 2013-12-22 & North Atlantic, tropical Atlantic & 4082 & Wanninkhof, R., B. Huss, K. Sullivan, and R. Castle & doi:10.3334/CDIAC/OTG.VOS_EXP2013 \\
\hline 2012-06-14 & 2012-07-11 & $\begin{array}{l}\text { North Atlantic, tropical Atlantic, } \\
\text { North Pacific, tropical Pacific }\end{array}$ & 3955 & $\overline{\text { Nojiri, Y. }}$ & doi:10.3334/CDIAC/otg.VOS_Pyxis_Lines \\
\hline 2012-04-11 & 2012-05-14 & $\begin{array}{l}\text { North Atlantic, tropical Atlantic, } \\
\text { Southern Ocean }\end{array}$ & 31606 & Hoppema, M., and S. van Heuven & \\
\hline 2012-01-16 & 2012-01-16 & North Pacific & 94 & Nojiri, Y. & doi:10.3334/CDIAC/OTG.VOS_TF5_2012 \\
\hline 2012-01-18 & 2012-01-22 & North Pacific & 712 & $\overline{\text { Nojiri, Y. }}$ & doi:10.3334/CDIAC/OTG.VOS_TF5_2012 \\
\hline 2012-02-02 & 2012-02-16 & North Pacific & 2032 & $\overline{\text { Nojiri, } Y \text {. }}$ & doi:10.3334/CDIAC/otg.VOS_Pyxis_Lines \\
\hline 2012-02-03 & 2012-02-04 & North Pacific & 162 & Nojiri, Y. & doi:10.3334/CDIAC/OTG.VOS_TF5_2012 \\
\hline 2012-02-15 & 2012-02-15 & North Pacific & 85 & $\overline{\text { Nojiri, Y. }}$ & doi:10.3334/CDIAC/OTG.VOS_TF5_2012 \\
\hline 2012-02-17 & $2012-02-17$ & North Pacific & 89 & $\overline{\text { Nojiri, Y. }}$ & doi:10.3334/CDIAC/OTG.VOS_TF5_2012 \\
\hline 2012-02-20 & 2012-03-01 & North Pacific & 3184 & 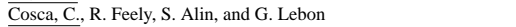 & doi:10.3334/CDIAC/otg.VOS_Bell_Shimada/BS_2012 \\
\hline 2012-03-03 & 2012-03-18 & North Pacific & 2192 & $\overline{\text { Nojiri, Y. }}$ & doi:10.3334/CDIAC/otg.VOS_Pyxis_Lines \\
\hline 2012-03-24 & 2013-03-18 & North Pacific & 2877 & $\overline{\text { Mathis, J., A. Sutton, C. Sabine, S. Musielewicz, and S. Maenner }}$ & doi:10.3334/CDIAC/otg.TSM_CCE2_121W_34N \\
\hline 2012-03-26 & 2012-03-27 & North Pacific & 86 & $\overline{\text { Nojiri, Y. }}$ & doi:10.3334/CDIAC/OTG.VOS_TF5_2012 \\
\hline 2012-03-31 & 2012-03-31 & North Pacific & 91 & $\overline{\text { Nojiri, Y. }}$ & doi:10.3334/CDIAC/OTG.VOS_TF5_2012 \\
\hline 2012-04-12 & 2012-04-21 & North Pacific & 1353 & $\overline{\text { Saito, S., and A. Nakadate }}$ & doi:10.3334/CDIAC/OTG.VOS_KeifuMaru_2001_2012 \\
\hline 2012-04-18 & 2012-05-01 & North Pacific & 1918 & $\overline{\text { Nojiri, Y. }}$ & doi:10.3334/CDIAC/otg.VOS_Pyxis_Lines \\
\hline 2012-05-02 & 2012-05-13 & North Pacific & 1504 & $\overline{\text { Nojiri, Y. }}$ & doi:10.3334/CDIAC/otg.VOS_Pyxis_Lines \\
\hline 2012-05-07 & 2012-05-08 & North Pacific & 87 & $\overline{\text { Nojiri, Y. }}$ & doi:10.3334/CDIAC/OTG.VOS_TF5_2012 \\
\hline 2012-05-11 & 2012-05-11 & North Pacific & 83 & $\overline{\text { Nojiri, } Y .}$ & doi:10.3334/CDIAC/OTG.VOS_TF5_2012 \\
\hline 2012-05-16 & 2012-05-29 & North Pacific & 1914 & $\overline{\text { Nojiri, }, \mathrm{Y}}$ & doi:10.3334/CDIAC/otg.VOS_Pyxis_Lines \\
\hline 2012-05-22 & 2012-06-18 & North Pacific & 30171 & 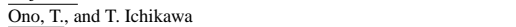 & doi:10.3334/CDIAC/OTG.FRA_SY2012 \\
\hline $2012-05-26$ & 2013-01-18 & North Pacific & 1964 & $\frac{\text { Mathis, J., A. Sutton, C. Sabine, S. Musielewicz, S. Maenner, and }}{\text { R. Bott }}$ & doi:10.3334/CDIAC/otg.TSM_LaPush_125W_48N \\
\hline 2012-05-30 & 2012-06-10 & North Pacific & 1599 & Nojiri, Y. & doi:10.3334/CDIAC/otg.VOS_Pyxis_Lines \\
\hline 2012-06-02 & 2012-06-12 & North Pacific & 1185 & $\overline{\text { Saito, S., and A. Nakadate }}$ & doi:10.3334/CDIAC/OTG.VOS_KeifuMaru_2001_2012 \\
\hline 2012-06-15 & 2012-07-07 & North Pacific & 9030 & Takahashi, T., C. Sweeney, and S. C. Sutherland & doi:10.3334/CDIAC/OTG.VOS_MG_LANGSETH_LINES \\
\hline 2012-06-18 & 2012-06-18 & North Pacific & 85 & Nojiri, Y. & doi:10.3334/CDIAC/OTG.VOS_TF5_2012 \\
\hline 2012-06-22 & $2012-06-22$ & North Pacific & 89 & $\overline{\text { Nojiri, } Y .}$ & doi:10.3334/CDIAC/OTG.VOS_TF5_2012 \\
\hline $2012-06-25$ & 2012-07-08 & North Pacific & 17941 & 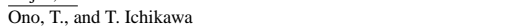 & doi:10.3334/CDIAC/OTG.FRA_WK2012 \\
\hline 2012-07-12 & $2012-07-24$ & North Pacific & 4805 & Takahashi, T., C. Sweeney, and S. C. Sutherland & doi:10.3334/CDIAC/OTG.VOS_MG_LANGSETH_LINES \\
\hline 2012-07-12 & 2012-09-29 & North Pacific & 520 & Mathis, J., A. Sutton, C. Sabine, S. Musielewicz, and S. Maenner & doi:10.3334/CDIAC/OTG.TSM_Dabob_122W_478N \\
\hline 2012-07-17 & $2012-07-26$ & North Pacific & 4363 & 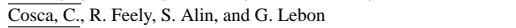 & doi:10.3334/CDIAC/otg.VOS_Bell_Shimada/BS_2012 \\
\hline $2012-07-26$ & 2012-09-10 & North Pacific & 4722 & Saito, S., and A. Nakadate & doi:10.3334/CDIAC/OTG.VOS_Ryofu_Maru_2010_2013 \\
\hline 2012-07-29 & 2012-08-06 & North Pacific & 1185 & Nojiri, Y. & doi:10.3334/CDIAC/otg.VOS_Pyxis_Lines \\
\hline 2012-07-30 & 2012-07-30 & North Pacific & 33 & $\overline{\text { Nojiri, } Y .}$ & doi:10.3334/CDIAC/OTG.VOS_TF5_2012 \\
\hline 2012-07-30 & 2012-08-04 & North Pacific & 1968 & Takahashi, T., C. Sweeney, and S. C. Sutherland & doi:10.3334/CDIAC/otg.VOS_CGC_Healy_Lines \\
\hline 2012-08-03 & 2012-08-03 & North Pacific & 88 & Nojiri, Y. & doi:10.3334/CDIAC/OTG.VOS_TF5_2012 \\
\hline 2012-08-09 & 2013-09-05 & North Pacific & 3062 & 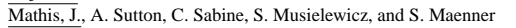 & doi:10.3334/CDIAC/OTG.TSM_WA_125W_47N \\
\hline 2012-08-13 & $2012-08-25$ & North Pacific & 1792 & Nojiri, Y. & doi:10.3334/CDIAC/otg.VOS_Pyxis_Lines \\
\hline 2012-08-17 & $2012-08-26$ & North Pacific & 3710 & Takahashi, T., C. Sweeney, and S. C. Sutherland & doi:10.3334/CDIAC/OTG.VOS_MG_LANGSETH_LINES \\
\hline 2012-08-27 & 2012-09-08 & North Pacific & 1745 & $\overline{\text { Nojiri, Y. }}$ & doi:10.3334/CDIAC/otg.VOS_Pyxis_Lines \\
\hline 2012-09-05 & 2012-09-17 & North Pacific & 5637 & 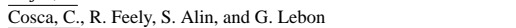 & doi:10.3334/CDIAC/otg.VOS_Bell_Shimada/BS_2012 \\
\hline 2012-09-10 & 2012-09-10 & North Pacific & 87 & Nojiri, Y. & doi:10.3334/CDIAC/OTG.VOS_TF5_2012 \\
\hline 2012-09-14 & 2012-09-14 & North Pacific & 79 & $\overline{\text { Nojiri, }, \mathrm{Y}}$ & doi:10.3334/CDIAC/OTG.VOS_TF5_2012 \\
\hline 2012-09-15 & 2012-09-28 & North Pacific & 1858 & $\overline{\text { Nojiri, Y. }}$ & doi:10.3334/CDIAC/otg.VOS_Pyxis_Lines \\
\hline 2012-10-06 & 2012-10-21 & North Pacific & 17804 & 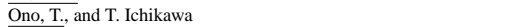 & doi:10.3334/CDIAC/OTG.FRA_WK2012 \\
\hline $2012-10-18$ & 2012-11-02 & North Pacific & 2139 & Nojiri, Y. & doi:10.3334/CDIAC/otg.VOS_Pyxis_Lines \\
\hline $2012-10-22$ & $2012-10-23$ & North Pacific & 92 & Nojiri, Y. & doi:10.3334/CDIAC/OTG.VOS_TF5_2012 \\
\hline 2012-11-16 & 2012-12-06 & North Pacific & 1767 & $\overline{\text { Saito, S., and A. Nakadate }}$ & doi:10.3334/CDIAC/OTG.VOS_Ryofu_Maru_2010_2013 \\
\hline $2012-11-21$ & 2012-12-07 & North Pacific & 2320 & $\overline{\text { Nojiri, Y. }}$ & doi:10.3334/CDIAC/otg.VOS_Pyxis_Lines \\
\hline 2012-12-03 & 2012-12-03 & North Pacific & 92 & $\overline{\text { Nojiri, Y. }}$ & doi:10.3334/CDIAC/OTG.VOS_TF5_2012 \\
\hline 2012-12-07 & 2012-12-07 & North Pacific & 82 & $\overline{\text { Nojiri, Y. }}$ & doi:10.3334/CDIAC/OTG.VOS_TF5_2012 \\
\hline $2012-12-25$ & 2013-01-08 & North Pacific & 2079 & Nojiri, Y. & doi:10.3334/CDIAC/otg.VOS_Pyxis_Lines \\
\hline 2013-01-09 & 2013-01-21 & North Pacific & 1619 & $\overline{\text { Nojiri, } Y .}$ & doi:10.3334/CDIAC/otg.VOS_Pyxis_Lines \\
\hline $2013-01-25$ & 2013-02-08 & North Pacific & 2065 & $\overline{\text { Nojiri, Y. }}$ & doi:10.3334/CDIAC/otg.VOS_Pyxis_Lines \\
\hline 2013-01-28 & 2013-01-28 & North Pacific & 96 & $\overline{\text { Nojiri, Y. }}$ & doi:10.3334/CDIAC/OTG.VOS_TF5_2013 \\
\hline 2013-02-09 & 2013-02-21 & North Pacific & 1748 & Nojiri, Y. & doi:10.3334/CDIAC/otg.VOS_Pyxis_Lines \\
\hline 2013-02-25 & 2013-03-13 & North Pacific & 2328 & $\overline{\text { Nojiri, } Y .}$ & doi:10.3334/CDIAC/otg.VOS_Pyxis_Lines \\
\hline 2013-03-07 & 2013-09-25 & North Pacific & 1616 & 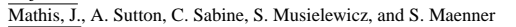 & doi:10.3334/CDIAC/OTG.TSM_GAKOA_149W_60N \\
\hline 2013-03-11 & 2013-03-12 & North Pacific & 91 & $\overline{\text { Nojiri, Y. }}$ & doi:10.3334/CDIAC/OTG.VOS_TF5_2013 \\
\hline 2013-03-29 & 2013-04-11 & North Pacific & 1917 & $\overline{\text { Nojiri, Y. }}$ & doi:10.3334/CDIAC/otg.VOS_Pyxis_Lines \\
\hline 2013-03-29 & $2013-08-22$ & North Pacific & 1175 & $\begin{array}{l}\overline{\text { Mathis, J., }} \\
\text { R. Aott Sutton, C. Sabine, S. Musielewicz, S. Maenner, and }\end{array}$ & doi:10.3334/CDIAC/OTG.TSM_Southeast_AK_56N_134W \\
\hline 2013-03-30 & $2013-10-20$ & North Pacific & 1633 & $\frac{\text { Mathis, J., A. Sutton, C. Sabine, S. Musielewicz, S. Maenner, and }}{\text { R. Bott }}$ & doi:10.3334/CDIAC/OTG.TSM_KODIAK_152W_57N \\
\hline 2013-04-12 & 2013-04-25 & North Pacific & 1758 & Nojiri, Y. & doi:10.3334/CDIAC/otg.VOS_Pyxis_Lines \\
\hline 2013-04-22 & 2013-04-22 & North Pacific & 91 & $\overline{\text { Nojiri, Y. }}$ & doi:10.3334/CDIAC/OTG.VOS_TF5_2013 \\
\hline 2013-04-24 & 2013-09-24 & North Pacific & 1811 & $\begin{array}{l}\overline{\text { Mathis, J., A. Sutton, C. Sabine, S. Musielewicz, S. Maenner, and }} \text { R. Bott }\end{array}$ & doi:10.3334/CDIAC/otg.TSM_LaPush_125W_48N \\
\hline 2013-04-26 & 2013-04-26 & North Pacific & 80 & Nojiri, Y. & doi:10.3334/CDIAC/OTG.VOS_TF5_2013 \\
\hline
\end{tabular}


Table A1. Continued.

\begin{tabular}{|c|c|c|c|c|c|}
\hline Start date & End date & Regions & No. of samples & Principal investigators & DOI (if available) \\
\hline 2013-05-06 & 2013-09-14 & North Pacific & 1053 & $\frac{\text { Mathis, J., A. Sutton, C. Sabine, S. Musielewicz, S. Maenner, and }}{\text { R. Bott }}$ & doi:10.3334/CDIAC/OTG.TSM_M2_164W_57N \\
\hline 2013-05-31 & 2013-06-16 & North Pacific & 1960 & Saito, S., and A. Nakadate & doi:10.3334/CDIAC/OTG.VOS_KeifuMaru_2012_2013 \\
\hline 2013-06-03 & 2013-06-04 & North Pacific & 99 & Nojiri, Y. & doi:10.3334/CDIAC/OTG.VOS_TF5_2013 \\
\hline 2013-06-07 & 2013-06-07 & North Pacific & 88 & $\overline{\text { Nojiri, Y. }}$ & doi:10.3334/CDIAC/OTG.VOS_TF5_2013 \\
\hline 2013-07-15 & 2013-07-15 & North Pacific & 95 & Nojiri, Y. & doi:10.3334/CDIAC/OTG.VOS_TF5_2013 \\
\hline 2013-07-19 & 2013-07-19 & North Pacific & 86 & $\overline{\text { Nojiri, Y. }}$ & doi:10.3334/CDIAC/OTG.VOS_TF5_2013 \\
\hline 2012-08-12 & 2012-09-27 & North Pacific, Arctic & 20409 & Takahashi, T., C. Sweeney, and S. C. Sutherland & doi:10.3334/CDIAC/otg.VOS_CGC_Healy_Lines \\
\hline 2012-10-05 & $2012-10-24$ & North Pacific, Arctic & 8690 & Takahashi, T., C. Sweeney, and S. C. Sutherland & doi:10.3334/CDIAC/otg.VOS_CGC_Healy_Lines \\
\hline 2012-01-08 & 2012-01-24 & North Pacific, tropical Pacific & 1890 & Saito, S., and A. Nakadate & doi:10.3334/CDIAC/OTG.VOS_KeifuMaru_2001_2012 \\
\hline 2012-01-11 & $2012-02-26$ & North Pacific, tropical Pacific & 4205 & Saito, S., and A. Nakadate & doi:10.3334/CDIAC/OTG.VOS_Ryofu_Maru_2010_2013 \\
\hline 2012-01-16 & 2012-01-30 & North Pacific, tropical Pacific & 2078 & Nojiri, Y. & doi:10.3334/CDIAC/otg.VOS_Pyxis_Lines \\
\hline 2012-02-03 & $2012-03-22$ & North Pacific, tropical Pacific & 5941 & $\overline{\text { Saito, S., and A. Nakadate }}$ & doi:10.3334/CDIAC/OTG.VOS_KeifuMaru_2001_2012 \\
\hline 2012-02-11 & 2012-02-14 & North Pacific, tropical Pacific & 440 & $\overline{\text { Nojiri, Y. }}$ & doi:10.3334/CDIAC/OTG.VOS_TF5_2012 \\
\hline $2012-02-17$ & 2012-03-01 & North Pacific, tropical Pacific & 1891 & Nojiri, Y. & doi:10.3334/CDIAC/otg.VOS_Pyxis_Lines \\
\hline $2012-02-18$ & 2012-02-27 & North Pacific, tropical Pacific & 1284 & $\overline{\text { Nojiri, Y. }}$ & doi:10.3334/CDIAC/OTG.VOS_TF5_2012 \\
\hline 2012-03-07 & 2012-03-23 & North Pacific, tropical Pacific & 1918 & $\overline{\text { Saito, S., and A. Nakadate }}$ & doi:10.3334/CDIAC/OTG.VOS_Ryofu_Maru_2010_2013 \\
\hline $2012-03-20$ & $2012-04-03$ & North Pacific, tropical Pacific & 2018 & Nojiri, Y. & doi:10.3334/CDIAC/otg.VOS_Pyxis_Lines \\
\hline 2012-03-27 & 2012-04-04 & North Pacific, tropical Pacific & 3791 & $\overline{\text { Cosca, C., R. Feely, S. Alin, and G. Lebon }}$ & doi:10.3334/CDIAC/otg.VOS_Bell_Shimada/BS_2012 \\
\hline 2012-04-01 & 2012-04-11 & North Pacific, tropical Pacific & 1441 & Nojiri, Y. & doi:10.3334/CDIAC/OTG.VOS_TF5_2012 \\
\hline 2012-04-10 & 2012-05-09 & North Pacific, tropical Pacific & 3351 & $\overline{\text { Saito, S., and A. Nakadate }}$ & doi:10.3334/CDIAC/OTG.VOS_Ryofu_Maru_2010_2013 \\
\hline 2012-04-16 & 2012-04-26 & North Pacific, tropical Pacific & 9655 & $\overline{\text { Ono, T., and T. Ichikawa }}$ & doi:10.3334/CDIAC/OTG.FRA_SY2012 \\
\hline 2012-04-29 & 2012-05-27 & North Pacific, tropical Pacific & 3263 & 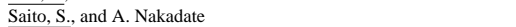 & doi:10.3334/CDIAC/OTG.VOS_KeifuMaru_2001_2012 \\
\hline 2012-05-12 & $2012-05-21$ & North Pacific, tropical Pacific & 1375 & Nojiri, Y. & doi:10.3334/CDIAC/OTG.VOS_TF5_2012 \\
\hline 2012-05-13 & 2012-06-07 & North Pacific, tropical Pacific & 8620 & Takahashi, T., C. Sweeney, and S. C. Sutherland & doi:10.3334/CDIAC/OTG.VOS_MG_LANGSETH_LINES \\
\hline 2012-06-02 & 2012-07-12 & North Pacific, tropical Pacific & 3846 & $\overline{\text { Saito, S., and A. Nakadate }}$ & doi:10.3334/CDIAC/OTG.VOS_Ryofu_Maru_2010_2013 \\
\hline 2012-06-21 & 2012-08-17 & North Pacific, tropical Pacific & 5485 & $\overline{\text { Saito, S., and A. Nakadate }}$ & doi:10.3334/CDIAC/OTG.VOS_KeifuMaru_2001_2012 \\
\hline $2012-06-23$ & 2012-07-02 & North Pacific, tropical Pacific & 1374 & Nojiri, Y. & doi:10.3334/CDIAC/OTG.VOS_TF5_2012 \\
\hline 2012-08-04 & $2012-08-15$ & North Pacific, tropical Pacific & 1580 & Nojiri, Y. & doi:10.3334/CDIAC/OTG.VOS_TF5_2012 \\
\hline 2012-08-26 & 2012-09-10 & North Pacific, tropical Pacific & 1775 & $\overline{\text { Saito, S., and A. Nakadate }}$ & doi:10.3334/CDIAC/OTG.VOS_KeifuMaru_2001_2012 \\
\hline $2012-09-15$ & $2012-09-24$ & North Pacific, tropical Pacific & 1384 & Nojiri, Y. & doi:10.3334/CDIAC/OTG.VOS_TF5_2012 \\
\hline 2012-09-29 & 2012-10-13 & North Pacific, tropical Pacific & 1882 & $\overline{\text { Nojiri, Y. }}$ & doi:10.3334/CDIAC/otg.VOS_Pyxis_Lines \\
\hline 2012-10-24 & 2012-12-01 & North Pacific, tropical Pacific & 3554 & $\overline{\text { Saito, S., and A. Nakadate }}$ & doi:10.3334/CDIAC/OTG.VOS_KeifuMaru_2001_2012 \\
\hline $2012-10-26$ & 2012-11-06 & North Pacific, tropical Pacific & 1644 & Nojiri, Y. & doi:10.3334/CDIAC/OTG.VOS_TF5_2012 \\
\hline 2012-10-29 & 2012-11-29 & North Pacific, tropical Pacific & 31251 & $\overline{\text { Ono, T., and T. Ichikawa }}$ & doi:10.3334/CDIAC/OTG.FRA_SY2012 \\
\hline 2012-11-03 & 2012-11-19 & North Pacific, tropical Pacific & 2335 & Nojiri, Y. & doi:10.3334/CDIAC/otg.VOS_Pyxis_Lines \\
\hline 2012-12-08 & $2012-12-20$ & North Pacific, tropical Pacific & 1835 & Nojiri, Y. & doi:10.3334/CDIAC/otg.VOS_Pyxis_Lines \\
\hline 2012-12-09 & 2012-12-17 & North Pacific, tropical Pacific & 1263 & $\overline{\text { Nojiri, Y. }}$ & doi:10.3334/CDIAC/OTG.VOS_TF5_2012 \\
\hline $2012-12-10$ & $2012-12-17$ & North Pacific, tropical Pacific & 800 & $\overline{\text { Saito, S., and A. Nakadate }}$ & doi:10.3334/CDIAC/OTG.VOS_KeifuMaru_2012_2013 \\
\hline 2013-01-07 & 2013-01-24 & North Pacific, tropical Pacific & 1995 & $\overline{\text { Saito, S., and A. Nakadate }}$ & doi:10.3334/CDIAC/OTG.VOS_KeifuMaru_2012_2013 \\
\hline 2013-01-09 & 2013-02-27 & North Pacific, tropical Pacific & 3990 & Saito, S., and A. Nakadate & doi:10.3334/CDIAC/OTG.VOS_Ryofu_Maru_2010_2013 \\
\hline 2013-02-01 & 2013-02-12 & North Pacific, tropical Pacific & 1537 & Nojiri, Y. & doi:10.3334/CDIAC/OTG.VOS_TF5_2013 \\
\hline 2013-02-03 & 2013-03-24 & North Pacific, tropical Pacific & 4530 & $\overline{\text { Saito, S., and A. Nakadate }}$ & doi:10.3334/CDIAC/OTG.VOS_KeifuMaru_2012_2013 \\
\hline 2013-03-07 & 2013-03-24 & North Pacific, tropical Pacific & 2084 & $\overline{\text { Saito, S., and A. Nakadate }}$ & doi:10.3334/CDIAC/OTG.VOS_Ryofu_Maru_2010_2013 \\
\hline 2013-03-14 & 2013-03-27 & North Pacific, tropical Pacific & 1892 & $\overline{\text { Nojiri, Y. }}$ & doi:10.3334/CDIAC/otg.VOS_Pyxis_Lines \\
\hline 2013-03-15 & 2013-03-25 & North Pacific, tropical Pacific & 1396 & $\overline{\text { Nojiri, Y. }}$ & doi:10.3334/CDIAC/OTG.VOS_TF5_2013 \\
\hline 2013-04-11 & 2013-05-05 & North Pacific, tropical Pacific & 1980 & $\overline{\text { Saito, S., and A. Nakadate }}$ & doi:10.3334/CDIAC/OTG.VOS_KeifuMaru_2012_2013 \\
\hline 2013-04-26 & 2013-05-08 & North Pacific, tropical Pacific & 1430 & $\overline{\text { Saito, S., and A. Nakadate }}$ & doi:10.3334/CDIAC/OTG.VOS_Ryofu_Maru_2010_2013 \\
\hline 2013-04-27 & 2013-05-07 & North Pacific, tropical Pacific & 1512 & Nojiri, Y. & doi:10.3334/CDIAC/OTG.VOS_TF5_2013 \\
\hline 2013-06-08 & 2013-06-17 & North Pacific, tropical Pacific & 1375 & $\overline{\text { Nojiri, Y. }}$ & doi:10.3334/CDIAC/OTG.VOS_TF5_2013 \\
\hline 2013-06-21 & $2013-07-22$ & North Pacific, tropical Pacific & 3085 & $\overline{\text { Saito, S., and A. Nakadate }}$ & doi:10.3334/CDIAC/OTG.VOS_Ryofu_Maru_2010_2013 \\
\hline $2013-06-26$ & $2013-08-27$ & North Pacific, tropical Pacific & 5730 & Saito, S., and A. Nakadate & doi:10.3334/CDIAC/OTG.VOS_KeifuMaru_2012_2013 \\
\hline 2013-07-20 & 2013-07-30 & North Pacific, tropical Pacific & 1478 & Nojiri, Y. & doi:10.3334/CDIAC/OTG.VOS_TF5_2013 \\
\hline 2013-07-31 & 2013-09-13 & North Pacific, tropical Pacific & 4535 & $\overline{\text { Saito, S., and A. Nakadate }}$ & doi:10.3334/CDIAC/OTG.VOS_Ryofu_Maru_2010_2013 \\
\hline 2012-01-03 & $2012-01-15$ & $\begin{array}{l}\text { North Pacific, tropical Pacific, } \\
\text { Southern Ocean }\end{array}$ & 1687 & Nojiri, Y. & doi:10.3334/CDIAC/OTG.VOS_TF5_2012 \\
\hline 2012-01-24 & 2012-02-05 & $\begin{array}{l}\text { North Pacific, tropical Pacific, } \\
\text { Southern Ocean }\end{array}$ & 4936 & Cosca, C., R. Feely, S. Alin, and G. Lebon & doi:10.3334/CDIAC/OTG.VOS_NATALIE_SCHULTE_LINES \\
\hline 2012-02-16 & $2012-02-29$ & $\begin{array}{l}\text { North Pacific, tropical Pacific, } \\
\text { Southern Ocean }\end{array}$ & 5898 & Cosca, C., R. Feely, S. Alin, and G. Lebon & doi:10.3334/CDIAC/OTG.VOS_NATALIE_SCHULTE_LINES \\
\hline 2012-03-12 & $2012-03-25$ & $\begin{array}{l}\text { North Pacific, tropical Pacific, } \\
\text { Southern Ocean }\end{array}$ & 1743 & Nojiri, Y. & doi:10.3334/CDIAC/OTG.VOS_TF5_2012 \\
\hline 2012-04-16 & 2012-05-03 & $\begin{array}{l}\text { North Pacific, tropical Pacific, } \\
\text { Southern Ocean }\end{array}$ & 6673 & Cosca, C., R. Feely, S. Alin, and G. Lebon & doi:10.3334/CDIAC/OTG.VOS_NATALIE_SCHULTE_LINES \\
\hline 2012-04-24 & 2012-05-06 & $\begin{array}{l}\text { North Pacific, tropical Pacific, } \\
\text { Southern Ocean }\end{array}$ & 1724 & Nojiri, Y. & doi:10.3334/CDIAC/OTG.VOS_TF5_2012 \\
\hline 2012-06-05 & 2012-06-17 & $\begin{array}{l}\text { North Pacific, tropical Pacific, } \\
\text { Southern Ocean }\end{array}$ & 1806 & Nojiri, Y. & doi:10.3334/CDIAC/OTG.VOS_TF5_2012 \\
\hline 2012-06-08 & $2012-06-21$ & $\begin{array}{l}\text { North Pacific, tropical Pacific, } \\
\text { Southern Ocean }\end{array}$ & 5745 & Cosca, C., R. Feely, S. Alin, and G. Lebon & doi:10.3334/CDIAC/OTG.VOS_NATALIE_SCHULTE_LINES \\
\hline $2012-07-16$ & $2012-07-29$ & $\begin{array}{l}\text { North Pacific, tropical Pacific, } \\
\text { Southern Ocean }\end{array}$ & 1739 & Nojiri, Y. & doi:10.3334/CDIAC/OTG.VOS_TF5_2012 \\
\hline $2012-08-28$ & 2012-09-09 & $\begin{array}{l}\text { North Pacific, tropical Pacific, } \\
\text { Southern Ocean }\end{array}$ & 1760 & Nojiri, Y. & doi:10.3334/CDIAC/OTG.VOS_TF5_2012 \\
\hline 2012-10-09 & $2012-10-21$ & $\begin{array}{l}\text { North Pacific, tropical Pacific, } \\
\text { Southern Ocean }\end{array}$ & 1720 & Nojiri, Y. & doi:10.3334/CDIAC/OTG.VOS_TF5_2012 \\
\hline $2012-11-21$ & $2012-12-02$ & $\begin{array}{l}\text { North Pacific, tropical Pacific, } \\
\text { Southern Ocean }\end{array}$ & 1711 & Nojiri, Y. & doi:10.3334/CDIAC/OTG.VOS_TF5_2012 \\
\hline 2013-01-13 & $2013-01-26$ & $\begin{array}{l}\text { North Pacific, tropical Pacific, } \\
\text { Southern Ocean }\end{array}$ & 1853 & Nojiri, Y. & doi:10.3334/CDIAC/OTG.VOS_TF5_2013 \\
\hline
\end{tabular}


Table A1. Continued.

\begin{tabular}{|c|c|c|c|c|c|}
\hline Start date & End date & Regions & No. of samples & Principal investigators & DOI (if available) \\
\hline 2013-02-27 & 2013-03-10 & $\begin{array}{l}\text { North Pacific, tropical Pacific, } \\
\text { Southern Ocean }\end{array}$ & 1716 & Nojiri, Y. & doi:10.3334/CDIAC/OTG.VOS_TF5_2013 \\
\hline 2013-04-08 & 2013-04-20 & $\begin{array}{l}\text { North Pacific, tropical Pacific, } \\
\text { Southern Ocean }\end{array}$ & 1725 & Nojiri, Y. & doi:10.3334/CDIAC/OTG.VOS_TF5_2013 \\
\hline 2013-05-21 & 2013-06-02 & $\begin{array}{l}\text { North Pacific, tropical Pacific, } \\
\text { Southern Ocean }\end{array}$ & 1734 & $\underline{\text { Nojiri, Y. }}$ & doi:10.3334/CDIAC/OTG.VOS_TF5_2013 \\
\hline 2013-07-02 & 2013-07-14 & $\begin{array}{l}\text { North Pacific, tropical Pacific, } \\
\text { Southern Ocean }\end{array}$ & 1735 & $\underline{\text { Nojiri, Y. }}$ & doi:10.3334/CDIAC/OTG.VOS_TF5_2013 \\
\hline 2013-08-14 & 2013-08-25 & $\begin{array}{l}\text { North Pacific, tropical Pacific, } \\
\text { Southern Ocean }\end{array}$ & 1697 & Nojiri, Y. & doi:10.3334/CDIAC/OTG.VOS_TF5_2013 \\
\hline 2012-01-05 & 2012-02-11 & Southern Ocean & 37047 & Tilbrook, B., C. Neill, and J. Akl & doi:10.3334/CDIAC/OTG.VOS_AA_2012 \\
\hline 2012-01-07 & 2012-01-12 & Southern Ocean & 3783 & Tilbrook, B., C. Neill, and J. Akl & doi:10.3334/CDIAC/OTG.VOS_AL_2012 \\
\hline 2012-01-08 & 2012-03-10 & Southern Ocean & 61324 & $\overline{\text { Hoppema, M., and S. van Heuven }}$ & \\
\hline 2012-01-23 & 2012-01-30 & Southern Ocean & 4471 & 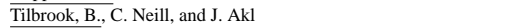 & doi:10.3334/CDIAC/OTG.VOS_AL_2012 \\
\hline $2012-02-13$ & 2012-03-10 & Southern Ocean & 5165 & Takahashi, T., C. Sweeney, and S. C. Sutherland & doi:10.3334/CDIAC/otg.VOS_LM_Gould_Lines \\
\hline 2012-02-15 & 2012-03-14 & Southern Ocean & 22626 & Tilbrook, B., C. Neill, and J. Akl & doi:10.3334/CDIAC/OTG.VOS_AA_2012 \\
\hline 2012-02-18 & 2012-02-25 & Southern Ocean & 5270 & $\overline{T i l b r o o k, ~ B ., ~ C . ~ N e i l l, ~ a n d ~ J . ~ A k l ~}$ & doi:10.3334/CDIAC/OTG.VOS_AL_2012 \\
\hline 2012-03-02 & 2012-03-06 & Southern Ocean & 3868 & Tilbrook, B., C. Neill, and J. Akl & doi:10.3334/CDIAC/OTG.VOS_AL_2012 \\
\hline 2012-03-13 & 2012-04-17 & Southern Ocean & 13582 & Takahashi, T., C. Sweeney, and S. C. Sutherland & doi:10.3334/CDIAC/otg.VOS_NB_Palmer_Lines \\
\hline 2012-03-17 & 2012-04-14 & Southern Ocean & 21211 & Tilbrook, B., C. Neill, and J. Akl & doi:10.3334/CDIAC/OTG.VOS_AA__2012 \\
\hline 2012-03-18 & 2012-04-02 & Southern Ocean & 3598 & Takahashi, T., C. Sweeney, and S. C. Sutherland & doi:10.3334/CDIAC/otg.VOS_LM_Gould_Lines \\
\hline 2012-03-18 & 2012-04-08 & Southern Ocean & 20946 & $\overline{\text { Hoppema, M., and S. van Heuven }}$ & \\
\hline 2012-04-09 & 2012-04-27 & Southern Ocean & 3497 & $\overline{\text { Takahashi, T., C. Sweeney, and S. C. Sutherland }}$ & doi:10.3334/CDIAC/otg.VOS_LM_Gould_Lines \\
\hline 2012-04-11 & 2012-04-15 & Southern Ocean & 1772 & 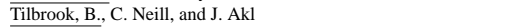 & doi:10.3334/CDIAC/OTG.VOS_SS_2012 \\
\hline 2012-04-16 & 2012-05-01 & Southern Ocean & 5357 & Tilbrook, B., C. Neill, and J. Akl & doi:10.3334/CDIAC/OTG.VOS_AA_2012 \\
\hline 2012-05-03 & 2012-05-30 & Southern Ocean & 4216 & 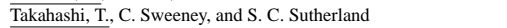 & doi:10.3334/CDIAC/otg.VOS_LM_Gould_Lines \\
\hline 2012-06-07 & 2012-06-22 & Southern Ocean & 2688 & Takahashi, T., C. Sweeney, and S. C. Sutherland & doi:10.3334/CDIAC/otg.VOS_LM_Gould_Lines \\
\hline 2012-07-11 & $2012-07-24$ & Southern Ocean & 10369 & Tilbrook, B., C. Neill, and J. Akl & doi:10.3334/CDIAC/OTG.VOS_SS_2012 \\
\hline 2012-07-14 & 2012-09-24 & Southern Ocean & 577 & 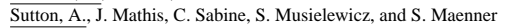 & doi:10.3334/CDIAC/OTG.TSM_SOFS_142W_46S \\
\hline 2012-08-03 & 2012-08-15 & Southern Ocean & 3877 & Takahashi, T., C. Sweeney, and S. C. Sutherland & doi:10.3334/CDIAC/otg.VOS_NB_Palmer_Lines \\
\hline 2012-08-31 & 2012-09-05 & Southern Ocean & 1637 & $\overline{\text { Takahashi, T., C. Sweeney, and S. C. Sutherland }}$ & doi:10.3334/CDIAC/otg.VOS_NB_Palmer_Lines \\
\hline 2012-09-17 & 2012-11-15 & Southern Ocean & 59272 & 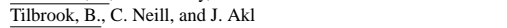 & doi:10.3334/CDIAC/OTG.VOS_AA__2012 \\
\hline 2012-09-19 & $2012-10-03$ & Southern Ocean & 2945 & Takahashi, T., C. Sweeney, and S. C. Sutherland & doi:10.3334/CDIAC/otg.VOS_LM_Gould_Lines \\
\hline 2012-10-11 & 2012-10-15 & Southern Ocean & 1581 & Takahashi, T., C. Sweeney, and S. C. Sutherland & doi:10.3334/CDIAC/otg.VOS_LM_Gould_Lines \\
\hline $2012-10-23$ & $2012-10-28$ & Southern Ocean & 3119 & Tilbrook, B., C. Neill, and J. Akl & doi:10.3334/CDIAC/OTG.VOS_AL_2013 \\
\hline 2012-11-05 & 2012-11-22 & Southern Ocean & 2986 & Takahashi, T., C. Sweeney, and S. C. Sutherland & doi:10.3334/CDIAC/otg.VOS_LM_Gould_Lines \\
\hline 2012-11-15 & 2013-01-02 & Southern Ocean & 367 & Kitidis, V. & doi:10.3334/CDIAC/OTG.VOS_JCR_2013 \\
\hline 2012-11-18 & 2012-11-22 & Southern Ocean & 3050 & Tilbrook, B., C. Neill, and J. Akl & doi:10.3334/CDIAC/OTG.VOS_AL_2013 \\
\hline 2012-11-18 & $2012-12-14$ & Southern Ocean & 23322 & 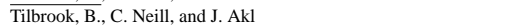 & doi:10.3334/CDIAC/OTG.VOS_AA_2012 \\
\hline 2012-12-17 & 2013-01-07 & Southern Ocean & 22758 & Tilbrook, B., C. Neill, and J. Akl & doi:10.3334/CDIAC/OTG.VOS_AA_2012 \\
\hline $2012-12-31$ & 2013-02-06 & Southern Ocean & 13005 & 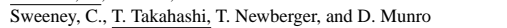 & doi:10.3334/CDIAC/OTG.VOS_LMG_NOAA_2013 \\
\hline 2013-01-09 & 2013-01-11 & Southern Ocean & 27 & Kitidis, V. & doi:10.3334/CDIAC/OTG.VOS_JCR_2013 \\
\hline 2013-01-10 & 2013-01-15 & Southern Ocean & 3819 & Tilbrook, B., C. Neill, and J. Akl & doi:10.3334/CDIAC/OTG.VOS_AL_2013 \\
\hline 2013-01-13 & 2013-01-27 & Southern Ocean & 15015 & Tilbrook, B., C. Neill, and J. Akl & doi:10.3334/CDIAC/OTG.VOS_AA_2013 \\
\hline 2013-01-26 & 2013-01-31 & Southern Ocean & 3682 & Tilbrook, B., C. Neill, and J. Akl & doi:10.3334/CDIAC/OTG.VOS_AL_2013 \\
\hline 2013-02-13 & 2013-02-24 & Southern Ocean & 2370 & 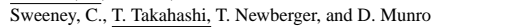 & doi:10.3334/CDIAC/OTG.VOS_LMG_NOAA_2013 \\
\hline 2013-02-19 & $2013-02-25$ & Southern Ocean & 3917 & Tilbrook, B., C. Neill, and J. Akl & doi:10.3334/CDIAC/OTG.VOS_AL_2013 \\
\hline 2013-02-26 & 2013-03-04 & Southern Ocean & 4104 & $\overline{T i l b r o o k, ~ B ., ~ C . ~ N e i l l, ~ a n d ~ J . ~ A k l ~}$ & doi:10.3334/CDIAC/OTG.VOS_AL_2013 \\
\hline 2013-02-26 & 2013-03-13 & Southern Ocean & 83 & $\overline{\text { Kitidis, V. }}$ & doi:10.3334/CDIAC/OTG.VOS_JCR_2013 \\
\hline 2013-02-27 & 2013-03-14 & Southern Ocean & 16461 & Tilbrook, B., C. Neill, and J. Akl & doi:10.3334/CDIAC/OTG.VOS_AA_2013 \\
\hline 2013-03-11 & 2013-04-07 & Southern Ocean & 4797 & 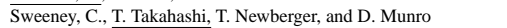 & doi:10.3334/CDIAC/OTG.VOS_LMG_NOAA_2013 \\
\hline 2013-03-18 & 2013-04-27 & Southern Ocean & 798 & Kitidis, V. & doi:10.3334/CDIAC/OTG.VOS_JCR_2013 \\
\hline 2013-04-13 & 2013-05-05 & Southern Ocean & 4808 & $\overline{\text { Sweeney, C., T. Takahashi, T. Newberger, and D. Munro }}$ & doi:10.3334/CDIAC/OTG.VOS_LMG_NOAA_2013 \\
\hline 2013-05-12 & 2013-05-24 & Southern Ocean & 3670 & Sweeney, C., T. Takahashi, T. Newberger, and D. Munro & doi:10.3334/CDIAC/OTG.VOS_LMG_NOAA_2013 \\
\hline 2013-06-01 & 2013-07-05 & Southern Ocean & 4438 & Sweeney, C., T. Takahashi, T. Newberger, and D. Munro & doi:10.3334/CDIAC/OTG.VOS_LMG_NOAA_2013 \\
\hline 2013-09-14 & 2013-09-26 & Southern Ocean & 3974 & Sweeney, C., T. Takahashi, T. Newberger, and D. Munro & doi:10.3334/CDIAC/OTG.VOS_LMG_NOAA_2013 \\
\hline 2013-10-05 & 2013-10-22 & Southern Ocean & 2669 & Sweeney, C., T. Takahashi, T. Newberger, and D. Munro & doi:10.3334/CDIAC/OTG.VOS_LMG_NOAA_2013 \\
\hline 2013-10-28 & 2013-11-15 & Southern Ocean & 4428 & Sweeney, C., T. Takahashi, T. Newberger, and D. Munro & doi:10.3334/CDIAC/OTG.VOS_LMG_NOAA_2013 \\
\hline 2013-11-10 & 2013-12-15 & Southern Ocean & 35682 & Hoppema, M., and S. van Heuven & \\
\hline 2013-11-23 & 2013-12-19 & Southern Ocean & 8790 & 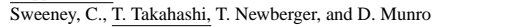 & doi:10.3334/CDIAC/OTG.VOS_LMG_NOAA_2013 \\
\hline 2013-12-21 & 2014-03-01 & Southern Ocean & 71817 & Hoppema, M. and S. van Heuven & \\
\hline $2012-12-10$ & 2014-02-24 & Tropical Atlantic & 3534 & Sutton, A., J. Mathis, C. Sabine, S. Musielewicz, and S. Maenner & doi:10.3334/CDIAC/OTG.CHEECA_80W_25N \\
\hline 2013-05-02 & 2013-06-16 & $\begin{array}{l}\text { Tropical Atlantic, } \\
\text { Southern Ocean }\end{array}$ & 2338 & $\overline{\overline{\text { Kitidis, }} \text {. }}$. & doi:10.3334/CDIAC/OTG.VOS_JCR_2013 \\
\hline 2013-12-24 & 2014-02-04 & $\begin{array}{l}\text { Tropical Atlantic, } \\
\text { Southern Ocean }\end{array}$ & 21025 & $\underline{\text { Wanninkhof, R., R. D. Castle, and J. Shannahoff }}$ & doi:10.3334/CDIAC/OTG.VOS_RB_2013 \\
\hline 2012-04-18 & 2012-08-30 & Tropical Pacific & 1076 & Sutton, A., J. Mathis, C. Sabine, S. Musielewicz, and S. Maenner & doi:10.3334/CDIAC/OTG.TSM_ALAWAI_158W_21N \\
\hline 2012-04-20 & 2012-04-29 & Tropical Pacific & 6347 & Tilbrook, B., C. Neill, and J. Akl & doi:10.3334/CDIAC/OTG.VOS_SS_2012 \\
\hline 2012-05-02 & 2012-05-09 & Tropical Pacific & 4746 & Tilbrook, B., C. Neill, and J. Akl & doi:10.3334/CDIAC/OTG.VOS_SS_2012 \\
\hline 2012-05-13 & 2012-06-04 & Tropical Pacific & 13723 & Tilbrook, B., C. Neill, and J. Akl & doi:10.3334/CDIAC/OTG.VOS_SS_2012 \\
\hline 2012-08-28 & 2012-09-02 & Tropical Pacific & 1710 & Takahashi, T., C. Sweeney, and S. C. Sutherland & doi:10.3334/CDIAC/otg.VOS_LM_Gould_Lines \\
\hline 2012-02-27 & 2012-03-11 & Tropical Pacific, Southern Ocean & 1442 & Nojiri, Y. & doi:10.3334/CDIAC/OTG.VOS_TF5_2012 \\
\hline 2012-04-11 & 2012-04-23 & Tropical Pacific, Southern Ocean & 1296 & $\overline{\text { Nojiri, Y. }}$ & doi:10.3334/CDIAC/OTG.VOS_TF5_2012 \\
\hline 2012-05-22 & 2012-06-03 & Tropical Pacific, Southern Ocean & 1365 & $\overline{\text { Nojiri, Y. }}$ & doi:10.3334/CDIAC/OTG.VOS_TF5_2012 \\
\hline 2012-06-08 & 2012-06-17 & Tropical Pacific, Southern Ocean & 6006 & Tilbrook, B., C. Neill, and J. Akl & doi:10.3334/CDIAC/OTG.VOS_SS_2012 \\
\hline 2012-07-03 & 2012-07-15 & Tropical Pacific, Southern Ocean & 1359 & $\overline{\text { Nojiri, Y. }}$ & doi:10.3334/CDIAC/OTG.VOS_TF5_2012 \\
\hline 2012-08-15 & 2012-08-27 & Tropical Pacific, Southern Ocean & 1352 & $\overline{\text { Nojiri, Y. }}$ & doi:10.3334/CDIAC/OTG.VOS_TF5_2012 \\
\hline 2012-09-25 & 2012-10-07 & Tropical Pacific, Southern Ocean & 1340 & $\overline{\text { Nojiri, Y. }}$ & doi:10.3334/CDIAC/OTG.VOS_TF5_2012 \\
\hline 2012-11-07 & 2012-11-19 & Tropical Pacific,Southern Ocean & 1295 & Nojiri, Y. & doi:10.3334/CDIAC/OTG.VOS_TF5_2012 \\
\hline $2012-12-18$ & 2013-01-11 & Tropical Pacific, Southern Ocean & 1389 & $\overline{\text { Nojiri, Y. }}$ & doi:10.3334/CDIAC/OTG.VOS_TF5_2012 \\
\hline 2013-02-12 & $2013-02-25$ & Tropical Pacific, Southern Ocean & 1414 & $\overline{\text { Nojiri, } Y .}$ & doi:10.3334/CDIAC/OTG.VOS_TF5_2013 \\
\hline 2013-03-25 & 2013-04-07 & Tropical Pacific, Southern Ocean & 1446 & $\overline{\text { Nojiri, } Y \text {. }}$ & doi:10.3334/CDIAC/OTG.VOS_TF5_2013 \\
\hline 2013-05-08 & 2013-05-20 & Tropical Pacific, Southern Ocean & 1359 & $\overline{\text { Nojiri, } Y .}$ & doi:10.3334/CDIAC/OTG.VOS_TF5_2013 \\
\hline 2013-06-18 & 2013-07-01 & Tropical Pacific, Southern Ocean & 1436 & $\overline{\text { Nojiri, Y. }}$ & doi:10.3334/CDIAC/OTG.VOS_TF5_2013 \\
\hline 2013-07-30 & $2013-08-12$ & Tropical Pacific, Southern Ocean & 1370 & Nojiri, $Y$. & doi:10.3334/CDIAC/OTG.VOS_TF5_2013 \\
\hline
\end{tabular}


Acknowledgements. We thank all people and institutions who provided the data used in this carbon budget; P. Cadule, C. Enright, J. Ghattas, and G. Hurtt for support to the model simulations; D. Bakker for support to the interactions with the ocean $\mathrm{CO}_{2}$ data community; F. Joos and S. Khatiwala for providing historical data; and M. Heimann, G. McKinley, and anonymous reviewers for their comments and suggestions. We thank E. Dlugokencky, who provided the atmospheric and oceanographic $\mathrm{CO}_{2}$ measurements used here, and all those involved in collecting and providing oceanographic data $\mathrm{CO}_{2}$ measurements used here, in particular for the ocean data for years 2012-2013 that are not included in SOCAT v2: J. Akl, S. Alin, M. Becker, R. Bott, R. D. Castle, R.. Feely, J. Hare, C. Hunt, B. Huss, T. Ichikawa, A. Körtzinger, G. Lebon, S. Maenner, J. Mathis, W. McGillis, R. Morrison, D. Munro, S. Musielewicz, A. Nakadate, C. Neill, T. Newberger, A. Omar, C. Sabine, J. Salisbury, J. Shannahoff, I. Skjelvan, K. Sullivan, S. C. Sutherland, A. Sutton, C. Sweeney, C. Taylor, S. van Heuven, D. Vandemark, and A. J. Watson. We thank the institutions and funding agencies responsible for the collection and quality control of the data included in SOCAT, and are grateful for the support from the International Ocean Carbon Coordination Project (IOCCP), the Surface Ocean Lower Atmosphere Study (SOLAS), and the Integrated Marine Biogeochemistry and Ecosystem Research (IMBER) programme, as well as UK Natural Environment Research Council (NERC) projects, including National Capability, Ocean Acidification, Greenhouse Gases, and Shelf Seas Biogeochemistry.

NERC provided funding to C. Le Quéré, R. Moriarty, and the GCP though their International Opportunities Fund specifically to support this publication (NE/103002X/1), and to U. Schuster through UKOARP (NE/H017046/1). G. P. Peters and R. M. Andrews were supported by the Norwegian Research Council (236296). T. A. Boden was supported by US Department of Energy, Office of Science, Biological and Environmental Research (BER) programmes under US Department of Energy contract DEAC05-00OR22725. Y. Bozec was supported by Region Bretagne, CG29, and INSU (LEFE/MERMEX) for CARBORHONE cruises. J. G. Canadell and M. R. Raupach were supported by the Australian Climate Change Science Programme. M. Hoppema received ICOSD funding through the German Federal Ministry of Education and Research (BMBF) to the AWI (01 LK 1224I). J. I. House was supported by a Leverhulme Early Career Fellowship. A. K. Jain was supported by the US National Science Foundation (NSF AGS 12-43071) the US Department of Energy, Office of Science, and BER programmes (DOE DE-SC0006706) and the NASA LCLUC programme (NASA NNX14AD94G). E. Kato was supported by the Environment Research and Technology Development Fund (S-10) of the Ministry of Environment of Japan. C. Koven was supported by the Director, Office of Science, Office of Biological and Environmental Research, of the US Department of Energy under contract no. DE-AC02-05CH11231 as part of their Regional and Global Climate Modeling Program. I. D. Lima was supported by the U.S. National Science Foundation (NSF AGS-1048827). N. Metzl was supported by Institut National des Sciences de l'Univers (INSU) and Institut Paul Emile Victor (IPEV) for OISO cruises. A. Olsen was supported by the Centre for Climate Dynamics at the Bjerknes Centre for Climate Research. J. E. Salisbury was supported by grants from NOAA/NASA. T. Steinhoff was supported by ICOS-D (BMBF FK 01LK1101C). B. D. Stocker was supported by the Swiss National Science Foundation and
FP7 funding through project EMBRACE (282672). A. J. Sutton was supported by NOAA. T. Takahashi was supported by grants from NOAA and the Comer Education and Science Foundation. B. Tilbrook was supported by the Australian Department of the Environment and the Integrated Marine Observing System. A. Wiltshire was supported by the Joint UK DECC/Defra Met Office Hadley Centre Climate Programme (GA01101). P. Ciais, W. Peters, C. Le Quére, P. Regnier, and U. Schuster were supported by the EU FP7 through project GEOCarbon (283080). A. Arneth, P. Ciais, S. Sitch, and A. Wiltshire were supported by COMBINE (226520). V. Kitidis, M. Hoppema, N. Metzl, C. Le Quéré, U. Schuster, J. Schwiger, J. Segschneider, and T. Steinhoff were supported by the EU FP7 through project CARBOCHANGE (264879). A. Arnet, P. Friedlingstein, B. Poulter, and S. Sitch were supported by the EU FP7 through projects LUC4C (GA603542). P. Friedlingstein was also supported by EMBRACE (GA282672). F. Chevallier and G. R. van der Werf were supported by the EU FP7 through project MACC-II (283576). This is NOAA-PMEL contribution number 4216. Contributions from the Scripps Institution of Oceanography were supported by DOE grant DE-SC0005090, NSF grant ATM1036399, and NOAA grant NA10OAR4320156.

Edited by: D. Carlson

\section{References}

Achard, F., Beuchle, R., Mayaux, P., Stibig, H. J., Bodart, C., Brink, A., Carboni, S., Desclée, B., Donnay, F., and Eva, H.: Determination of tropical deforestation rates and related carbon losses from 1990 to 2010, Glob. Change Biol., 20, 2540-2554, 2014.

Andres, R. J., Fielding, D. J., Marland, G., Boden, T. A., Kumar, N., and Kearney, A. T.: Carbon dioxide emissions from fossil fuel use, 1751-1950, Tellus, 51, 759-765, 1999.

Andres, R. J., Boden, T., and Higdon, D.: A new evaluation of the uncertainty associated with CDIAC estimates of fossil fuel carbon dioxide emission, Tellus B, 66, 23616, doi:10.3402/tellusb.v66.23616, 2014.

Andres, R. J., Boden, T. A., Bréon, F.-M., Ciais, P., Davis, S., Erickson, D., Gregg, J. S., Jacobson, A., Marland, G., Miller, J., Oda, T., Olivier, J. G. J., Raupach, M. R., Rayner, P., and Treanton, K.: A synthesis of carbon dioxide emissions from fossil-fuel combustion, Biogeosciences, 9, 1845-1871, doi:10.5194/bg-9-18452012, 2012.

Andrew, R. M. and Peters, G. P.: A multi-region input-output table based on the Global Trade Analysis Project Database (GTAPMRIO), Economic Systems Research, 25, 99-121, 2013.

Archer, D., Eby, M., Brovkin, V., Ridgwell, A., Cao, L., Mikolajewicz, U., Caldeira, K. M. K., Munhoven, G., Montenegro, A., and Tokos, K.: Atmospheric Lifetime of Fossil Fuel Carbon Dioxide, Annu. Rev. Earth Pl. Sc., 37, 117-134, 2009.

Assmann, K. M., Bentsen, M., Segschneider, J., and Heinze, C.: An isopycnic ocean carbon cycle model, Geosci. Model Dev., 3, 143-167, doi:10.5194/gmd-3-143-2010, 2010.

Atlas, R., Hoffman, R. N., Ardizzone, J., Leidner, S. M., Jusem, J. C., Smith, D. K., and Gombos, D.: A cross-calibrated, multiplatform ocean surface wind velocity product for meteorological and oceanographic applications, B. Am. Meteorol. Soc., 92, 157174, 2011. 
Aumont, O. and Bopp, L.: Globalizing results from ocean in situ iron fertilization studies, Global Biogeochem. Cy., 20, GB2017, doi:10.1029/2005GB002591, 2006.

Baccini, A., Goetz, S. J., Walker, W. S., Laporte, N. T., Sun, M., Sulla-Menashe, D., Hackler, J., Beck, P. S. A., Dubayah, R., Friedl, M. A., Samanta, S., and Houghton, R. A.: Estimated carbon dioxide emissions from tropical deforestation improved by carbon-density maps, Nature Clim. Change, 2, 182-186, 2012.

Bakker, D. C. E., Pfeil, B., Smith, K., Hankin, S., Olsen, A., Alin, S. R., Cosca, C., Harasawa, S., Kozyr, A., Nojiri, Y., O’Brien, K. M., Schuster, U., Telszewski, M., Tilbrook, B., Wada, C., Akl, J., Barbero, L., Bates, N. R., Boutin, J., Bozec, Y., Cai, W.-J., Castle, R. D., Chavez, F. P., Chen, L., Chierici, M., Currie, K., de Baar, H. J. W., Evans, W., Feely, R. A., Fransson, A., Gao, Z., Hales, B., Hardman-Mountford, N. J., Hoppema, M., Huang, W.-J., Hunt, C. W., Huss, B., Ichikawa, T., Johannessen, T., Jones, E. M., Jones, S. D., Jutterström, S., Kitidis, V., Körtzinger, A., Landschützer, P., Lauvset, S. K., Lefèvre, N., Manke, A. B., Mathis, J. T., Merlivat, L., Metzl, N., Murata, A., Newberger, T., Omar, A. M., Ono, T., Park, G.-H., Paterson, K., Pierrot, D., Ríos, A. F., Sabine, C. L., Saito, S., Salisbury, J., Sarma, V. V. S. S., Schlitzer, R., Sieger, R., Skjelvan, I., Steinhoff, T., Sullivan, K. F., Sun, H., Sutton, A. J., Suzuki, T., Sweeney, C., Takahashi, T., Tjiputra, J., Tsurushima, N., van Heuven, S. M. A. C., Vandemark, D., Vlahos, P., Wallace, D. W. R., Wanninkhof, R., and Watson, A. J.: An update to the Surface Ocean $\mathrm{CO}_{2}$ Atlas (SOCAT version 2), Earth Syst. Sci. Data, 6, 69-90, doi:10.5194/essd-6-69-2014, 2014.

Ballantyne, A. P., Alden, C. B., Miller, J. B., Tans, P. P., and White, J. W. C.: Increase in observed net carbon dioxide uptake by land and oceans during the last 50 years, Nature, 488, 70-72, 2012.

Bauer, J. E., Cai, W.-J., Raymond, P. A., Bianchi, T. S., Hopkinson, C. S., and Regnier, P. A. G.: The changing carbon cycle of the coastal ocean, Nature, 504, 61-70, 2013.

Best, M. J., Pryor, M., Clark, D. B., Rooney, G. G., Essery, R .L. H., Ménard, C. B., Edwards, J. M., Hendry, M. A., Porson, A., Gedney, N., Mercado, L. M., Sitch, S., Blyth, E., Boucher, O., Cox, P. M., Grimmond, C. S. B., and Harding, R. J.: The Joint UK Land Environment Simulator (JULES), model description Part 1: Energy and water fluxes, Geosci. Model Dev., 4, 677-699, doi:10.5194/gmd-4-677-2011, 2011.

Boden, T. A., Marland, G., and Andres, R. J.: Global, Regional, and National Fossil-Fuel $\mathrm{CO}_{2}$ Emissions, Oak Ridge National Laboratory, U.S. Department of Energy, Oak Ridge, Tenn., USA, 2013.

BP: Statistical Review of World Energy 2014, available at: http://www.bp.com/en/global/corporate/about-bp/ energy-economics/statistical-review-of-world-energy.html, last access: 8 August 2014.

Bruno, M. and Joos, F.: Terrestrial carbon storage during the past 200 years: A monte carlo analysis of $\mathrm{CO}_{2}$ data from ice core and atmospheric measurements, Global Biogeochem. Cy., 11, 111124, 1997

Buitenhuis, E. T., Rivkin, R. B., Sailley, S., and Le Quéré, C.: Biogeochemical fluxes through microzooplankton, Global Biogeochem. Cy., 24, GB4015, doi:10.1029/2009gb003601, 2010.

Canadell, J., Ciais, P., Sabine, C., and Joos, F. (Eds.): REgional Carbon Cycle Assessment and Processes (RECCAP), Special
Issue, Biogeosciences, http://www.biogeosciences.net/special_ issue 107.html, 2012.

Canadell, J. G., Le Quéré, C., Raupach, M. R., Field, C. B., Buitenhuis, E. T., Ciais, P., Conway, T. J., Gillett, N. P., Houghton, R. A., and Marland, G.: Contributions to accelerating atmospheric $\mathrm{CO}_{2}$ growth from economic activity, carbon intensity, and efficiency of natural sinks, P. Natl. Acad. Sci. USA, 104, 1886618870, 2007.

Chevallier, F., Fisher, M., Peylin, P., Serrar, S., Bousquet, P., Bréon, F.-M., Chédin, A., and Ciais, P.: Inferring $\mathrm{CO}_{2}$ sources and sinks from satellite observations: Method and application to TOVS data, J. Geophys. Res., D24309, doi:10.1029/2005JD006390, 2005.

Ciais, P., Sabine, C., Govindasamy, B., Bopp, L., Brovkin, V., Canadell, J., Chhabra, A., DeFries, R., Galloway, J., Heimann, M., Jones, C., Le Quéré, C., Myneni, R., Piao, S., and Thornton, P.: Chapter 6: Carbon and Other Biogeochemical Cycles, in: Climate Change 2013 The Physical Science Basis, edited by: Stocker, T., Qin, D., and Platner, G.-K., Cambridge University Press, Cambridge, 2013.

Clark, D. B., Mercado, L. M., Sitch, S., Jones, C. D., Gedney, N., Best, M. J., Pryor, M., Rooney, G. G., Essery, R. L. H., Blyth, E., Boucher, O., Harding, R. J., Huntingford, C., and Cox, P. M.: The Joint UK Land Environment Simulator (JULES), model description - Part 2: Carbon fluxes and vegetation dynamics, Geosci Model Dev., 4, 701-722, doi:10.5194/gmd-4-701-2011, 2011.

Collins, W. J., Bellouin, N., Doutriaux-Boucher, M., Gedney, N., Halloran, P., Hinton, T., Hughes, J., Jones, C. D., Joshi, M., Liddicoat, S., Martin, G., O’Connor, F., Rae, J., Senior, C., Sitch, S., Totterdell, I., Wiltshire, A., and Woodward, S.: Development and evaluation of an Earth-System model - HadGEM2, Geosci. Model Dev., 4, 1051-1075, doi:10.5194/gmd-4-10512011, 2011.

Cox, P. M., Betts, R. A., Jones, C. D., Spall, S. A., and Totterdell, I. J.: Acceleration of global warming due to carbon-cycle feedbacks in a coupled climate model, Nature, 408, 184-187, 2000.

Danabasoglu, G., Yeager, S. G., Bailey, D., Behrens, E., Bentsen, M., Bi, D., Biastoch, A., Böning, C., Bozec, A., Canuto, V. M., Cassou, C., Chassignet, E., Coward, A. C., Danilov, S., Diansky, N., Drange, H., Farneti, R., Fernandez, E., Fogli, P. G., Forget, G., Fujii, Y., Griffies, S. M., Gusev, A., Heimbach, P., Howard, A., Jung, T., Kelley, M., Large, W. G., Leboissetier, A., Lu, J., Madec, G., Marsland, S. J., Masina, S., Navarra, A., Nurser, A. J. G., Pirani, A., Salas y Mélia, D., Samuels, B. L., Scheinert, M., Sidorenko, D., Treguier, A.-M., Tsujino, H., Uotila, P., Valcke, S., Voldoire, A., and Wangi, Q.: North Atlantic simulations in Coordinated Ocean-ice Reference Experiments phase II (CORE-II). Part I: Mean states, Ocean Model., 73, 76-107, doi:10.1016/j.ocemod.2013.10.005, 2014.

Davis, S. J. and Caldeira, K.: Consumption-based accounting of $\mathrm{CO}_{2}$ emissions, P. Natl. Acad. Sci. USA, 107, 5687-5692, 2010.

Davis, S. J., Peters, G. P., and Caldeira, K.: The supply chain of $\mathrm{CO}_{2}$ emissions, P. Natl. Acad. Sci., 108, 18554-18559, 2011.

Denman, K. L., Brasseur, G., Chidthaisong, A., Ciais, P., Cox, P. M., Dickinson, R. E., Hauglustaine, D., Heinze, C., Holland, E., Jacob, D., Lohmann, U., Ramachandran, S., Leite da Silva Dias, P., Wofsy, S. C., and Zhang, X.: Couplings Between Changes in the Climate System and Biogeochemistry, Intergovernmental 
Panel on Climate Change, ISBN: 978-0-521-70596-7, 499-587, 2007.

Dlugokencky, E. and Tans, P.: Trends in atmospheric carbon dioxide, National Oceanic \& Atmospheric Administration, Earth System Research Laboratory (NOAA/ESRL), available at: http:// www.esrl.noaa.gov/gmd/ccgg/trends, last access: 8 August 2014.

Doney, S. C., Lima, I., Feely, R. A., Glover, D. M., Lindsay, K., Mahowald, N., Moore, J. K., and Wanninkhof, R.: Mechanisms governing interannual variability in upper-ocean inorganic carbon system and air-sea $\mathrm{CO}_{2}$ fluxes: Physical climate and atmospheric dust, Deep-Sea Res. Pt. I, 56, 640-655, 2009.

Durant, A. J., Le Quéré, C., Hope, C., and Friend, A. D.: Economic value of improved quantification in global sources and sinks of carbon dioxide, Philos. T. Roy. Soc. A, 269, 1967-1979, 2010.

Earles, J. M., Yeh, S., and Skog, K. E.: Timing of carbon emissions from global forest clearance, Nature Clim. Change, 2, 682-685, 2012.

El-Masri, B., Barman, R., Meiyappan, P., Song, Y., Liang, M., and Jain, A. K.: Carbon dynamics in the Amazonian Basin: Integration of eddy covariance and ecophysiological data with a land surface model, Agr. Forest Meteorol., 182-183, 156-167, 2013.

Erb, K.-H., Kastner, T., Luyssaert, S., Houghton, R. A., Kuemmerle, T., Olofsson, P., and Haberl, H.: Bias in the attribution of forest carbon sinks, Nature Clim. Change, 3, 854-856, 2013.

Etheridge, D. M., Steele, L. P., Langenfelds, R. L., and Francey, R. $\mathrm{J} .:$ Natural and anthropogenic changes in atmospheric $\mathrm{CO}_{2}$ over the last 1000 years from air in Antarctic ice and firn, J. Geophys. Res., 101, 4115-4128, 1996.

FAO: Global Forest Resource Assessment 2010, Food and Agriculture Organization of the United Nations, Rome 378 pp., 2010.

FAOSTAT: Food and Agriculture Organization Statistics Division, available at: http://faostat.fao.org/2010 (last access: 14 November 2011), 2010.

Francey, R. J., Trudinger, C. M., van der Schoot, M., Law, R. M., Krummel, P. B., Langenfelds, R. L., Steele, L. P., Allison, C. E., Stavert, A. R., Andres, R. J., and Rodenbeck, C.: Reply to "Anthropogenic $\mathrm{CO}_{2}$ emissions" by Raupach et al., Nature Clim. Change, 3, 604-604, 2013.

Friedlingstein, P., Houghton, R. A., Marland, G., Hackler, J., Boden, T. A., Conway, T. J., Canadell, J. G., Raupach, M. R., Ciais, P., and Le Quéré, C.: Update on $\mathrm{CO}_{2}$ emissions, Nat. Geosci., 3, 811-812, 2010.

Friedlingstein, P., Andrew, R. M., Rogelj, J., Peters, G. P., Canadell, J. G., Knutti, R., Luderer, G., Raupach, M. R., Schaeffer, M., van Vuuren, D. P., and Le Quéré, C.: Persistent growth of $\mathrm{CO}_{2}$ emissions and implications for reaching climate targets, Nat. Geosci., 7, 709-715, doi:10.1038/ngeo2248, 2014.

Gasser, T. and Ciais, P.: A theoretical framework for the net landto-atmosphere $\mathrm{CO}_{2}$ flux and its implications in the definition of "emissions from land-use change", Earth Syst. Dynam., 4, 171186, doi:10.5194/esd-4-171-2013, 2013.

GCP: The Global Carbon Budget 2007, available at: http://lgmacweb.env.uea.ac.uk/lequere/co2/2007/carbon_ budget_2007.htm (last access: November 2013), 2007.

Giglio, L., Randerson, J. T., and van der Werf, G. R.: Analysis of daily, monthly, and annual burned area using the fourthgeneration global fire emissions database (GFED4), J. Geophys. Res.-Biogeo., 118, 317-328, doi:10.1002/jgrg.20042, 2013.
Gitz, V. and Ciais, P.: Amplifying effects of land-use change on future atmospheric $\mathrm{CO}_{2}$ levels, Global Biogeochem. Cy., 17, 1024, doi:10.1029/2002GB001963, 2003.

Gregg, J. S., Andres, R. J., and Marland, G.: China: Emissions pattern of the world leader in $\mathrm{CO}_{2}$ emissions from fossil fuel consumption and cement production, Geophys. Res. Lett., 35, L08806, doi:10.1029/2007GL032887, 2008.

Harris, I., Jones, P. D., Osborn, T. J., and Lister, D. H.: Updated high-resolution grids of monthly climatic observations - the CRU TS3.10 Dataset, Int. J. Climatol., 34, 623-642, 2014.

Hertwich, E. G. and Peters, G. P.: Carbon Footprint of Nations: A Global, Trade-Linked Analysis, Environ. Sci. Technol., 43, 6414-6420, 2009.

Houghton, R. A.: Revised estimates of the annual net flux of carbon to the atmosphere from changes in land use and land management 1850-2000, Tellus B, 55, 378-390, 2003.

Houghton, R. A., House, J. I., Pongratz, J., van der Werf, G. R., DeFries, R. S., Hansen, M. C., Le Quéré, C., and Ramankutty, N.: Carbon emissions from land use and land-cover change, Biogeosciences, 9, 5125-5142, doi:10.5194/bg-9-5125-2012, 2012.

Hourdin, F., Musat, I., Bony, S., Braconnot, P., Codron, F., Dufresne, J.-L., Fairhead, L., Filiberti, M.-A., Freidlingstein, P., Grandpeix, J.-Y., Krinner, G., LeVan, P., Li, Z.-X., and Lott, F.: The LMDZ4 general circulation model: climate performance and sensitivity to parametrized physics with emphasis on tropical convection, Clim. Dynam., 27, 787-813, 2006.

Hurtt, G. C., Chini, L. P., Frolking, S., Betts, R. A., Feddema, J., Fischer, G., Fisk, J. P., Hibbard, K., Houghton, R. A., Janetos, A., Jones, C. D., Kindermann, G., Kinoshita, T., Klein Goldewijk, K., Riahi, K., Shevliakova, E., Smith, S., Stehfest, E., Thomson, A., Thornton, P., van Vuuren, D. P., and Wang, Y. P.: Harmonization of land-use scenarios for the period 1500-2100: 600 years of global gridded annual land-use transitions, wood harvest, and resulting secondary lands, Climatic Change, 109, 117-161, 2011.

IEA/OECD: $\mathrm{CO}_{2}$ emissions from fuel combustion, International Energy Agency, Paris, 2013.

Ilyina, T., Six, K., Segschneider, J., Maier-Reimer, E., Li, H., and Núñez-Riboni, I.: The global ocean biogeochemistry model HAMOCC: Model architecture and performance as component of the MPI-Earth System Model in different CMIP5 experimental realizations, Journal of Advances in Modeling Earth Systems, 5, 287-315, 2013.

IMF: World Economic Outlook of the International Monetary Fund, available at: http://www.imf.org/external/ns/cs.aspx?id=29, last access: 14 July 2014.

Ito, A. and Inatomi, M.: Use of a process-based model for assessing the methane budgets of global terrestrial ecosystems and evaluation of uncertainty, Biogeosciences, 9, 759-773, doi:10.5194/bg9-759-2012, 2012.

Jacobson, A. R., Mikaloff Fletcher, S. E., Gruber, N., Sarmiento, J. L., and Gloor, M.: A joint atmosphere-ocean inversion for surface fluxes of carbon dioxide: 1. Methods and global-scale fluxes, Global Biogeochem. Cy., 21, GB1019, doi:10.1029/2005GB002556, 2007.

Jain, A. K., Meiyappan, P., Song, Y., and House, J. I.: $\mathrm{CO}_{2}$ Emissions from Land-Use Change Affected More by Nitrogen Cycle, than by the Choice of Land Cover Data, Glob. Change Biol., 9, 2893-2906, 2013. 
Joos, F. and Spahni, R.: Rates of change in natural and anthropogenic radiative forcing over the past 20,000 years, P. Natl. Acad. Sci. USA, 105, 1425-1430, 2008.

Kato, E., Kinoshita, T., Ito, A., Kawamiya, M., and Yamagata, Y.: Evaluation of spatially explicit emission scenario of land-use change and biomass burning using a process-based biogeochemical model, Journal of Land Use Science, 8, 104-122, 2013.

Keeling, C. D., Bacastow, R. B., Bainbridge, A. E., Ekdhal, C. A., Guenther, P. R., and Waterman, L. S.: Atmospheric carbon dioxide variations at Mauna Loa Observatory, Hawaii, Tellus, 28, 538-551, 1976.

Keeling, R. F., Manning, A. C., and Dubey, M. K.: The atmospheric signature of carbon capture and storage, Philos. T. Roy. Soc. A, 369, 2113-2132, 2011.

Khatiwala, S., Primeau, F., and Hall, T.: Reconstruction of the history of anthropogenic $\mathrm{CO}_{2}$ concentrations in the ocean, Nature, 462, 346-350, 2009.

Khatiwala, S., Tanhua, T., Mikaloff Fletcher, S., Gerber, M., Doney, S. C., Graven, H. D., Gruber, N., McKinley, G. A., Murata, A., Ríos, A. F., and Sabine, C. L.: Global ocean storage of anthropogenic carbon, Biogeosciences, 10, 2169-2191, doi:10.5194/bg-10-2169-2013, 2013.

Kirschke, S., Bousquet, P., Ciais, P., Saunois, M., Canadell, J. G., Dlugokencky, E. J., Bergamaschi, P., Bergmann, D., Blake, D. R., Bruhwiler, L., Cameron Smith, P., Castaldi, S., Chevallier, F., Feng, L., Fraser, A., Heimann, M., Hodson, E. L., Houweling, S., Josse, B., Fraser, P. J., Krummel, P. B., Lamarque, J., Langenfelds, R. L., Le Quéré, C., Naik, V., O’Doherty, S., Palmer, P. I., Pison, I., Plummer, D., Poulter, B., Prinn, R. G., Rigby, M., Ringeval, B., Santini, M., Schmidt, M., Shindell, D. T., Simpson, I. J., Spahni, R., Steele, L. P., Strode, S. A., Sudo, K., Szopa, S., van der Werf, G. R., Voulgarakis, A., van Weele, M., Weiss, R. F., Williams, J. E., and Zeng, G.: Three decades of global methane sources and sinks, Nat. Geosci., 6, 813-823, 2013.

Klein Goldewijk, K., Beusen, A., van Drecht, G., and de Vos, M.: The HYDE 3.1 spatially explicit database of human-induced global land-use change over the past 12,000 years, Global Ecol. Biogeogr., 20, 73-86, 2011.

Koven, C. D., Riley, W. J., Subin, Z. M., Tang, J. Y., Torn, M. S., Collins, W. D., Bonan, G. B., Lawrence, D. M., and Swenson, S. C.: The effect of vertically resolved soil biogeochemistry and alternate soil $\mathrm{C}$ and $\mathrm{N}$ models on C dynamics of CLM4, Biogeosciences, 10, 7109-7131, doi:10.5194/bg-10-7109-2013, 2013.

Krinner, G., Viovy, N., de Noblet, N., Ogée, J., Friedlingstein, P., Ciais, P., Sitch, S., Polcher, J., and Prentice, I. C.: A dynamic global vegetation model for studies of the coupled atmospherebiosphere system, Global Biogeochem. Cy., 19, 1-33, 2005.

Lamarque, J.-F., Bond, T. C., Eyring, V., Granier, C., Heil, A., Klimont, Z., Lee, D., Liousse, C., Mieville, A., Owen, B., Schultz, M. G., Shindell, D., Smith, S. J., Stehfest, E., Van Aardenne, J., Cooper, O. R., Kainuma, M., Mahowald, N., McConnell, J. R., Naik, V., Riahi, K., and van Vuuren, D. P.: Historical (1850-2000) gridded anthropogenic and biomass burning emissions of reactive gases and aerosols: methodology and application, Atmos. Chem. Phys., 10, 7017-7039, doi:10.5194/acp10-7017-2010, 2010.

Landschützer, P., Gruber, N., Bakker, D. C. E., and Schuster, U.: Recent variability of the global ocean carbon sink, Global Biogeochem. Cy., 28, 927-949, doi:10.1002/2014GB004853, 2014.
Le Quéré, C.: Closing the global budget for $\mathrm{CO}_{2}$ Global Change, 74, 28-31, 2009.

Le Quéré, C., Raupach, M. R., Canadell, J. G., Marland, G., Bopp, L., Ciais, P., Conway, T. J., Doney, S. C., Feely, R. A., Foster, P., Friedlingstein, P., Gurney, K., Houghton, R. A., House, J. I., Huntingford, C., Levy, P. E., Lomas, M. R., Majkut, J., Metzl, N., Ometto, J. P., Peters, G. P., Prentice, I. C., Randerson, J. T., Running, S. W., Sarmiento, J. L., Schuster, U., Sitch, S., Takahashi, T., Viovy, N., van der Werf, G. R., and Woodward, F. I.: Trends in the sources and sinks of carbon dioxide, Nat. Geosci., 2, 831-836, 2009.

Le Quéré, C., Andres, R. J., Boden, T., Conway, T., Houghton, R. A., House, J. I., Marland, G., Peters, G. P., van der Werf, G. R., Ahlström, A., Andrew, R. M., Bopp, L., Canadell, J. G., Ciais, P., Doney, S. C., Enright, C., Friedlingstein, P., Huntingford, C., Jain, A. K., Jourdain, C., Kato, E., Keeling, R. F., Klein Goldewijk, K., Levis, S., Levy, P., Lomas, M., Poulter, B., Raupach, M. R., Schwinger, J., Sitch, S., Stocker, B. D., Viovy, N., Zaehle, S., and Zeng, N.: The global carbon budget 1959-2011, Earth Syst. Sci. Data, 5, 165-185, doi:10.5194/essd-5-165-2013, 2013.

Le Quéré, C., Peters, G. P., Andres, R. J., Andrew, R. M., Boden, T. A., Ciais, P., Friedlingstein, P., Houghton, R. A., Marland, G., Moriarty, R., Sitch, S., Tans, P., Arneth, A., Arvanitis, A., Bakker, D. C. E., Bopp, L., Canadell, J. G., Chini, L. P., Doney, S. C., Harper, A., Harris, I., House, J. I., Jain, A. K., Jones, S. D., Kato, E., Keeling, R. F., Klein Goldewijk, K., Körtzinger, A., Koven, C., Lefèvre, N., Maignan, F., Omar, A., Ono, T., Park, G.-H., Pfeil, B., Poulter, B., Raupach, M. R., Regnier, P., Rödenbeck, C., Saito, S., Schwinger, J., Segschneider, J., Stocker, B. D., Takahashi, T., Tilbrook, B., van Heuven, S., Viovy, N., Wanninkhof, R., Wiltshire, A., and Zaehle, S.: Global carbon budget 2013, Earth Syst. Sci. Data, 6, 235-263, doi:10.5194/essd-6-2352014, 2014.

Manning, A. C. and Keeling, R. F.: Global oceanic and land biotic carbon sinks from the Scripps atmospheric oxygen flask sampling network, Tellus B, 58, 95-116, 2006.

Marland, G.: Uncertainties in accounting for $\mathrm{CO}_{2}$ from fossil fuels, J. Ind. Ecol., 12, 136-139, 2008.

Marland, G., Andres, R. J., Blasing, T. J., Boden, T. A., Broniak, C. T., Gregg, J. S., Losey, L. M., and Treanton, K.: Energy, industry and waste management activities: An introduction to $\mathrm{CO}_{2}$ emissions from fossil fuels, in: A report by the US Climate Change Science Program and the Subcommittee on Global Change Research, in: The First State of the Carbon Cycle Report (SOCCR): The North American Carbon Budget and Implications for the Global Carbon Cycle, edited by: King, A. W., Dilling, L., Zimmerman, G. P., Fairman, D. M., Houghton, R. A., Marland, G., Rose, A. Z., and Wilbanks, T. J., Asheville, NC, 2007.

Marland, G., Hamal, K., and Jonas, M.: How Uncertain Are Estimates of $\mathrm{CO}_{2}$ Emissions?, J. Ind. Ecol., 13, 4-7, 2009.

Masarie, K. A. and Tans, P. P.: Extension and integratino of atmospheric carbon dioxide data into a globally consistent measurement record, J. Geophys. Res.-Atmos., 100, 11593-11610, 1995.

McNeil, B. I., Matear, R. J., Key, R. M., Bullister, J. L., and Sarmiento, J. L.: Anthropogenic $\mathrm{CO}_{2}$ uptake by the ocean based on the global chlorofluorocarbon data set, Science, 299, 235239, 2003.

Mikaloff Fletcher, S. E., Gruber, N., Jacobson, A. R., Doney, S. C., Dutkiewicz, S., Gerber, M., Follows, M., Joos, F., Lindsay, 
K., Menemenlis, D., Mouchet, A., Müller, S. A., and Sarmiento, J. L.: Inverse estimates of anthropogenic $\mathrm{CO}_{2}$ uptake, transport, and storage by the oceans, Global Biogeochem. Cy., 20, GB2002, doi:10.1029/2005GB002530, 2006.

Narayanan, B., Aguiar, A., and McDougall, R.: Global Trade, Assistance, and Production: The GTAP 8 Data Base, https: //www.gtap.agecon.purdue.edu/databases/v8/default.asp, last access: Septemper 2013.

NOAA/ESRL: NOAA/ESRL calculation of global means, http:// www.esrl.noaa.gov/gmd/ccgg/about/global_means.html, last access: 8 August 2014.

Oke, P. R., Griffin, D. A., Schiller, A., Matear, R. J., Fiedler, R., Mansbridge, J., Lenton, A., Cahill, M., Chamberlain, M. A., and Ridgway, K.: Evaluation of a near-global eddy-resolving ocean model, Geosci. Model Dev., 6, 591-615, doi:10.5194/gmd-6591-2013, 2013.

Oleson, K., Lawrence, D., Bonan, G., Drewniak, B., Huang, M., Koven, C., Levis, S., Li, F., Riley, W., Subin, Z., Swenson, S., Thornton, P., Bozbiyik, A., Fisher, R., Heald, C., Kluzek, E., Lamarque, J., Lawrence, P., Leung, L., Lipscomb, W., Muszala, S., Ricciuto, D., Sacks, W., Tang, J., and Yang, Z.: Technical Description of version 4.5 of the Community Land Model (CLM), NCAR, National Center for Atmospheric Research (NCAR) Boulder, Colorado, 2013.

Park, G. H., Wanninkhof, R., Doney, S. C., Takahashi, T., Lee, K., Feely, R. A., Sabine, C. L., Trinanes, J., and Lima, I. D.: Variability of global net sea-air $\mathrm{CO}_{2}$ fluxes over the last three decades using empirical relationships, Tellus B, 62, 352-368, 2010.

Peters, G. P. and Hertwich, E. G.: Post-Kyoto Greenhouse Gas Inventories: Production versus Consumption, Climatic Change, 86, 51-66, 2008.

Peters, W., Krol, M. C., Van Der Werf, G. R., Houweling, S., Jones, C. D., Hughes, J., Schaefer, K., Masarie, K. A., Jacobson, A. R., Miller, J. B., Cho, C. H., Ramonet, M., Schmidt, M., Ciattaglia, L., Apadula, F., Heltai, D., Meinhardt, F., Di Sarra, A. G., Piacentino, S., Sferlazzo, D., Aalto, T., Hatakka, J., Ström, J., Haszpra, L., Meijer, H. A. J., Van Der Laan, S., Neubert, R. E. M., Jordan, A., Rodó, X., Morguí, J.-A., Vermeulen, A. T., Popa, E., Rozanski, K., Zimnoch, M., Manning, A. C., Leuenberger, M., Uglietti, C., Dolman, A. J., Ciais, P., Heimann, M., and Tans, P. P.: Seven years of recent European net terrestrial carbon dioxide exchange constrained by atmospheric observations, Glob. Change Biol., 16, 1317-1337, 2010.

Peters, G. P., Andrew, R., and Lennos, J.: Constructing a multiregional input-output table using the GTAP database, Economic Systems Research, 23, 131-152, 2011 a.

Peters, G. P., Minx, J. C., Weber, C. L., and Edenhofer, O.: Growth in emission transfers via international trade from 1990 to 2008, P. Natl. Acad. Sci. USA, 108, 8903-8908, 2011b.

Peters, G. P., Davis, S. J., and Andrew, R.: A synthesis of carbon in international trade, Biogeosciences, 9, 3247-3276, doi:10.5194/bg-9-3247-2012, 2012a.

Peters, G. P., Marland, G., Le Quéré, C., Boden, T. A., Canadell, J. G., and Raupach, M. R.: Correspondence: Rapid growth in $\mathrm{CO}_{2}$ emissions after the 2008-2009 global financial crisis, Nature Clim. Change, 2, 2-4, $2012 \mathrm{~b}$.

Peters, G. P., Andrew, R. M., Boden, T., Canadell, J. G., Ciais, P., Le Quéré, C., Marland, G., Raupach, M. R., and Wilson, C.:
The challenge to keep global warming below $2{ }^{\circ} \mathrm{C}$, Nature Clim. Change, 3, 4-6, 2013.

Peylin, P., Law, R. M., Gurney, K. R., Chevallier, F., Jacobson, A. R., Maki, T., Niwa, Y., Patra, P. K., Peters, W., Rayner, P. J., Rödenbeck, C., van der Laan-Luijkx, I. T., and Zhang, X.: Global atmospheric carbon budget: results from an ensemble of atmospheric $\mathrm{CO}_{2}$ inversions, Biogeosciences, 10, 6699-6720, doi:10.5194/bg-10-6699-2013, 2013.

Pfeil, B., Olsen, A., Bakker, D. C. E., Hankin, S., Koyuk, H., Kozyr, A., Malczyk, J., Manke, A., Metzl, N., Sabine, C. L., Akl, J., Alin, S. R., Bates, N., Bellerby, R. G. J., Borges, A., Boutin, J., Brown, P. J., Cai, W.-J., Chavez, F. P., Chen, A., Cosca, C., Fassbender, A. J., Feely, R. A., González-Dávila, M., Goyet, C., Hales, B., Hardman-Mountford, N., Heinze, C., Hood, M., Hoppema, M., Hunt, C. W., Hydes, D., Ishii, M., Johannessen, T., Jones, S. D., Key, R. M., Körtzinger, A., Landschützer, P., Lauvset, S. K., Lefèvre, N., Lenton, A., Lourantou, A., Merlivat, L., Midorikawa, T., Mintrop, L., Miyazaki, C., Murata, A., Nakadate, A., Nakano, Y., Nakaoka, S., Nojiri, Y., Omar, A. M., Padin, X. A., Park, G.-H., Paterson, K., Perez, F. F., Pierrot, D., Poisson, A., Ríos, A. F., Santana-Casiano, J. M., Salisbury, J., Sarma, V. V. S. S., Schlitzer, R., Schneider, B., Schuster, U., Sieger, R., Skjelvan, I., Steinhoff, T., Suzuki, T., Takahashi, T., Tedesco, K., Telszewski, M., Thomas, H., Tilbrook, B., Tjiputra, J., Vandemark, D., Veness, T., Wanninkhof, R., Watson, A. J., Weiss, R., Wong, C. S., and Yoshikawa-Inoue, H.: A uniform, quality controlled Surface Ocean $\mathrm{CO}_{2}$ Atlas (SOCAT), Earth Syst. Sci. Data, 5, 125-143, doi:10.5194/essd-5-125-2013, 2013.

Pongratz, J., Reick, C. H., Raddatz, T., and Claussen, M.: Effects of anthropogenic land cover change on the carbon cycle of the last millennium, Global Biogeochem. Cy., 23, GB4001, doi:10.1029/2009gb003488, 2009.

Pongratz, J., Reick, C. H., Houghton, R. A., and House, J. I.: Terminology as a key uncertainty in net land use and land cover change carbon flux estimates, Earth Syst. Dynam., 5, 177-195, doi:10.5194/esd-5-177-2014, 2014.

Poulter, B., Frank, D., Ciais, P., Myneni, R. B., Andela, N., Bi, J., Broquet, G., Canadell, J. G., Chevallier, F., Liu, Y. Y., Running, S. W., Sitch, S., and van der Werf, G. R.: Contribution of semiarid ecosystems to interannual variability of the global carbon cycle, Nature, 509, 600-603, 2014.

Prather, M. J., Holmes, C. D., and Hsu, J.: Reactive greenhouse gas scenarios: Systematic exploration of uncertainties and the role of atmospheric chemistry, Geophys. Res. Lett., 39, L09803, doi:10.1029/2012GL051440, 2012.

Prentice, I. C., Farquhar, G. D., Fasham, M. J. R., Goulden, M. L., Heimann, M., Jaramillo, V. J., Kheshgi, H. S., Le Quéré, C., Scholes, R. J., and Wallace, D. W. R.: The Carbon Cycle and Atmospheric Carbon Dioxide, in: Climate Change 2001: The Scientific Basis. Contribution of Working Group I to the Third Assessment Report of the Intergovernmental Panel on Climate Change, edited by: Houghton, J. T., Ding, Y., Griggs, D. J., Noguer, M., van der Linden, P. J., Dai, X., Maskell, K., and Johnson, C. A., Cambridge University Press, Cambridge, United Kingdom and New York, NY, USA., 2001.

Randerson, J., Chen, Y., van der Werf, G. R., Rogers, B. M., and Morton, D. C.: Global burned area and biomass burning emissions from small fires, J. Geophys. Res.-Biogeo., 117, G04012, doi:10.1029/2012JG002128, 2012. 
Raupach, M. R., Marland, G., Ciais, P., Le Quéré, C., Canadell, J. G., Klepper, G., and Field, C. B.: Global and regional drivers of accelerating $\mathrm{CO}_{2}$ emissions, P. Natl. Acad. Sci. USA, 104, 10288-10293, 2007.

Regnier, P., Friedlingstein, P., Ciais, P., Mackenzie, F. T., Gruber, N., Janssens, I. A., Laruelle, G. G., Lauerwald, R., Luyssaert, S., Andersson, A. J., Arndt, S., Arnosti, C., Borges, A. V., Dale, A. W., Gallego-Sala, A., Goddéris, Y., Goossens, N., Hartmann, J., Heinze, C., Ilyina, T., Joos, F., La Rowe, D. E., Leifeld, J., Meysman, F. J. R., Munhoven, G., Raymond, P. A., Spahni, R., Suntharalingam, P., and Thullner, M.: Anthropogenic perturbation of the carbon fluxes from land to ocean, Nat. Geosci., 6, 597-607, 2013.

Rhein, M., Rintoul, S. R., Aoki, S., Campos, E., Chambers, D., Feely, R. A., Gulev, S., Johnson, G. C., Josey, S. A., Kostianoy, A., Mauritzen, C., Roemmich, D., Talley, L. D., and Wang, F.: Chapter 3: Observations: Ocean. in: Climate Change 2013 The Physical Science Basis, Cambridge University Press, 2013.

Rödenbeck, C.: Estimating $\mathrm{CO}_{2}$ sources and sinks from atmospheric mixing ratio measurements using a global inversion of atmospheric transport, Max Plank Institute, MPI-BGC, 2005.

Rödenbeck, C., Houweling, S., Gloor, M., and Heimann, M.: $\mathrm{CO}_{2}$ flux history 1982-2001 inferred from atmospheric data using a global inversion of atmospheric transport, Atmos. Chem. Phys., 3, 1919-1964, doi:10.5194/acp-3-1919-2003, 2003.

Rödenbeck, C., Keeling, R. F., Bakker, D. C. E., Metzl, N., Olsen, A., Sabine, C., and Heimann, M.: Global surface-ocean $p \mathrm{CO}_{2}$ and sea-air $\mathrm{CO}_{2}$ flux variability from an observationdriven ocean mixed-layer scheme, Ocean Sci., 9, 193-216, doi:10.5194/os-9-193-2013, 2013.

Rödenbeck, C., Bakker, D. C. E., Metzl, N., Olsen, A., Sabine, C., Cassar, N., Reum, F., Keeling, R. F., and Heimann, M.: Interannual sea-air $\mathrm{CO}_{2}$ flux variability from an observationdriven ocean mixed-layer scheme, Biogeosciences, 11, 45994613, doi:10.5194/bg-11-4599-2014, 2014.

Rypdal, K., Paciomik, N., Eggleston, S., Goodwin, J., Irving, W., Penman, J., and Woodfield, M.: Chapter 1 Introduction to the 2006 Guidelines, in: 2006 IPCC Guidelines for National Greenhouse Gas Inventories, edited by: Eggleston, S., Buendia, L., Miwa, K., Ngara, T., and Tanabe, K., Institute for Global Environmental Strategies (IGES), Hayama, Kanagawa, Japan, 2006.

Schimel, D., Alves, D., Enting, I., Heimann, M., Joos, F., Raynaud, D., Wigley, T., Prater, M., Derwent, R., Ehhalt, D., Fraser, P., Sanhueza, E., Zhou, X., Jonas, P., Charlson, R., Rodhe, H., Sadasivan, S., Shine, K. P., Fouquart, Y., Ramaswamy, V., Solomon, S., Srinivasan, J., Albritton, D., Derwent, R., Isaksen, I., Lal, M., and Wuebbles, D.: Radiative Forcing of Climate Change, in: Climate Change 1995 The Science of Climate Change. Contribution of Working Group I to the Second Assessment Report of the Intergovernmental Panel on Climate Change, edited by: Houghton, J. T., Meira Rilho, L. G., Callander, B. A., Harris, N., Kattenberg, A., and Maskell, K., Cambridge University Press, Cambridge, United Kingdom and New York, NY, USA, 1995.

Scripps: The Keeling Curve, available at: http://keelingcurve.ucsd. edu/, last access: 7 November 2013.

Séférian, R., Bopp, L., Gehlen, M., Orr, J., Ethé, C., Cadule, P., Aumont, O., Salas y Mélia, D., Voldoire, A., and Madec, G.: Skill assessment of three earth system models with common marine biogeochemistry, Clim. Dynam., 40, 2549-2573, 2013.
Shevliakova, E., Pacala, S., Malyshev, S., Hurtt, G., Milly, P., Caspersen, J., Sentman, L., Fisk, J., Wirth, C., and Crevoisier, C.: Carbon cycling under 300 years of land use change: Importance of the secondary vegetation sink, Global Biogeochem. Cy., 23, GB2022, doi:10.1029/2007GB003176, 2009.

Sitch, S., Smith, B., Prentice, I. C., Arneth, A., Bondeau, A., Cramer, W., Kaplan, J. O., Levis, S., Lucht, W., Sykes, M. T., Thonicke, K., and Venevsky, S.: Evaluation of ecosystem dynamics, plant geography and terrestrial carbon cycling in the LPJ dynamic global vegetation model, Glob. Change Biol., 9, 161-185, 2003.

Smith, B., Prentice, I. C., and Sykes, M. T.: Representation of vegetation dynamics in the modelling of terrestiral ecosystems: comparing two contrasting approaches withing European climate space, Global Ecol. Biogeogr., 10, 621-637, doi:10.1046/j.1466822X.2001.t01-1-00256.x, 2001.

Stephens, B. B., Gurney, K. R., Tans, P. P., Sweeney, C., Peters, W., Bruhwiler, L., Ciais, P., Ramonet, M., Bousquet, P., Nakazawa, T., Aoki, S., Machida, T., Inoue, G., Vinnichenko, N., Lloyd, J., Jordan, A., Heimann, M., Shibistova, O., Langenfelds, R. L., Steele, L. P., Francey, R. J., and Denning, A. S.: Weak Northern and Strong Tropical Land Carbon Uptake from Vertical Profiles of Atmospheric $\mathrm{CO}_{2}$, Science, 316, 1732-1735, 2007.

Stocker, B. D., Roth, R., Joos, F., Spahni, R., Steinacher, M., Zaehle, S., Bouwman, L., and Prentice, I. C.: Multiple greenhouse-gas feedbacks from the land biosphere under future climate change scenarios, Nature Clim. Change, 3, 666-672, $2013 \mathrm{a}$.

Stocker, T., Qin, D., and Platner, G.-K.: Climate Change 2013 The Physical Science Basis, Cambridge University Press, 2013b.

Sweeney, C., Gloor, E., Jacobson, A. R., Key, R. M., McKinley, G., Sarmiento, J. L., and Wanninkhof, R.: Constraining global air-sea gas exchange for $\mathrm{CO}_{2}$ with recent bomb ${ }^{14} \mathrm{C}$ measurements, Global Biogeochem. Cy., 21, GB2015, doi:10.1029/2006GB002784, 2007.

Tans, P. and Keeling, R. F.: Trends in atmospheric carbon dioxide, National Oceanic \& Atmospheric Administration, Earth System Research Laboratory (NOAA/ESRL) \& Scripps Institution of Oceanography, available at: http://www.esrl.noaa.gov/gmd/ ccgg/trends/ and http://scrippsco2.ucsd.edu/, last access: $8 \mathrm{Au}-$ gust 2014.

Tjiputra, J. F., Roelandt, C., Bentsen, M., Lawrence, D. M., Lorentzen, T., Schwinger, J., Seland, Ø., and Heinze, C.: Evaluation of the carbon cycle components in the Norwegian Earth System Model (NorESM), Geosci. Model Dev., 6, 301-325, doi:10.5194/gmd-6-301-2013, 2013.

UN: United Nations Statistics Division: Energy Statistics, United Nations Statistics Division: Energy Statistics, available at: http: //unstats.un.org/unsd/energy/, last access: August 2013a.

UN: United Nations Statistics Division: Industry Statistics, United Nations Statistics Division: Industry Statistics, http://unstats.un. org/unsd/industry/default.asp, last access: August 2013b.

UN: United Nations Statistics Division: National Accounts Main Aggregates Database, United Nations Statistics Division: National Accounts Main Aggregates Database, available at: http: //unstats.un.org/unsd/snaama/Introduction.asp, last access: $8 \mathrm{Au}-$ gust 2014.

U.S. Geological Survey: Mineral Commodities Summaries, US Geological Survey, 2012.

USGS: Mineral Commodities Summaries: Cement, USGS, 2014. 
van der Werf, G. R., Dempewolf, J., Trigg, S. N., Randerson, J. T., Kasibhatla, P., Giglio, L., Murdiyarso, D., Peters, W., Morton, D. C., Collatz, G. J., Dolman, A. J., and DeFries, R. S.: Climate regulation of fire emissions and deforestation in equatorial Asia, P. Natl. Acad. Sci. USA, 15, 20350-20355, 2008.

van der Werf, G. R., Randerson, J. T., Giglio, L., Collatz, G. J., Mu, M., Kasibhatla, P. S., Morton, D. C., DeFries, R. S., Jin, Y., and van Leeuwen, T. T.: Global fire emissions and the contribution of deforestation, savanna, forest, agricultural, and peat fires (19972009), Atmos. Chem. Phys., 10, 11707-11735, doi:10.5194/acp10-11707-2010, 2010.

van Minnen, J. G., Goldewijk, K. K., Stehfest, E., Eickhout, B., van Drecht, G., and Leemans, R.: The importance of three centuries of land-use change for the global and regional terrestrial carbon cycle, Climatic Change, 97, 123-144, 2009.

van Oss, H. G.: Cement, US Geological Survey, June, 2013.

Wang, Y. P., Law, R. M., and Pak, B.: A global model of carbon, nitrogen and phosphorus cycles for the terrestrial biosphere, Biogeosciences, 7, 2261-2282, doi:10.5194/bg-7-2261-2010, 2010.

Wang, Y. P., Kowalczyk, E., Leuning, R., Abramowitz, G., Raupach, M. R., Pak, B., van Gorsel, E., and Luhar, A.: Diagnosing errors in a land surface model (CABLE) in the time and frequency domains, J. Geophys. Res., 116, G01034, doi:10.1029/2010JG001385, 2011.

Wanninkhof, R., Park, G.-H., Takahashi, T., Sweeney, C., Feely, R., Nojiri, Y., Gruber, N., Doney, S. C., McKinley, G. A., Lenton, A., Le Quéré, C., Heinze, C., Schwinger, J., Graven, H., and Khatiwala, S.: Global ocean carbon uptake: magnitude, variability and trends, Biogeosciences, 10, 1983-2000, doi:10.5194/bg10-1983-2013, 2013.
Watson, R. T., Rodhe, H., Oeschger, H., and Siegenthaler, U.: Greenhouse Gases and Aerosols, in: Climate Change: The IPCC Scientific Assessment. Intergovernmental Panel on Climate Change (IPCC), edited by: Houghton, J. T., Jenkins, G. J., and Ephraums, J. J., Cambridge University Press, Cambridge, 1990.

Zaehle, S., Ciais, P., Friend, A. D., and Prieur, V.: Carbon benefits of anthropogenic reactive nitrogen offset by nitrous oxide emissions, Nat. Geosci., 4, 601-605, 2011.

Zeng, J., Nojiri, Y., Landschützer, P., Telszewski, M., and Nakaoka, S.: A global surface ocean $f \mathrm{CO}_{2}$ climatology based on a feedforward neural network, J. Atmos. Ocean Tech., 31, 1838-1849, 2014.

Zeng, N., Mariotti, A., and Wetzel, P.: Terrestrial mechanisms of interannual $\mathrm{CO}_{2}$ variability, Global Biogeochem. Cy., 19, GB1016, doi:10.1029/2004GB002273, 2005.

Zhang, Q., Pitman, A. J., Wang, Y. P., Dai, Y. J., and Lawrence, P. J.: The impact of nitrogen and phosphorous limitation on the estimated terrestrial carbon balance and warming of land use change over the last 156 yr, Earth Syst. Dynam., 4, 333-345, doi:10.5194/esd-4-333-2013, 2013. 